\title{
A review of the ever increasing threat to European crayfish from non-indigenous crayfish species
}

\author{
D.M. Holdich ${ }^{(1)}$, J.D. Reynolds ${ }^{(2)}$, C. Souty-Grosset ${ }^{(3)}$, P.J. Sibley ${ }^{(4)}$ \\ Received October 27, 2009 / Reçu le 27 octobre 2009 \\ Revised November 23, 2009 / Révisé le 23 novembre 2009 \\ Accepted December 15, 2009 / Accepté le 15 décembre 2009
}

Key-words:

Europe, crayfish, indigenous, non-indigenous, plague, arks, model

\section{ABSTRACT}

Non-indigenous crayfish species (NICS) in Europe now outnumber indigenous crayfish species (ICS) 2:1, and it has been predicted that they may dominate completely in the next few decades unless something is done to protect them. Of the ten NICS introduced at least nine have become established in areas occupied by four of the five ICS. A decline in stocks of ICS has been recorded in many countries in the face of increasing populations of NICS. Most European countries retain at least one ICS but all are under threat from habitat loss, deteriorating water quality, overfishing, climate change, and most importantly from NICS and crayfish plague. The threat to ICS is so great in some countries that "ark" sanctuary sites are being established.

The three most widely-spread NICS are the North American species: Pacifastacus leniusculus, Orconectes limosus and Procambarus clarkii. These can be considered as "Old NICS", which were introduced before 1975, compared with the "New NICS", which were introduced after 1980, such as the North American species: Orconectes immunis, Orconectes juvenilis, Orconectes virilis, Procambarus sp. and Procambarus acutus; and the Australian species: Cherax destructor and Cherax quadricarinatus, all of which have much narrower ranges in Europe. The North American species are potentially capable of acting as vectors of crayfish plague. Outbreaks of this disease occur regularly where there are high concentrations of vectors.

In addition to the NICS currently established in the wild, a further threat exists through the aquarium trade, where many American and Australian species are available via the internet and in aquarist centres. Owners of such species may discard them into the freshwater environment when they grow too big as with some Cherax spp. and Orconectes spp., or multiply too frequently as with Procambarus sp. (a parthenogenetic species). A conceptual model is presented as a possible way forward for protecting the future survival of ICS in Europe.

(1) Crayfish Survey \& Research, Peak Ecology Ltd., Lumford Mill, Riverside Business Park, Bakewell, Derbyshire DE45 1GS, UK, david.holdich@nt/world.com

(2) Trinity College, Dublin University, Republic of Ireland, jrynolds@tcd.ie

(3) Université de Poitiers, 'Écologie, Évolution Symbiose', UMR CNRS 6556, 40 avenue du Recteur Pineau, 86022 Poitiers Cedex, France, catherine.souty@univ-poitiers.fr

(4) Environment Agency, South West Region, Wessex Area, Analysis \& Reporting, Rivers House, East Quay, Bridgwater, Somerset, TA6 4YS, UK, peter.sibley@environment-agency.gov.uk 


\section{RÉSUMÉ}

Une mise à jour sur la menace perpétuelle des écrevisses non indigènes pour les écrevisses européennes

\author{
Mots-clés : \\ Europe, \\ écrevisse, \\ indigène, \\ non indigène, \\ peste de \\ l'écrevisse, \\ sanctuaire, \\ modèle
}

Le nombre d'espèces d'écrevisses non indigènes (NICS) présentes en Europe dépasse maintenant celui des espèces indigènes (ICS) 2:1, et il est même prédit leur dominance complète si rien n'est fait pour protéger les espèces indigènes. Sur les dix espèces introduites (NICS), au moins neuf sont bien établies sur les territoires occupés par quatre des cinq espèces indigènes (ICS). Un déclin des stocks indigènes a été observé dans beaucoup de pays face au nombre croissant de populations non indigènes. La plupart des pays européens héberge au moins une espèce indigène mais toutes sont en danger à cause de la perte de l'habitat, la détérioration de la qualité de l'eau, la pêche intensive, le changement climatique et, plus important, la peste apportée par les écrevisses non indigènes. Dans certains pays, la menace est si grande pour les espèces indigènes que des sanctuaires («ark sites ») ont été établis pour leur protection.

Les trois espèces non indigènes (NICS) les plus répandues proviennent d'Amérique du nord : Pacifastacus leniusculus, Orconectes limosus et Procambarus clarkii. Elles peuvent être considérées comme anciennes («Old NICS »), car introduites avant 1975, en comparaison avec les plus récemment introduites («New NICS »), c'est-à-dire après 1980, comme les espèces d'Amérique du nord : Orconectes immunis, Orconectes juvenilis, Orconectes virilis, Procambarus sp. et Procambarus acutus; ainsi que les espèces australiennes : Cherax destructor et Cherax quadricarinatus, toutes ayant une aire de répartition plus limitée en Europe. Les espèces nord américaines sont potentiellement capables d'agir comme vecteurs de la peste de l'écrevisse. Les épidémies de peste se déclarent régulièrement là où il y a une grande concentration de vecteurs.

En plus des espèces non indigènes couramment établies dans la nature, une menace supplémentaire existe à cause du marché en aquariophilie car la plupart des espèces américaines et australiennes sont disponibles sur internet et dans les magasins. Les propriétaires de telles espèces peuvent les relâcher dans les eaux douces quand elles ont une taille trop grande comme Cherax spp. et Orconectes spp., ou quand elles se reproduisent trop fréquemment comme Procambarus sp. (espèce parthénogénétique).

Un modèle est proposé comme moyen possible de protéger plus efficacement les écrevisses indigènes dans les années à venir.

\section{INTRODUCTION}

It has been estimated that between one-third and one-half of the world's crayfish species are threatened with population decline or extinction (Taylor, 2002). The greatest threat to crayfish biodiversity is from non-indigenous crayfish introduced for harvesting for food or unintentionally as unused bait or unwanted aquarium pets (Holdich, 1999; Taugbøl and Skurdal, 1999; Lodge et al., 2000; Gherardi, 2007; Taylor et al., 2007). In North America indigenous crayfish species (ICS) have been displaced by non-indigenous crayfish species (NICS) through direct competition (Taylor, 2002). This has also been the case in Europe, but the additional effect of crayfish plague has meant that the devastation amongst the small number of indigenous species has been far greater.

By comparison with North America and Australia Europe has an impoverished crayfish fauna (Taylor, 2002). The five (or six, see below) ICS in Europe are under threat from a variety of factors including habitat loss, deteriorating water quality, overfishing and climate change, as well as NICS and crayfish plague. In 1996, Astacus astacus (L.), Austropotamobius pallipes (Lereboullet) and Austropotamobius torrentium (Schrank) were assessed as vulnerable using criterion B2bce+3bcd of the IUCN Categories and Criteria (version 2.3) (Baillie and Groombridge, 1996). Revisions to these 1996 assessments are currently underway using 
the updated version of the Categories and Criteria, Version 3.1 (IUCN, 2001). Taugbøl and Skurdal (1999) predicted that if plans were not put in place, then in 100 years time it might be that all watersheds suitable for crayfish in Europe are occupied by NICS, and all ICS are critically endangered and survive in a few protected localities.

Perhaps uniquely amongst animals introduced into Europe's inland waters, crayfish have a $90 \%$ success record, i.e. so far ten NICS have been introduced and at least nine have become established, although other introduced crustacean groups such as North American and Ponto-Caspian amphipods and mysids may well be equally as successful in Western Europe (Holdich and Pöckl, 2007). The achievement of the NICS in Europe is largely down to their robust nature coupled with fast individual and population growth, high fecundity and invasive capabilities (Lindqvist and Huner, 1999). North American crayfish are also immune to the effects of crayfish plague unless put under stress (Cerenius and Söderhäll, 1992). The pros and cons of introducing NICS into Europe have been reviewed by Ackefors (1999), Holdich (1999) and Westman (2002). Tricarico et al. (2010) have developed "The Freshwater Invertebrate Invasiveness Scoring Kit (FI-ISK)" as a screening tool for identifying potentially invasive freshwater invertebrates. They deployed FI-ISK to assess the risk that a wide range of crayfish species belonging to the families Astacidae, Cambaridae and Parastacidae might pose to the Italian freshwater environment. They found that $P$. clarkii and $P$. leniusculus had high risk scores, as did $O$. limosus and $C$. destructor, whilst $A$. leptodactylus, $C$. quadricarinatus and Procambarus sp. were considered a medium risk. They concluded that FI-ISK will provide a useful and viable tool to aid decision- and policy-makers in assessing and classifying freshwater invertebrates according to their potential invasiveness. This has relevance to the 2007 European Union regulation regarding the introduction of alien species for aquaculture and related activities: Council Regulation No 708/2007 (28.6.2007 Official Journal of the European Union L 168/1-17).

Eight of the NICS established in Europe originate from North America and two from Australia. Three of the North American NICS have been introduced into Europe to supplement crayfish stocks, as many populations of ICS have been devastated by crayfish plague since the mid-19th century, and for aquaculture, i.e. Orconectes limosus (Rafinesque) to the German/Polish border in 1890 (Borne, 1906), Pacifastacus leniusculus (Dana) to Sweden in 1959 (Abrahamsson, 1973) and Procambarus clarkii (Girard) to Spain in 1973 (HabsburgoLorena, 1979). These can be considered as "Old NICS", having been introduced before 1975, compared to "New NICS", which have been introduced since 1980, mainly through the aquarium trade and for aquaculture. In general "Old NICS" are very difficult to control and virtually impossible to eliminate once they have become established (Holdich et al., 1999; Peay et al., 2006; Aquiloni et al., 2009), although when they are found in a new area it may be possible to eliminate them before they become too well established, and the same applies to "New NICS".

In this paper the authors update distributional information and discuss the status of ICS and NICS in Europe from information in the recent literature and from personal contacts made during 2008 and 2009. We also examine the recent impact of NICS and crayfish plague on ICS in selected countries in Europe. The situation in South-west England is used to show how the balance can shift from one dominated by ICS to one dominated by NICS in a few decades. A slightly modified version of a conceptual model first introduced by Taugbøl and Skurdal (1999) is discussed as a way forward for protecting the future survival of ICS in Europe.

\section{CRAYFISH PLAGUE}

Crayfish plague, caused by the fungus-like organism Aphanomyces astaci Schikora, is listed in the top 100 of the "World's Worst" invaders by the International Union for Conservation of Nature (IUCN) (Lowe et al., 2000). Aphanomyces astaci belongs to the Saprolegniales (Oomycetes); the many species of Aphanomyces (30-40) can be either plant or animal parasites or saprophytes and are highly specialized, with narrow host ranges (Diéguez-Uribeondo et al., 2009). Unestam $(1969,1972)$ showed that North American crayfish species are vectors 
of the disease and that Asiatic, Australasian and European crayfish were highly susceptible to its effects. Unestam and Weiss (1970) isolated $A$. astaci from $P$. leniusculus from the Sacramento River and Lake Tahoe in western North America thus proving that the pathogen originated from North America. The pathogen lives in melanized areas of the cuticle and is spread by asexual swimming zoospores, which serve as the infective units. Water is the best medium for transmission of spores, but any item that has been in contact with water containing spores can also transmit them; the spores can survive for up to 16 days under humid and cool conditions; high magnesium and low calcium levels in water are unfavourable for the spores (Oidtmann, 2000). Unestam (1969) found that North American crayfish species are highly resistant to infection by $A$. astaci, suggesting that they are largely immune to its effects and live in a balanced host-parasite relationship with the parasite probably as a result of coevolution. However, Cerenius and Söderhäll (1992) found that the presence of the pathogen in $P$. leniusculus means that its immune system is constantly alerted and the animal is under permanent stress. If it then becomes additionally stressed by other parasites or environmental conditions it can die rapidly from crayfish plague. This can cause high mortalites in both aquaculture and the wild, and may explain some of the mortalities in $P$. leniusculus populations in Sweden (Edsman, 2009, pers. comm.) and Finland (Pursiainen, 2009, pers. comm.), as well in other North American NICS elsewhere. Cerenius and Söderhäll (1992) stress that the absence of melanised patches in $P$. leniusculus is not an indication that it is free from crayfish plague.

Although North American crayfish have the potential to carry crayfish plague, of the $360+$ species living there (Taylor et al., 2007) only three as far as is known have been tested and shown to be vectors of the disease as NICS in Europe (Diéguez-Uribeondo, 2006b), i.e. P. leniusculus (Unestam and Weiss, 1970), O. limosus (Vey et al., 1983) and P. clarkii (DiéguezUribeondo and Söderhäll, 1993). The spread of these species in Europe in the 19th, 20th and 21 st century is closely associated with the spread of crayfish plague.

There have been a number of reviews of the history of crayfish plague in Europe, i.e. Alderman and Polglase (1988), Holdich et al. (1995), Alderman (1996), Holdich (2003) and DiéguezUribeondo (2006b), and mention is made below of just the more recent outbreaks for individual countries.

\section{CRAYFISH IN EUROPE}

\section{$>$ BACKGROUND}

The information given below updates some of the distributional data given in Holdich (2002, 2003), Holdich et al. (2006), Machino and Holdich (2006) and Pöckl et al. (2006), and has been derived from the recent literature and personal contacts with crayfish workers in Europe during 2008-2009. Recent updates on the situation in Austria (Füreder et al., 2009), Eastern Europe (Maguire, 2009), Germany (Schulz et al., 2009), Italy (Gherardi et al., 2009) and Switzerland (Stucki et al., 2009) have been published in German by Füreder (2009).

With the exception of Portugal, where $A$. pallipes has most likely been eliminated (Machino and Holdich, 2006), most European territories retain at least one ICS, although some have probably never had any indigenous crayfish species, e.g. Cyprus, Malta, Monaco, as well as large offshore island groups such as the Azores, Balearics, Canaries, Channel Islands (British Crown dependency), Greek and Italian islands and Madeira. Some islands in the Baltic Sea have populations of $A$. astacus, but these have been introduced. Of those countries possessing at least one ICS, only Andorra, Ireland and Liechtenstein in the west and, as far as is known, Albania, Armenia, Azerbaijan, Bosnia-Herzegovina, Bulgaria, Estonia, European Russia, European Turkey, Georgia, Kazakhstan, Macedonia, Moldova, Montenegro and the Ukraine in the east are currently free from NICS. Attempts have been made to introduce NICS into Russia but these have been unsuccessful (Holdich, 2002; Machino and Holdich, 2006), harvestable stocks of $A$. astacus are particularly prevalent in the north-west (Susloparova and Mitskevich, 2009). Note that Azerbaijan, Georgia, Kazakhstan, Russia and Turkey are 
considered part of both Europe and Asia; and Armenia and Cyprus are sociopolitical European countries. Table I summarizes the occurrences of ICS and NICS in European countries and Table II quantifies this for each country.

It can be seen from Table II that some countries have a relatively high number of crayfish species, although some European ICS may well have been introduced recently, particularly A. leptodactylus. Austria is known to have four European ICS and three NICS, England - one ICS and six NICS, France - four ICS and five NICS, Germany - four ICS and five NICS, Italy four ICS and five NICS, Netherlands - two ICS and six NICS, and Switzerland - four ICS and three NICS. However, when assessing the indigenous and conservation status of ICS the following ruling from the IUCN should be noted:

"To decide whether an introduced species is now considered naturalized to a region for the purposes of a Red Data Book, IUCN recommends that a preset year or event may be used (IUCN, 2003). For assessments of species in Europe, IUCN uses a cut-off date of 1500 and if a species existed in a country since that date it is considered indigenous for the purposes of the Red List assessment."

A good example is the European ICS, Astacus leptodactylus Eschscholtz, which was introduced into Western Europe mainly from Eastern Europe after populations of ICS became decimated by crayfish plague (post-1860s). It was brought in for the same reasons that North American NICS were introduced, i.e. to supplement stocks, the main difference being that it was susceptible to crayfish plague (see below). So, in the majority of West European countries, $A$. leptodactylus would not be considered an ICS according to the IUCN ruling (see Table I). The same applies to A. astacus in Britain, and A. pallipes in Scotland (Holdich and Sibley, 2009). However, in some cases a crayfish species that was probably introduced becomes such an important part of a country's culture that it is adopted as an indigenous species (Holdich et al., 2006). Another example concerns the status of $A$. pallipes in England and Wales, where there was very little evidence that it existed there before 1500 AD. Because of this it was in danger of not being included in the IUCN's next Red Data book (Dewhurst, 2009 , pers. comm.). The indigenous status of $A$. pallipes had not generally been questioned by British conservationists and its current high profile has resulted in considerable efforts being made to conserve it (Holdich et al., 2004). An investigation was undertaken and it was found that evidence from the palaeontology record and from genetic studies for the presence of $A$. pallipes in Britain before 1500 is inconclusive, but that there is strong evidence from historical documents and medieval recipes that $A$. pallipes has for centuries been regarded as a valued food resource in Britain. The authors concluded that there is sufficient evidence to indicate that $A$. pallipes was established in the wild in Britain prior to 1500 and that for the purposes of red listing and conservation this species should be regarded as indigenous (Holdich et al., 2009). A similar situation exists with A. pallipes in Ireland and the suggestion is that they were introduced by monastic orders from France as early as the 12th century (Gouin et al., 2003). These views have now been formally recognised by the IUCN (Dewhurst, 2009, pers. comm.). Interestingly, a similar situation exists for $A$. astacus in Sweden, with no evidence in the literature for its existence in the country prior to 1504 (Swahn, 2004).

Populations of ICS and North American NICS occurring in the same waterbody have been reported from many countries, e.g. Austria (Pöckl and Pekny, 2002), Belgium (Cammaerts, 2009, pers. comm.), England (Dunn et al., 2009), Finland (Westman et al., 2002), France (see below), Germany (Hirsch, 2009), Italy (see below), Poland (Śmietana et al., 2004), Switzerland (Hefti and Stucki, 2006), although this does not necessarily mean the NICS are free from crayfish plague (Diéguez-Uribeondo, 2009, pers. comm.). Crayfish plague was found to be present in some populations of $O$. limosus, $P$. leniusculus and $P$. clarkii in Switzerland but not in others (Oidtmann et al., 2004). In Latium (Italy), O. limosus and A. leptodactylus cooccur in Lago del Salto, and P. clarkii and A. leptodactylus in the lakes of Bracciano and Bolsena (Gherardi, 2009, pers. comm.). Out of 3208 riverine and lacustrine sites sampled in Switzerland, 1578 contained ICS, 499 contained NICS, and 62 contained both ICS and NICS (Hefti and Stucki, 2006). 


\section{Table I}

European territories possessing wild populations of ICS and NICS. Grey highlights are new NICS records and/or confirmations since Souty-Grosset et al. (2006). Azerbaijan, Georgia, Kazakhstan, Russia and Turkey are considered part of both Europe and Asia. Armenia and Cyprus are sociopolitical European countries. Turkmenistan (A. leptodactylus and A. pachypus) and Uzbekistan (introduced A. leptodactylus) have not been included.

\section{Tableau I}

Populations de ICS et NICS présentes dans les pays européens. Les nouveaux signalements de NICS et/ou confirmés depuis Souty-Grosset et al. (2006) sont surlignés en gris. Azerbaïdjan, Georgia, Kazakhstan, Russie et Turquie sont considérés à la fois comme Europe et Asie. Arménie et Chypre sont des pays européens. Turkmenistan (A. leptodactylus and $A$. pachypus) et Uzbekistan (A. leptodactylus introduite) ne sont pas inclus.

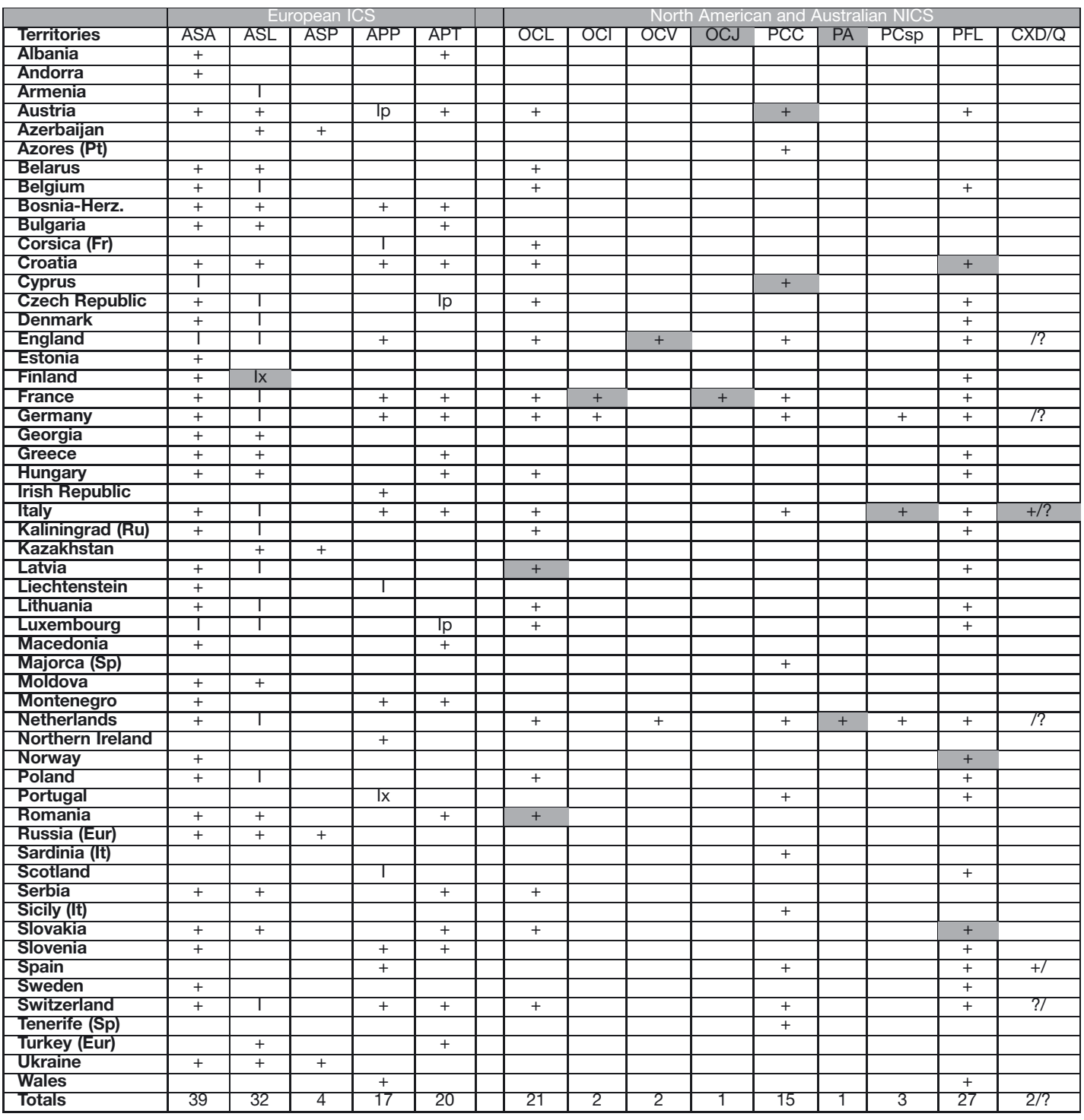

Abbreviations: ASA - Astacus astacus, ASL - Astacus leptodactylus, ASP - Astacus pachypus, APP - Austropotamobius pallipes/italicus, APT - Austropotamobius torrentium, OCL - Orconectes limosus, OCl - Orconectes immunis, OCV - Orconectes virilis, PCC - Procambarus clarkii, Procambarus juvenilis, PA - Procambarus acutus, PCsp - Procambarus sp. (marmorkrebs), PFL - Pacifastacus leniusculus, CXD Cherax destructor, $\mathrm{CXQ}-$ Cherax quadricarinatus. $\mathrm{x}=$ probably no longer present, $\mathrm{I}=$ introduced relatively recently, $\mathrm{Ip}=$ possibly introduced Abréviations: ASA - Astacus astacus, ASL - Astacus leptodactylus, ASP - Astacus pachypus, APP - Austropotamobius pallipes/italicus, APT Austropotamobius torrentium, OCL - Orconectes limosus, OCI - Orconectes immunis, OCV - Orconectes virilis, PCC - Procambarus clarkii, Procambarus juvenilis, PA - Procambarus acutus, PCsp - Procambarus sp. (marmorkrebs), PFL - Pacifastacus leniusculus, CXD - Cherax destructor, $\mathrm{CXQ}-$ Cherax quadricarinatus. $\mathrm{x}=$ probablement absente aujourd'hui, $\mathrm{I}=$ introduite relativement récemment, Ip $=$ probablement introduite. 


\section{Table II}

Number of European ICS and NICS by territory. Records with? marks in Table I are not included. Introduced (I) or probably introduced (IP) ICS shown in Table I are included under ICS except for England, where A. astacus and A. leptodactylus are considered as NICS under the Wildlife \& Countryside Act.

\section{Tableau II}

Nombre d'ICS et NICS européennes par pays. Les signalements marqués? dans le tableau I ne sont pas inclus. Les ICS indiquées comme introduites (I) ou probablement introduites (Ip) dans le tableau I sont considérées comme ICS sauf pour l'Angleterre, où $A$. astacus et $A$. leptodactylus sont considérées comme NICS par le Wildlife \& Countryside Act.

\begin{tabular}{|l|c|c|}
\hline Territory & ICS & NICS \\
\hline Albania & 2 & 0 \\
\hline Andorra & 1 & 0 \\
\hline Armenia & 1 & 0 \\
\hline Austria & 4 & 3 \\
\hline Azerbaijan & 2 & 0 \\
\hline Azores (Pt) & 0 & 1 \\
\hline Belarus & 2 & 1 \\
\hline Belgium & 2 & 2 \\
\hline Bosnia-Herz. & 4 & 0 \\
\hline Bulgaria & 3 & 0 \\
\hline Corsica (Fr) & 1 & 1 \\
\hline Croatia & 4 & 2 \\
\hline Cyprus & 1 & 1 \\
\hline Czech Republic & 3 & 2 \\
\hline Denmark & 2 & 1 \\
\hline England & 1 & 6 \\
\hline Estonia & 1 & 0 \\
\hline Finland & 1 & 1 \\
\hline France & 4 & 5 \\
\hline Germany & 4 & 5 \\
\hline Georgia & 2 & 0 \\
\hline Greece & 3 & 1 \\
\hline Hungary & 3 & 2 \\
\hline Irish Republic & 1 & 0 \\
\hline Italy & 4 & 5 \\
\hline Kaliningrad (Ru) & 2 & 2 \\
\hline Kazakhstan & 2 & 0 \\
\hline & & \\
\hline
\end{tabular}

\begin{tabular}{|l|c|c|}
\hline Territory & ICS & NICS \\
\hline Latvia & 2 & 2 \\
\hline Liechtenstein & 2 & 0 \\
\hline Lithuania & 2 & 2 \\
\hline Luxembourg & 2 & 2 \\
\hline Macedonia & 2 & 0 \\
\hline Majorca (Sp) & 0 & 1 \\
\hline Moldova & 2 & 0 \\
\hline Montenegro & 3 & 0 \\
\hline Netherlands & 2 & 6 \\
\hline Northern Ireland & 1 & 0 \\
\hline Norway & 1 & 1 \\
\hline Poland & 2 & 2 \\
\hline Portugal & 0 & 2 \\
\hline Romania & 3 & 1 \\
\hline Russia (Eur) & 3 & 0 \\
\hline Sardinia (It) & 0 & 1 \\
\hline Scotland & 0 & 2 \\
\hline Serbia & 3 & 1 \\
\hline Sicily (It) & 0 & 1 \\
\hline Slovakia & 3 & 2 \\
\hline Slovenia & 3 & 1 \\
\hline Spain & 1 & 3 \\
\hline Sweden & 1 & 1 \\
\hline Switzerland & 4 & 3 \\
\hline Tenerife (Sp) & 0 & 1 \\
\hline Turkey (Eur) & 2 & 0 \\
\hline Ukraine & 3 & 0 \\
\hline Wales & 1 & 1 \\
\hline & & \\
\hline
\end{tabular}

\section{$>$ ICS}

Little has changed in the occurrence of ICS in Europe since the publication of the crayfish atlas (Souty-Grosset et al., 2006). However, some additional information is added below for each species. Although species are listed as being indigenous in Table I, this indicates they are indigenous to Europe rather than to individual countries, where they may have been introduced from other parts of Europe relatively recently (see above). To indicate these situations "I" or "Ip" have been inserted in the table following Machino and Holdich (2006). The decline of ICS is dealt with in more detail for selected countries, i.e. England, France, Italy, Spain and Portugal, and Sweden in another section. The maps shown in Figures 1, 3, 5 and 7 are taken from the CRAYNET Atlas (Souty-Grosset et al., 2006) and represent data collected up until the end of 2005.

Astacus astacus (Linnaeus, 1758) (noble crayfish) (Figure 2): Currently found in 39 territories across most of northern and central Europe, although its range was greater before the onset 


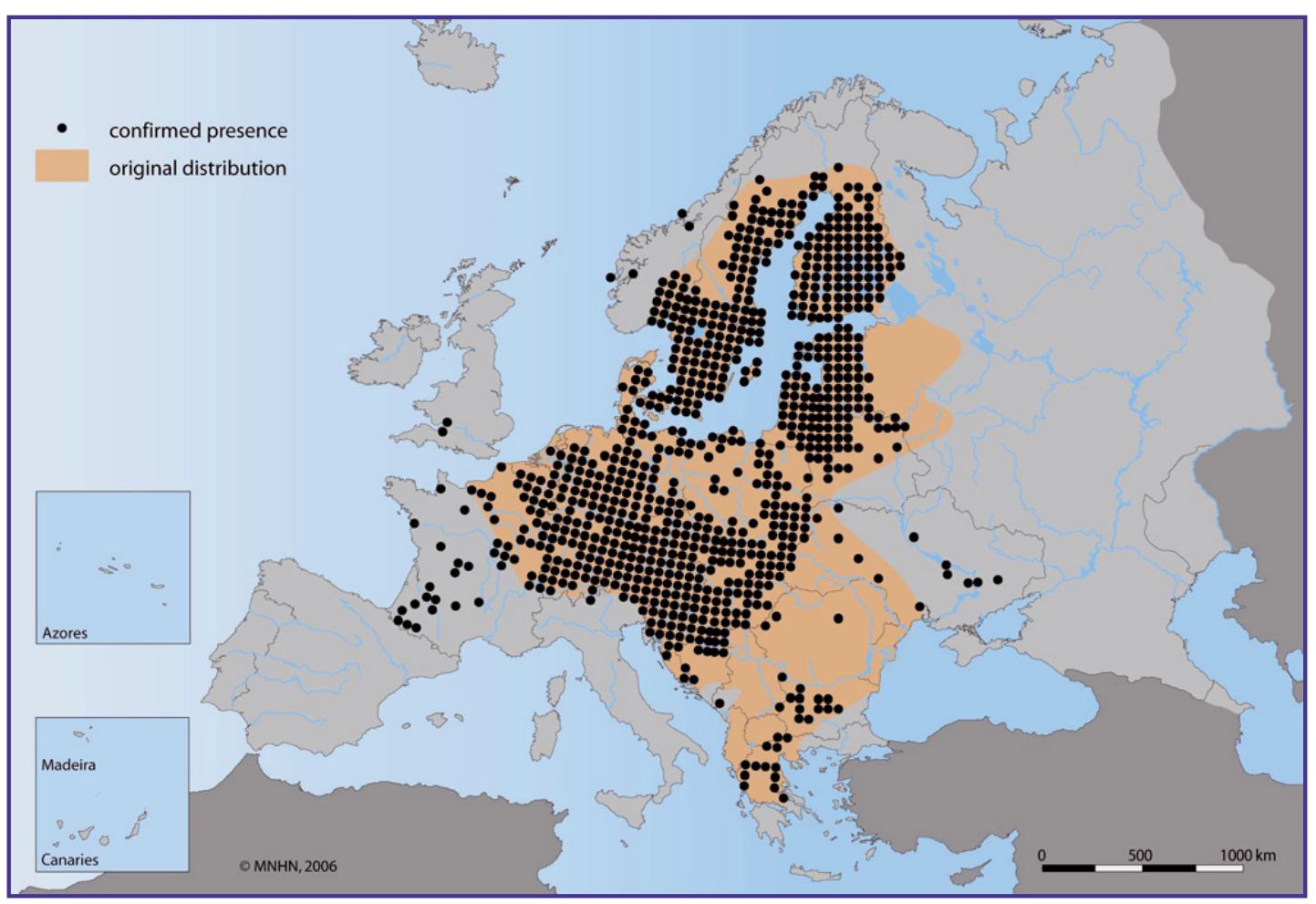

Figure 1

Map showing the distribution of Astacus astacus (CRAYNET atlas).

Figure 1

Carte de distribution d'Astacus astacus (CRAYNET atlas).

of crayfish plague (Figure 1). It is widely harvested and many countries have national and federal regulations governing catching seasons and size restrictions (Skurdal and Taugbøl, 2002). The most abundant populations exist in Nordic and Baltic countries, e.g. it is the dominant crayfish in Latvian waters, having been found in 220 out of 258 crayfish localities (Taugbøl et al., 2004; Arens and Taugbøl, 2005). Astacus astacus was introduced to Cyprus from Denmark in the 1970s and although the original stock has disappeared it apparently occurs in the Lefkara dam (Stephanou, 1987). According to Schmidt (2009, pers. comm.) it has disappeared from Luxembourg. However, it was reintroduced into the R. Our (Troschel, 1999) and a specimen was found at an introduction site at Weiswampach in 2002 (Machino and Holdich, 2006), so it is listed as being still present in Table I.

Astacus leptodactylus Eschscholtz, 1823 (narrow-clawed crayfish) - species complex (Figure 4): Currently found in 32 territories across most of Europe with the exception of Scandinavia and the Baltic Peninsula, although its range was probably greater before the onset of crayfish plague (Figure 3). The systematics of this species complex is in a state of flux with those in Western and Central Europe referring just to $A$. leptodactylus, whilst in Eastern Europe a number of species are recognized within a genus Pontastacus (Starobogatov, 1995; Śmietana et al., 2006). The most abundant populations are found in Eastern Europe and the Near East. Large commercial stocks of A. leptodactylus exist in Belarus (Alekhnovich, 2006), but between 2004-2005 there have been large-scale mortalities in some shallow and deep water lakes with nothing else affected (Alekhnovich, 2009, pers. comm.). However, a lake similarly affected in the 1990s had shown some recovery by 2004-2005. Crayfish plague is thought to be the cause of these mortalities but this has not been proven. This species is prone to the effects of crayfish plague and in recent times there have been reports of introduced populations being affected, e.g. England (Environment Agency, 2007), Switzerland 


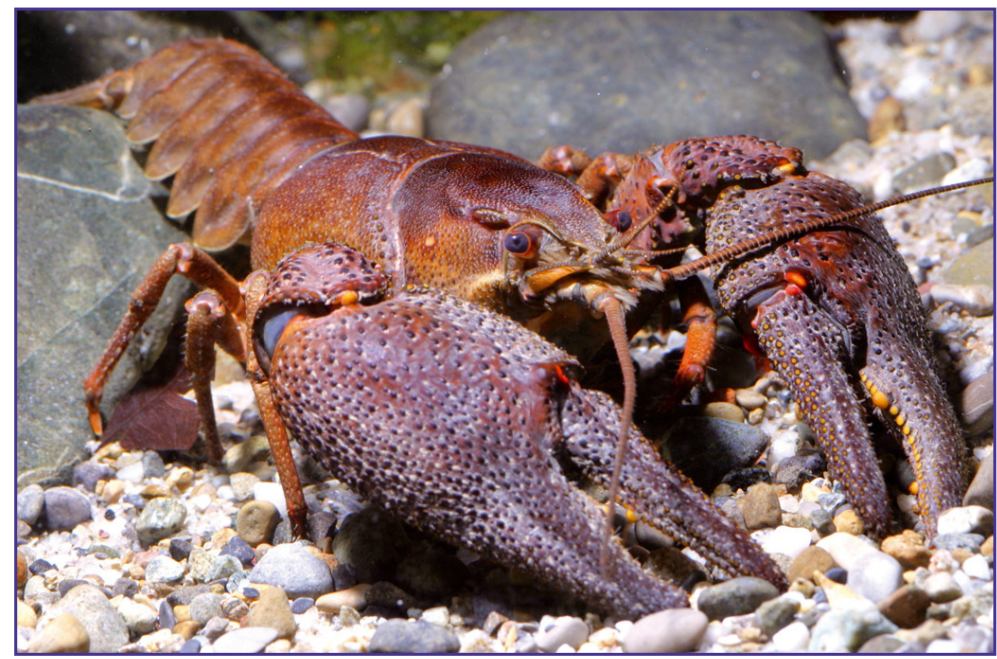

\section{Figure 2}

The noble crayfish, Astacus astacus (C. Lukhaup).

\section{Figure 2}

L'écrevisse à pieds rouges, Astacus astacus (C. Lukhaup).

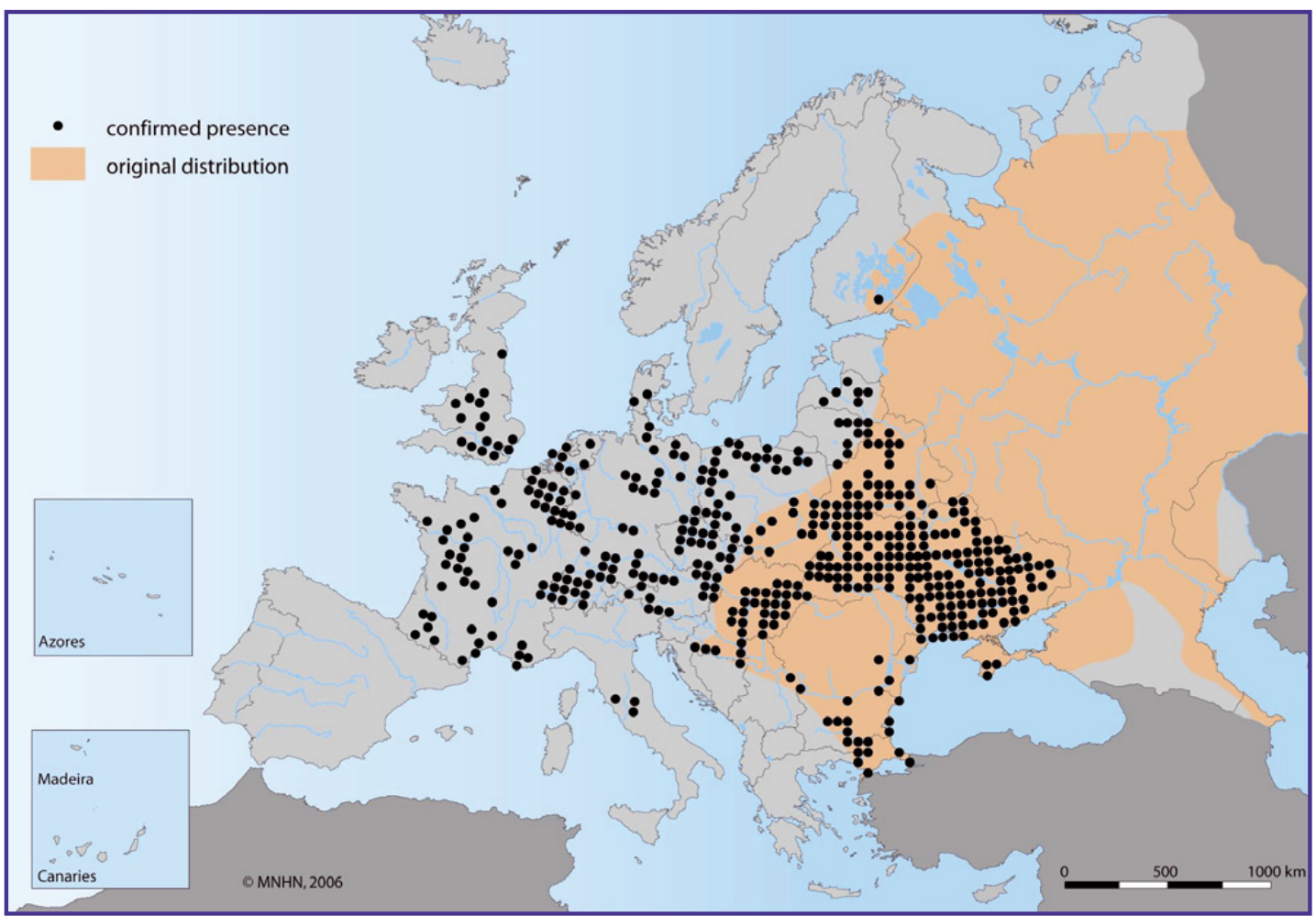

\section{Figure 3}

Map showing the distribution of Astacus leptodactylus (CRAYNET atlas).

\section{Figure 3}

Carte de distribution d'Astacus leptodactylus (CRAYNET atlas). 


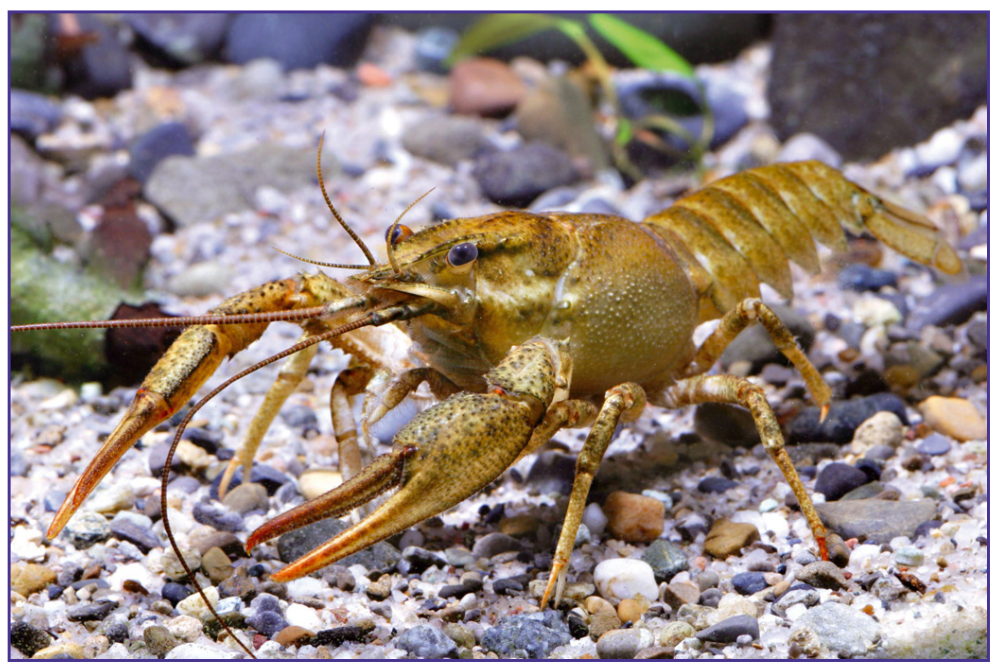

Figure 4

The narrow-clawed crayfish, Astacus leptodactylus (C. Lukhaup).

Figure 4

L'écrevisse à pattes grêles, Astacus leptodactylus (C. Lukhaup).

(Hefti and Stucki, 2006). Simić et al. (2008) report that although A. leptodactylus is spreading in some regions of Serbia in others numbers are being reduced by the presence of $O$. limosus. Although crayfish plague devastated populations in Turkey in the 1980s resulting in very low harvests (down from 5000 tonnes in 1984 to 320 tonnes in 1991) a partial recovery has been recorded in the 2000s, i.e. 2317 tonnes in 2004, and previously plague-infected lakes are productive again (Harlioğlu, 2008). Perdikaris (2009, pers. comm.) has also reported A. leptodactylus from the R. Nestos in Greece, where it was probably deliberately introduced. Tertyshny and Panchishny (2009) have reported large-scale mortalities amongst the industrial stocks of $A$. leptodactylus in the Ukraine, which are partly attributable to disease. Pöckl (2009, pers. comm.) during a recent visit to the Lower Bug River in the Crimean region of the Ukraine found that virtually every house in the village of Rakove was advertising crayfish for sale, and in their cellars they had many containers full with assorted live crayfish according to size, quality, and price.

Astacus pachypus Rathke, 1837 (thick-clawed crayfish): Known from only four countries bordering the Black and Caspian Seas (see map and photo in Holdich et al., 2006). Some astacologists believe that this species should belong to a separate genus Caspiastacus (see Starobogatov, 1995).

Austropotamobius pallipes (Lereboullet, 1858) (white-clawed crayfish) - species complex (Figure 6): Currently found in 17 territories. This species has a narrower range than those of $A$. astacus and $A$. leptodactylus and is more centred in Western, Central and Southern Europe (Figure 5). Machino et al. (2004) have catalogued the many introductions of $A$. pallipes that have been made throughout Europe. If the division of the species into $A$. italicus (Faxon, 1814) and $A$. pallipes is accepted then the distribution map will have to be redrawn (Fratini et al., 2005; Bertocchi et al., 2008a).

Austropotamobius torrentium (Schrank, 1803) (stone crayfish) (Figure 8): Currently known from 20 countries but with a restricted range in Central and South-eastern Europe, where it was most likely more widely spread in the past (Figure 7). It is the most southerly of the European ICS extending as far as Bulgaria and Romania, and has recently been found in Turkey (Harlioğlu, 2007). Perdikaris et al. (2007) have confirmed the presence of $A$. torrentium in the R. Evros in Greece for the first time in 112 years. Trontelj et al. (2005) discuss the distribution of the sub-species of this species. 


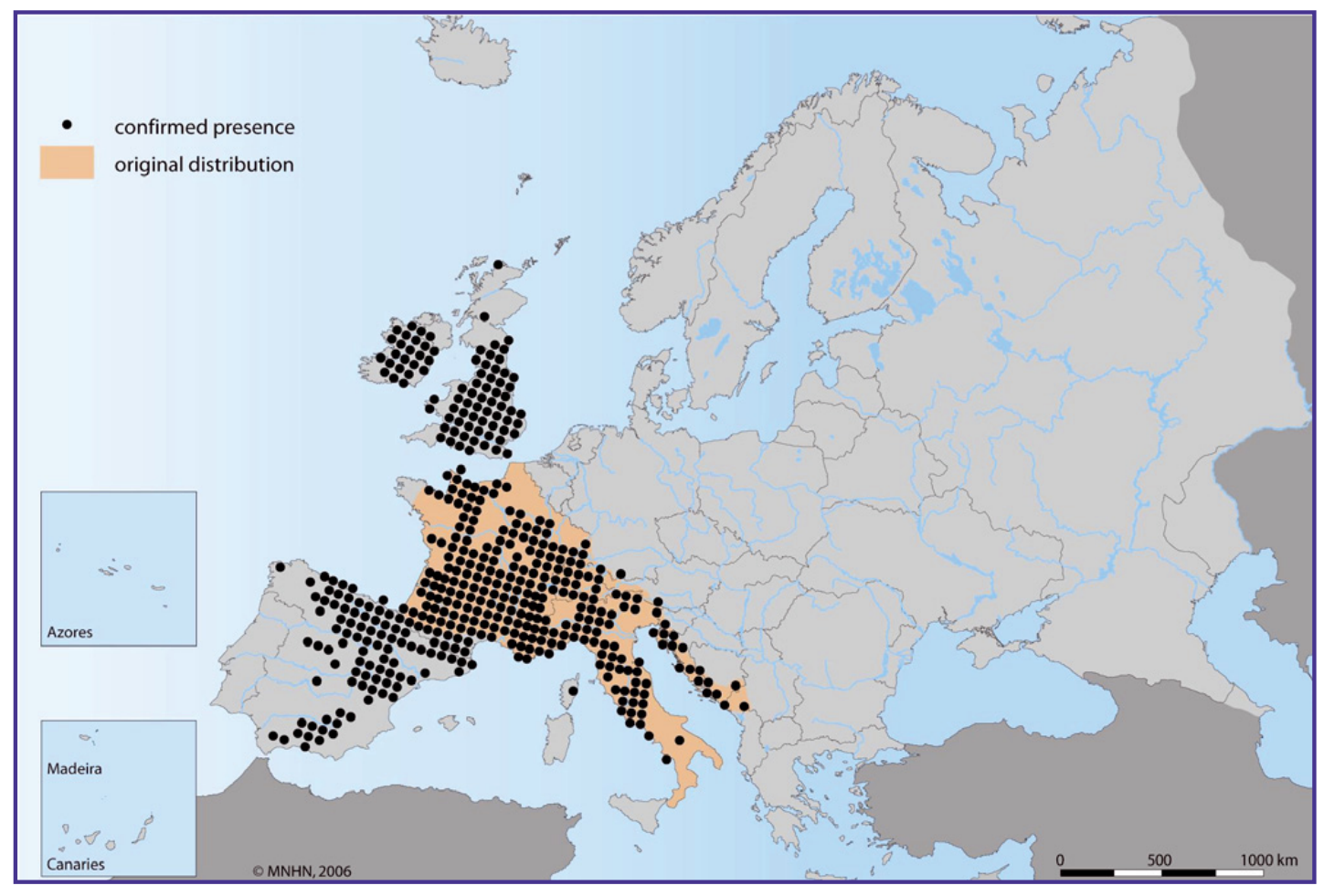

Figure 5

Map showing the distribution of Austropotamobius pallipes (CRAYNET atlas).

Figure 5

Carte de distribution d'Austropotamobius pallipes (CRAYNET atlas).

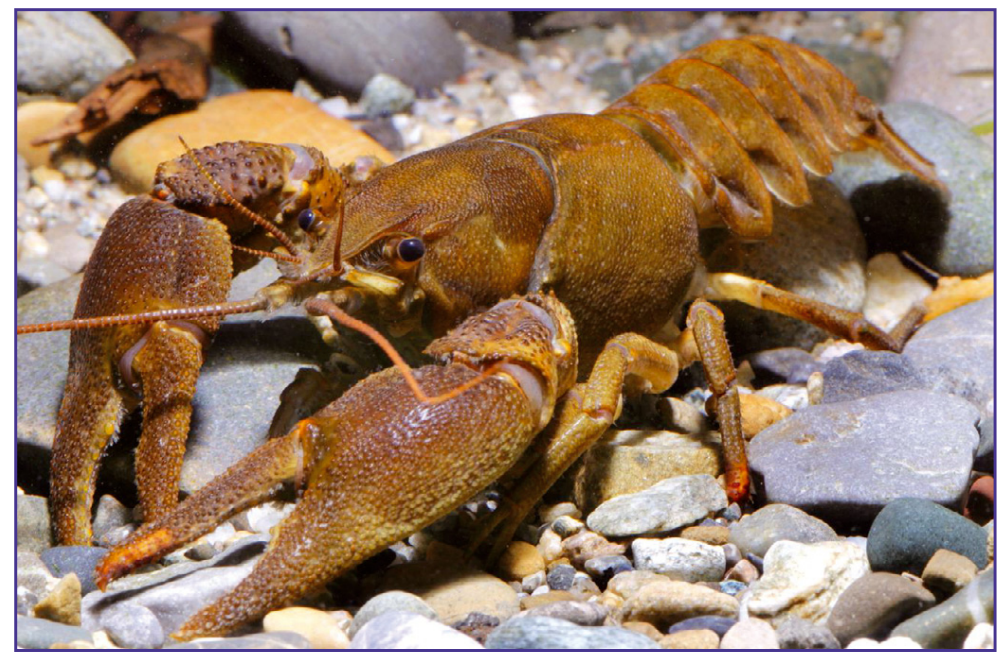

\section{Figure 6}

The white-clawed crayfish, Austropotamobius pallipes (C. Lukhaup).

Figure 6

L'écrevisse à pattes blanches, Austropotamobius pallipes (C. Lukhaup). 


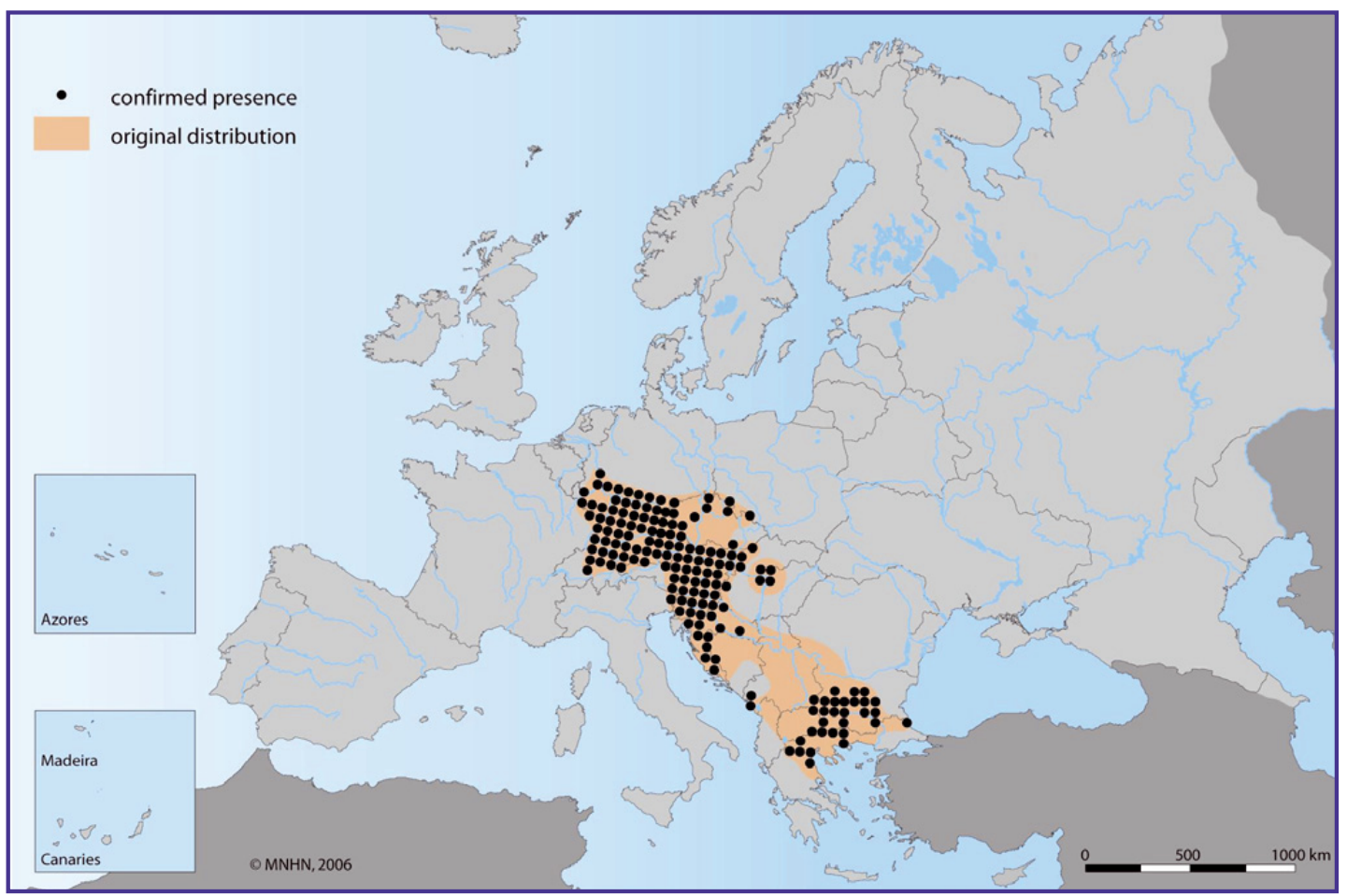

Figure 7

Map showing the distribution of Austropotamobius torrentium (CRAYNET atlas).

Figure 7

Carte de distribution d'Austropotamobius torrentium (CRAYNET atlas).

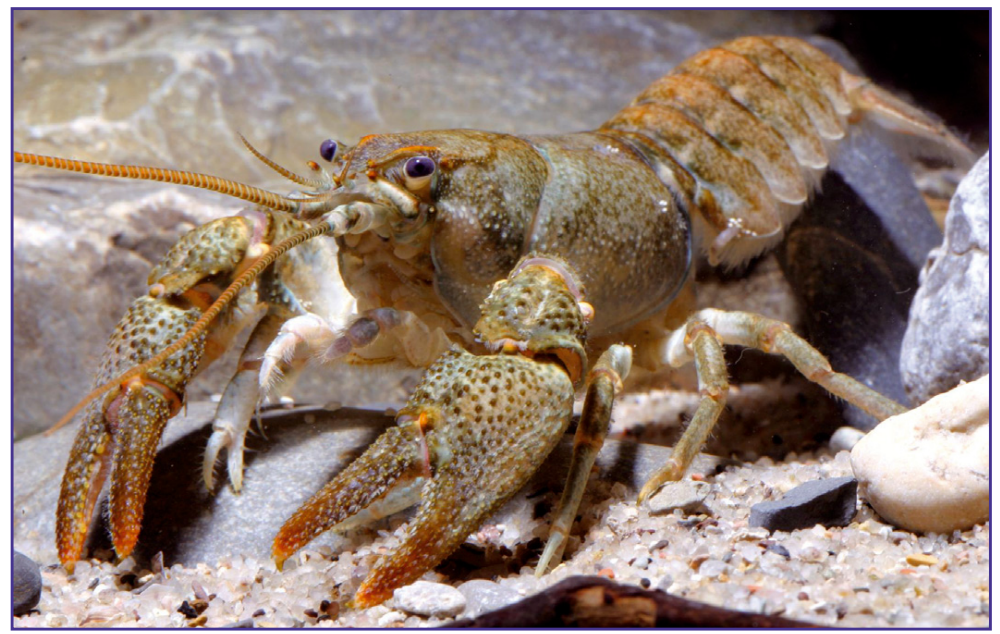

Figure 8

The stone crayfish, Austropotamobius torrentium (C. Lukhaup).

Figure 8

L'écrevisse des torrents, Austropotamobius torrentium (C. Lukhaup). 


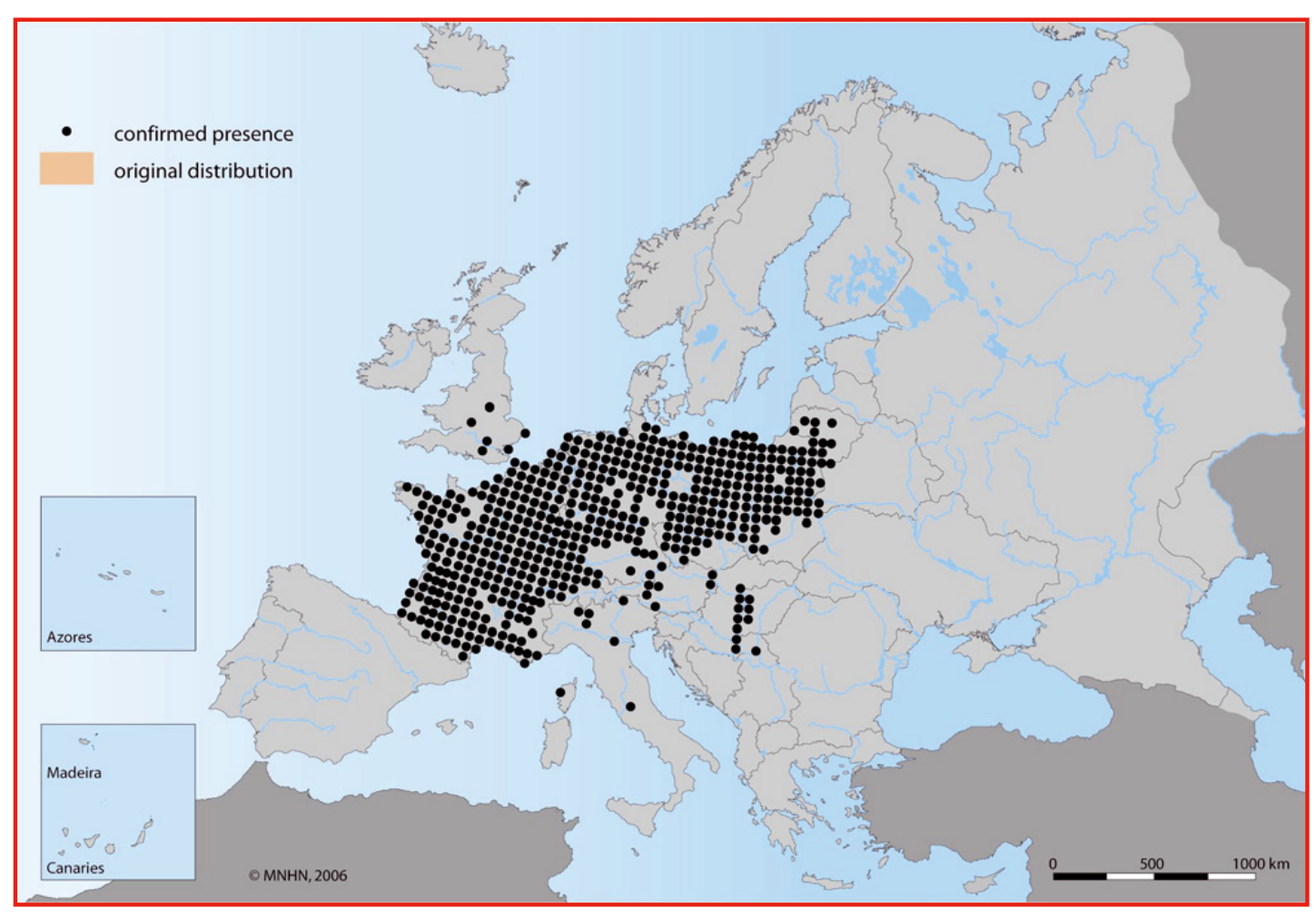

Figure 9

Map showing the distribution of Orconectes limosus (CRAYNET atlas).

Figure 9

Carte de distribution d'Orconectes limosus (CRAYNET atlas).

\section{> OLD NICS AND THEIR CONTINUED SPREAD}

It can be seen from Table I that since the publication of the crayfish atlas (Souty-Grosset et al., 2006) the range of "Old NICS" has expanded in Europe. Most notable is the presence of O. limosus in Latvia (Arens, 2009, pers. comm.) and Romania (Pârvulescu et al., 2009); P. leniusculus in Croatia (Maguire et al., 2008), Norway (Johnsen et al., 2007) and Slovakia (Petrusek and Petruskova, 2007); and P. clarkii in Austria (Strasser and Patzner, 2005). The presence of $P$. clarkii in Cyprus is also confirmed (Stephanou, 1987; Perdikaris, 2009, pers. comm.). The maps shown in Figures 9, 11 and 13 are taken from the CRAYNET Atlas (SoutyGrosset et al. 2006) and represent data collected up until the end of 2005.

Orconectes limosus (Rafinesque, 1817) (spiny-cheek crayfish) (Figure 10): Introduced to Europe in 1890, this species is currently recorded from 21 territories (Figure 9) including the island of Corsica. It is particularly common in Western, Central and Eastern Europe as far east as Belarus, e.g. out of 300 lakes examined in north-east Germany, 214 were found to have populations of $O$. limosus, and in Poland populations of $O$. limosus have increased from 57 in 1959 to 1383 in 2004 (Holdich et al., 2006). A proven vector of crayfish plague, this species is thought to have been responsible for the demise of many populations of ICS in Europe (Holdich et al., 2006). In Belgium, O. limosus is the most successful crayfish species, especially in Flanders where it occurs in virtually every water course and many ponds (Cammaerts, 2009, pers. comm.). According to Puky and Schád (2006) it tends to inhabit the lower stretches of rivers and their tributaries and as a consequence populations of ICS in the upper stretches may be protected from it. Orconectes limosus appears not to be so sensitive to land use changes and human activities as the ICS (Schulz et al., 2002), and it can withstand habitats unfavourable to the ICS such as soft substrates, turbid and muddy 


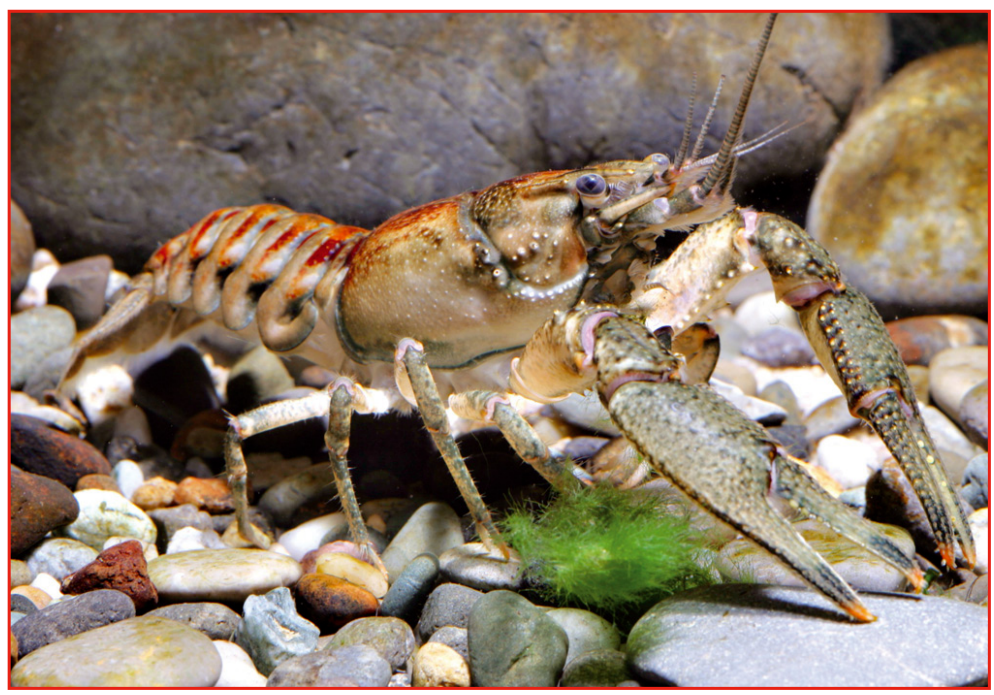

Figure 10

The spiny-cheek crayfish, Orconectes limosus (C. Lukhaup).

Figure 10

L'écrevisse américaine, Orconectes limosus (C. Lukhaup).

waters, polluted canals and organically enriched ponds and lakes (Puky, 2009). Orconectes limosus is common in the western half of the Czech Republic, particularly in the R. Elbe catchment (Petrusek et al., 2006), where it has been identified as a vector of crayfish plague (see below); it was recently found in the Bohemian Forest, which is the most southerly record for the country (Beran and Petrusek, 2006). In Poland, where O. limosus is very common, Krzywosz and Ulikowski (2009) have reported a number of crashes in populations across the country, although the cause is unknown. Burba (2009) gives details of the recent (1998-2004) rapid expansion of $O$. limosus in Lithuania, where it has spread throughout the entire country since the mid-1990s, mainly inhabiting the R. Nemunas and the R. Venta, the latter flowing from Lithuania through Latvia to the Baltic Sea. It has also been recorded from the Baltic Sea coast in Lithuania (Burba, 2008). In Belarus, O. limosus was found in 1997 in rivers bordering Poland and Lithuania, and now mainly occurs in the R. Neman. In 2009, O. limosus was found in large quantities in the Lesnya Levaya River, which belongs to the R. Narev basin (Baitchorov and Giginiak, 2009). The invasion in Belarus appears to be upstream. It is now in rivers close to the R. Yaselda, which is in the Black Sea basin.

Stloukal and Harváneková (2005) reported no NICS from Slovakia, but Jansky and Kautman (2007) reported the presence of O. limosus in the R. Ipel' and Váh close to the R. Danube in 2007 and this was confirmed by Puky (2009). Orconectes limosus was introduced to Hungary from Germany in the 1950s for farming but the venture was unsuccessul, and it was not found in the country until it appeared in the R. Danube in 1985 (Puky and Schád, 2006). The main catch in the river in the 1990s consisted of $A$. astacus but this is now dominated by O. limosus. It has now colonized the complete Hungarian stretch of the R. Danube south to Budapest since 1985, and has also been spreading fast along the R. Tisza and its tributaries (Sallai and Puky, 2008). Its downstream colonization rate over 20 years has been estimated to be $13 \mathrm{~km} \cdot \mathrm{yr}^{-1}$ (Puky and Schád, 2006). If one takes into account its recent occurrence in Croatia then this increases to $16 \mathrm{~km} \cdot \mathrm{yr}^{-1}$ (Puky and Schád, 2006). Orconectes limosus has entered Croatia through the R. Danube from Hungary. It has entered the R. Drava in Croatia and is spreading upstream some $1.5 \mathrm{~km} \cdot \mathrm{yr}^{-1}$ affecting populations of $A$. leptodactylus (Maguire and Klobučar, 2003; Faller et al., 2009). Orconectes limosus has recently spread down the Danube to Serbia (Karaman and Machino, 2004; Pavolić et al., 2006; Simić et al., 2008) and Romania (Pârvulescu et al., 2009). It seems likely that rapid spread of this species 


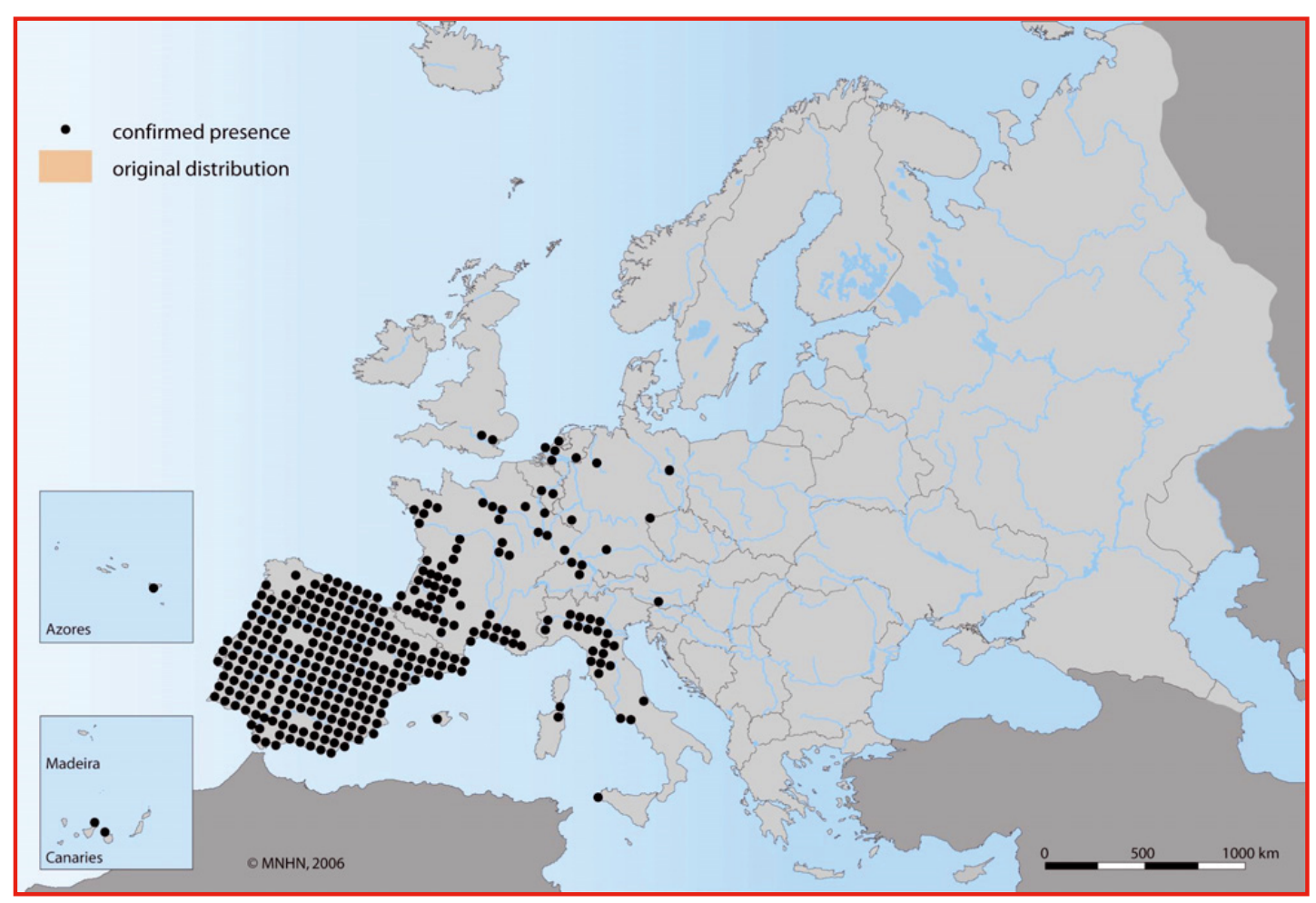

\section{Figure 11}

Map showing the distribution of Procambarus clarkii (CRAYNET atlas).

Figure 11

Carte de distribution de Procambarus clarkii (CRAYNET atlas).

in the R. Danube may well be partly due to deliberate introductions. Kozubíková et al. (2009) found that a high percentage, but not all individuals, of $O$. limosus carried crayfish plague in the Czech Republic, and were responsible for recent mortalities of indigenous species. Petrusek et al. (2006) found that O. limosus was mainly restricted to the R. Elbe catchment in the eastern half of the Czech Republic, but was likely to spread naturally upstream from the R. Danube into the R. Morava catchment, or by human translocations from the R. Oder and R. Vistula in Poland (Kozák et al., 2004).

ICS have been found co-existing with O. limosus in large rivers in Austria (Pöckl and Pekny, 2002), in a quarry lake in Belgium (Cammaerts, 2009, pers. comm.), in a lake in Italy (Gherardi, 2009, pers. comm.), and in Lake Constance (Germany), where O. limosus co-exists with A. leptodactylus (Hirsch, 2009), as apparently it does in many other lakes in southern Germany (Hirsch, 2009, pers. comm.). Hirsch and Fischer (2008) have shown that in Lake Constance, O. limosus may have a negative impact on juvenile of burbot (Lota lota). Schulz et al. (2006) have recorded the occurrence of $A$. astacus and $O$. limosus in a number of lakes in Poland, and suggest that $O$. limosus is gradually displacing $A$. astacus by direct competition rather than disease. Keller and Stucki (2008) have recently reviewed the distribution of $O$. limosus in some European countries.

Procambarus clarkii (Girard, 1852) (red swamp crayfish) (Figure 12): Currently recorded from 15 territories, including a number of islands, i.e. São Miguel (Azores), Cyprus, Majorca, Sardinia, Sicily and Tenerife (Figure 11). The most recent expansion to its range is to Austria (Strasser and Patzner, 2005; Petutschnig, 2008). It had apparently been introduced to Cyprus some time ago, where it flourished in the Athalassa dam, and was also introduced into two other dams, but the reference has only come to light recently (Stephanou, 1987). Perdikaris (2009, pers. comm.) has confirmed its presence on the island through 


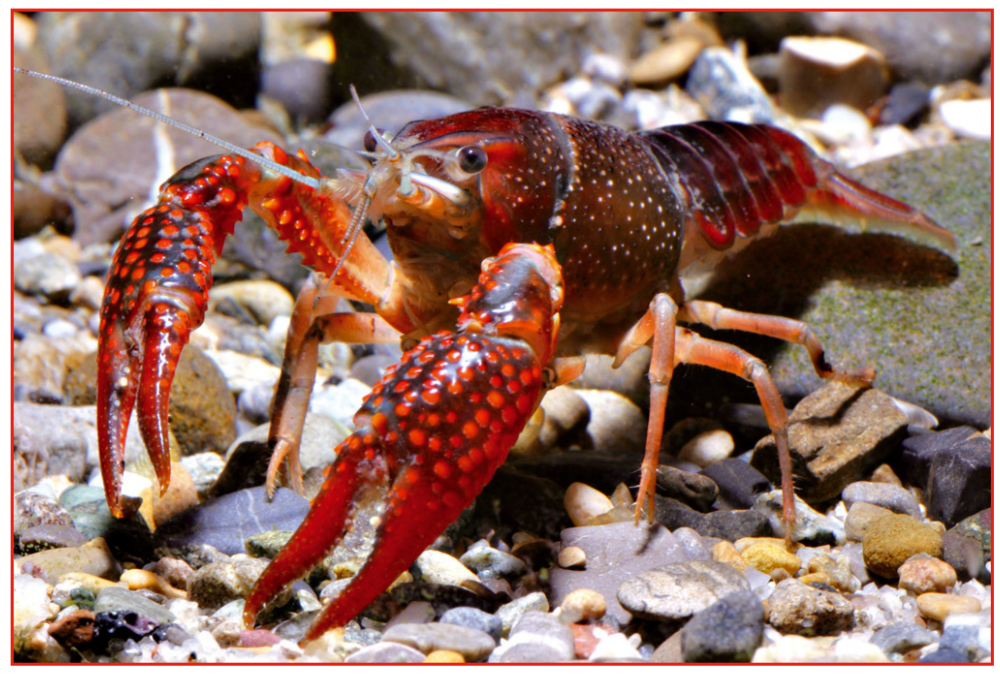

Figure 12

The red swamp crayfish, Procambarus clarkii (C. Lukhaup).

Figure 12

L'écrevisse de Louisiane, Procambarus clarkii (C. Lukhaup).

a third party. Populations are most prevalent in Italy (see below), Portugal, Spain (see below) and The Netherlands. In the Azores it is present in three lakes on São Miguel but does not occur on any of the other islands (Costas, 2009, pers. comm.). Although outside the geographical range of this paper it is worth noting that a reproducing population of $P$. clarkii has recently been found in Israel (Wizen et al., 2008). In Spain, Alcorlo et al. (2006) have shown how $P$. clarkii can be used as an indicator of the bioavailabilty of heavy metals. In addition to being a vector of crayfish plague, due its short life-history, rapid growth, burrowing activities and high population density it can impact adversely on the aquatic environment (Rodriguez et al., 2003, 2005; Gherardi, 2006; Gherardi and Acquistapace, 2007). Further details of $P$. clarkii in Spain and Italy are given below.

Pacifastacus leniusculus (Dana, 1852) (signal crayfish) (Figure 13): Currently known from 27 territories. This is the most widespread of the NICS (Figure 14). Most populations have been derived from implants made into Sweden in 1959 and subsequently. These were mainly derived from Lake Tahoe in California. However, as well as obtaining P. leniusculus from Sweden, Finland imported stock directly from North America in 1967-1968. The species was illegally introduced into Austria from California and into France from Oregon. It is most widespread in Sweden (some 4000 populations in 2008; Edsman, 2009, pers. comm.), Finland and England (see below). In 2006 plague-carrying $P$. leniusculus were found for the first time in Norway, although the population is now thought to have been eradicated (Johnsen et al., 2007). In 2008 they were found in the Halden watercourse, which had previously been struck with crayfish plague (Johnsen and Vrålstad, 2009). In 2003 it was found in Slovenia having moved down the R. Mura in Austria and subsequently into the R. Ščavnica (Bertok et al., 2003; Govedič, 2003); and 2005 in the R. Morava in Slovakia, having either been introduced by Austrian fishermen or invaded from waterbodies in Austria (Petrusek and Petruskova, 2007). In north-west Italy, P. leniusculus was introduced into Brugneto Lake in 2002 and poses a threat to the R. Po watershed (Capurro et al., 2007); records for north-east Italy have been noted by Machino (1997) and Füreder and Machino (1999) in the Adige River basin. Pacifastacus leniusculus is having an impact on the macrophyte beds and aquatic snails in Lake Geneva, but an unexpected consequence of this is a reduction in the prevalence of swimmer's itch, caused by a snail-borne trematode (Dubois et al., 2006). It is present in the R. Gyöngyös in Hungary, and specimens have proved positive for crayfish plague (Kiszely, 2006). In the northern part of Croatia, $P$. leniusculus has been recorded for the first time coming down the R. Mura from 


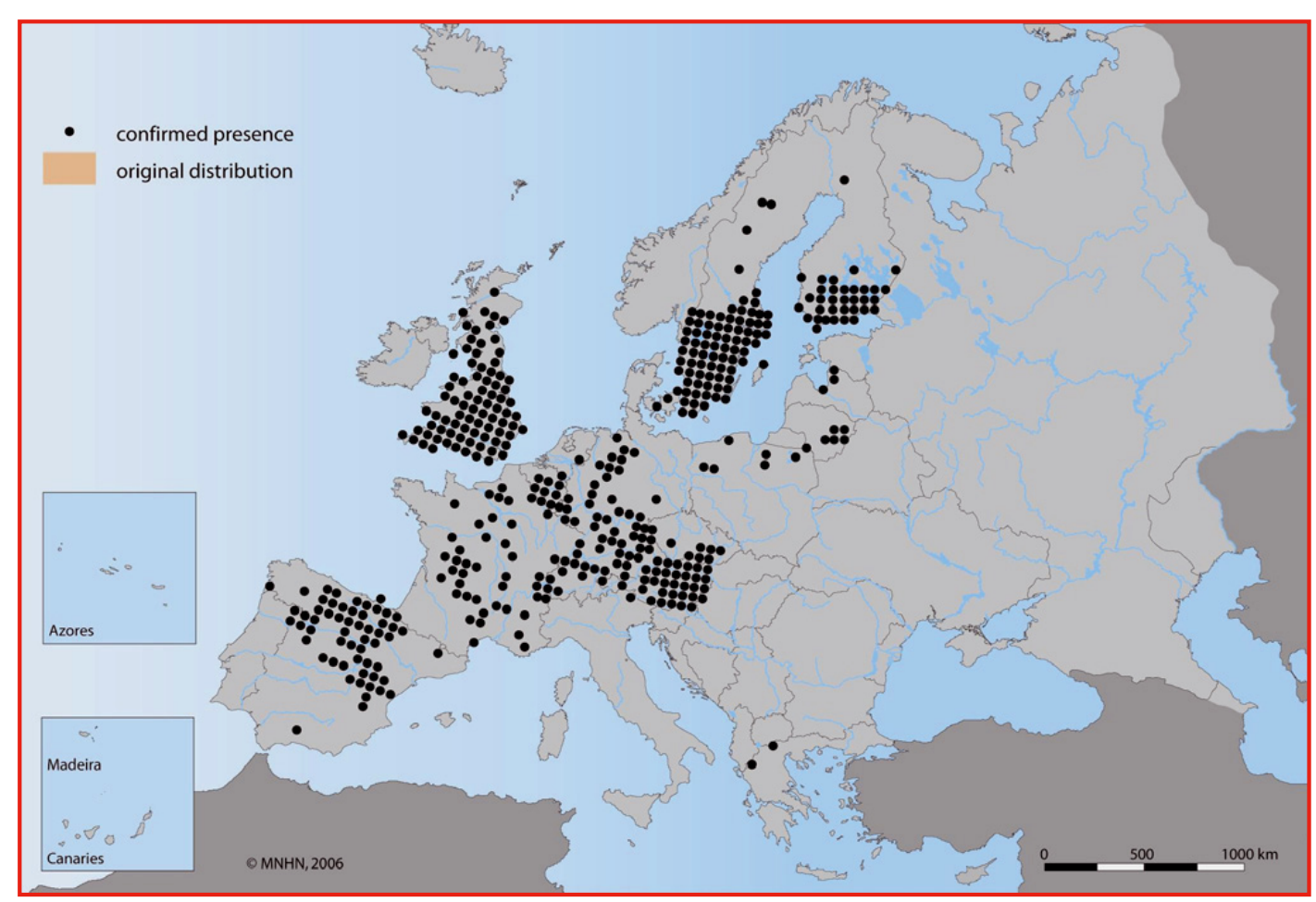

Figure 13

Map showing the distribution of Pacifastacus leniusculus (CRAYNET atlas).

Figure 13

Carte de distribution de Pacifastacus leniusculus (CRAYNET atlas).

Slovenia and will probably enter the R. Drava (Maguire et al., 2008). From the first record in Slovenia in 2003 it has been calculated that $P$. leniusculus has moved at $13.8 \mathrm{~km} \cdot \mathrm{yr}^{-1}$ down the R. Mura by 2009 (Hudina and Lucić, 2009). The rapid spread of $P$. leniusculus can also be illustrated by the situation in Scotland, where it was first discovered in 1995 (Maitland, 1996) and in just over 10 years it has spread to eight locations, including $58 \mathrm{~km}$ of river (Gladman et al., 2009). Its impact on A. pallipes in South-West England is dealt with below. In addition to being a vector of crayfish plague, due to its rapid growth, burrowing activities and high population density it can impact adversely on the aquatic environment (Guan, 1994; Guan and Wiles, 1996, 1997). It has been estimated that in some stretches the banks of the River Lark in England are being eroded by $1 \mathrm{~m} \cdot \mathrm{yr}^{-1}$ due the burrowing activity of $P$. leniusculus (Stancliffe-Vaughan, 2009). The impact that $P$. leniusculus is having on the resident biota in parts of England is such that in some cases it is thought to be preventing waterbodies from attaining good ecological status as prescribed under the Water Framework Directive. Further details of $P$. leniusculus are given below.

\section{$>$ NEW NICS}

(For photos and maps of the species below see Holdich et al., 2006; Pöckl et al., 2006; except for O. juvenilis - see Chucholl and Daudey, 2008.)

It can be seen from Table I that since the publication of the CRAYNET atlas (Souty-Grosset et al., 2006) a number of "New NICS" have appeared in Europe, and others have expanded their range.

Orconectes immunis (Hagen, 1870) (calico crayfish): This species was introduced through the aquarium trade in Germany and is kept as a pet in aquaria and garden ponds. A single individual was originally found in a small canal in the upper Rhine valley in southern Germany 


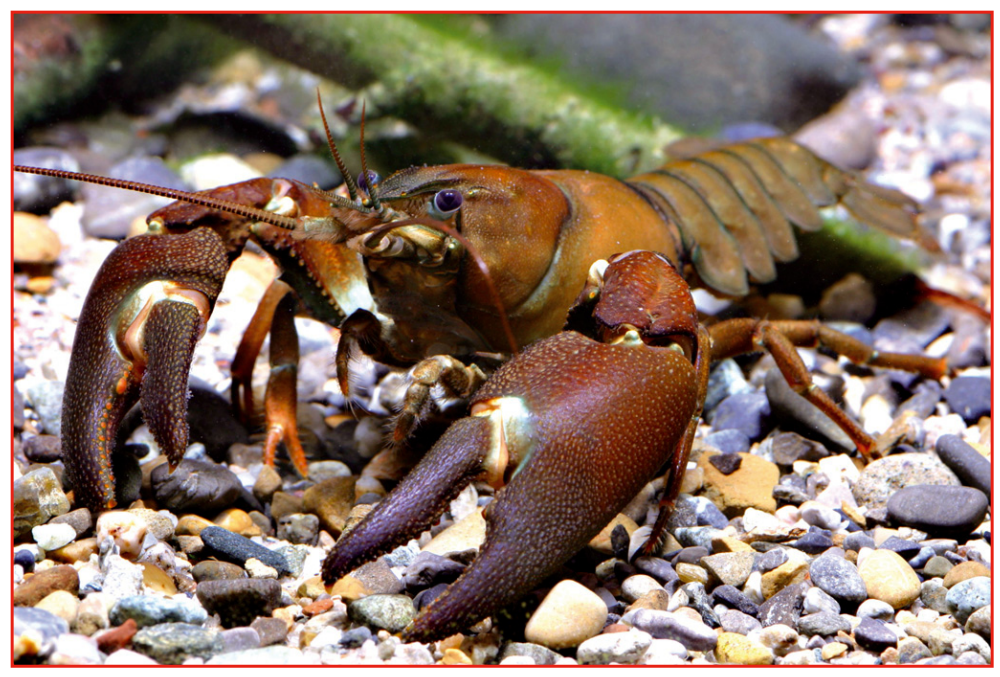

\section{Figure 14}

The signal crayfish, Pacifastacus leniusculus (C. Lukhaup).

Figure 14

L'écrevisse signal, Pacifastacus leniusculus (C. Lukhaup).

in 1997 (Dehus et al., 1999), although according to Gelmar et al. (2006) the first reliable record is from 1993. A breeding population was subsequently discovered and this has spread down the R. Rhine to Karlsruhe, a distance of $45 \mathrm{~km}$ from the original site, and possibly further to Speyer some $35 \mathrm{~km}$ downstream (Dehus et al., 1999). Gelmar et al. (2006) have since recorded it from 28 localities in the Upper Rhine region, in Baden-Württemburg, as well as in France and Rheinland-Palatinate, and Martens (2009, pers. comm.) states that this has increased to 35 localities in 2009 and that the species is entering the Black Forest region. According to Chucholl et al. (2008) and Chucholl (2009) it is displacing another NICS, O. limosus, which has been present in the upper Rhine system for at least five decades. Orconectes immunis digs deep burrows, which allow it to occupy shallow and temporary water bodies (Chucholl, 2009).

Orconectes virilis (Hagen, 1870) (virile crayfish): First recorded in The Netherlands in 2004 (Soes and van Eekelen, 2006), but it is thought to have been present before that as it was already widespread. It is now known from numerous sites and had colonized several hundred kilometres of waterway by 2006 (Koese and Blokland, 2008; Soes, 2008, pers. comm.). In some sites it has displaced $O$. limosus. It is thought to be having a negative impact on the freshwater environment in The Netherlands (Soes, 2008, pers. comm.). Orconectes virilis was originally identified as O. limosus from a pond near the River Lee in north London in 2004 (see Holdich and Black, 2007); however, Ahern et al. (2008) re-identified it as O. virilis, and recorded it in watercourses adjacent to the pond within a $7 \mathrm{~km}$ radius, a dispersal rate of more than $2 \mathrm{~km} \cdot \mathrm{yr}^{-1}$. It is thought that the original population was derived from the dumping of the contents of an aquarium. Apparently, although densities are fairly low, this species is still spreading downstream in the Lee Navigation and connecting streams and ditches (Ellis, 2009, pers. comm.). Filipová et al. (2009) studied the molecular genetics of specimens from England (R. Lee) and The Netherlands, finding them to be of the same lineage, but different from American specimens analysed.

Orconectes juvenilis (Hagen, 1870): In the CRAYNET atlas this species was referred to as Orconectes rusticus (Girard, 1852), but it has since been re-identified as the closely-related species O. juvenilis (Hagen) by Chucholl and Daudey (2008). It escaped from a breeding population in ponds at a restaurant advertising crayfish as a delicacy into the R. Dessoubre in eastern France where it was discovered in 2005, and has since become established; in 2006 it was found to have colonized at least a $700 \mathrm{~m}$ stretch of the river. 
Procambarus sp. (marbled crayfish/marmorkrebs): This unique species is currently only known from a small number of sites in three European countries. It was first recorded from The Netherlands in 2004 (Soes and van Eekelen, 2006). In Germany, Procambarus sp. is known from at least two sites (Marten et al., 2004; Schulz et al., 2009), including a gravel pit near Karlsruhe and a waste treatment pond near Braunschweig (Schulz et al., 2009). An eggbearing specimen and juveniles have recently been recorded from a natural lake near Freiburg in the Black Forest (Schulz, 2009, pers. comm.). Recently, a single specimen of Procambarus sp. was found amongst a population of $P$. clarkii in Tuscany, Italy (Marzano et al., 2009). It is widely available through the aquarium trade and on the internet and is a popular pet in many countries in Western and Eastern Europe. It has recently been shown to be capable of harbouring crayfish plague (Environment News Service, 2008). In addition, due to its parthenogenetic properties it is being highlighted as a useful laboratory animal (Vogt, 2008). The only country where it has become widely established is Madagascar (Jones et al., 2009).

Procambarus acutus (Girard, 1852): So far has only been recorded from The Netherlands, where it has been present since 2005 (Soes and van Eekelen, 2006), a fact not known when the atlas was compiled. Procambarus acutus is closely related to $P$. zonangulus Hobbs \& Hobbs, 1990, and it was known for sure which of the two species was present; however, Soes (2009, pers. comm.) has recently confirmed that it is $P$. acutus. Procambarus acutus was thought to have been originally introduced into Spain along with $P$. clarkii in the 1970s (Henttonen and Huner, 1999), but did not become established. The taxonomy of $P$. acutus and $P$. zonangulus is discussed by Huner (2002). The only record for $P$. zonangulus outside of North America or possibly Europe is from the R. Nile in Egypt, where it co-occurs with P. clarkii (Ibrahim et al., 1997).

Cherax destructor Clark, 1936 (yabby): This Australian species is farmed in Italy (D'Agaro et al., 1999) and has recently been recorded from the wild in central Italy (Scalici et al., 2009). It was introduced into Northern Spain from a crayfish farm in California in 1983, and further introductions were carried out in 1984 and 1985 (Bolea, 1996). Some Spanish populations in ponds were eradicated by using crayfish plague in 2005 (Holdich et al., 2006), but other populations still exist (Camargo and Gonzalo, 2009). Cherax destructor is available from fish markets in some European countries, e.g. Germany and Switzerland. It has been found in the wild in Switzerland, where it can be legally imported for human consumption, but there have been no reports of it becoming established (Stucki and Jean-Richard, 2000; Hefti and Stucki, 2006). It is also kept as an aquarium pet in Switzerland and could be released into the wild by owners or escape from ponds (Wittenberg, 2005).

Cherax quadricarinatus (von Martens, 1868) (redclaw): There are no confirmed wild populations of this Australian species in Europe, although it is widely available through the aquarium trade and live food trade. It is the only species from outside of Europe to be legally allowed into Britain, but only for aquarium purposes (Holdich et al., 2004). There has been one report of a breeding pond population in Germany (Lukhaup, 2007, pers. comm.), but confirmation of this has not been forthcoming, although one us (DMH) has seen a photograph clearly indicating that it is this species. It was found by divers in a gravel pit near Cologne (Germany) in 2005, but an intense survey the following year did not reveal any specimens (Schulz et al., 2009). Cherax quadricarinatus is apparently being abandoned by owners and they have been found in the wild in the Netherlands (Soes, 2008) and England (Holdich and Sibley, 2009), but there have been no reports of populations developing. Cherax quadricarinatus is farmed in Italy (D'Agaro et al., 1999). Perdikaris (2009, pers. comm.) has found specimens of C. quaricarinatus imported from Italy in pet shops and restaurant aquaria in Greece. Control of illegal imports of exotic species is apparently practically absent in Greece.

\section{> POTENTIAL INTRODUCTIONS}

In addition to the above, many species of crayfish from the Americas and Australia are advertised for sale on the internet and in some aquarist catalogues in Europe, e.g. Procambarus alleni, P. clarkii, P. sp., P. spiculifer, P. toltecae, Orconectes durelli, O. luteus, Cambarus 
coosae, C. manningi, C. rusticiformis, C. speciosus, Cambarellus chapalanus, C. montezumae, C. patzcuarensis, C. puer, C. shufeldtii, Cherax destructor, C. holthuisi, C. Iorentzi, C. quadricarinatus, Cherax spp. of various colour varieties, and Samastacus spinifrons. The potential exists for any of these species to be released into the inland waters of Europe. Stloukal and Vitázková (2009) mention the fact that in Slovakia P. clarkii and P. sp. occur in garden ponds and present a high invasion risk.

\section{CASE STUDIES OF THE DECLINE OF ICS IN EUROPE}

The IUCN has recently been reviewing data concerning the population decline of $A$. astacus, $A$. pallipes and $A$. torrentium in Europe (see below). We show below that the decline for these species is serious and use the situation in England, Italy, France, the Iberian Peninsula, Sweden and Finland in particular to illustrate this. In addition, information is given about the situation in some other countries.

\section{$>$ ENGLAND}

As highlighted by Sibley et al. (2009) and Holdich and Sibley (2009), the situation in England concerning the decline of $A$. pallipes is serious. A 95\% reduction in $A$. pallipes populations at the $2 \mathrm{~km}$ square level in the county of Hampshire has occurred since the 1970s. A likely loss of $>95 \%$ has been recorded by the Thames Environment Agency since the 1970s; four NICS occur in the sub-catchments of the Thames Basin and whereas A. pallipes once occurred in all the major tributaries it has only been recorded in eight of the 55 sub-catchments since 2004 (Ellis, 2009). In the counties of East and West Sussex a 100\% loss of $A$. pallipes is likely since the 1970s, while only a few small populations exist in Kent. Pugh (2008) and Pugh et al. (2008) have documented the severe decline of $A$. pallipes in Essex and Suffolk, thought mainly to be due to NICS and crayfish plague. An estimated $77 \%$ decline in populations in Eastern England has occurred over the last 30-40 years. The prediction that $A$. pallipes will disappear from all $10 \mathrm{~km}$ squares nationally by the 2030s (Sibley, 2004) looks like becoming a reality, although only for South-West England is the data available to make a more informative estimate, i.e. 2038, if $P$. leniusculus continues to spread.

The situation concerning $A$. pallipes is considered critical in South-West England (Sibley et al., 2009). Figure 15a shows its approximate distribution in 1975 before the introduction of NICS. Its range is wide, although somewhat restricted by unsuitable water quality and geology. Figure 15b shows the situation in 2009 following more than three decades of deliberate introductions, escapes and continued colonization by NICS. Three NICS are now present (Figure 15c), i.e. A. astacus, $A$. leptodactylus and $P$. leniusculus. Of these only $P$. leniusculus has become widespread and this has been at the expense of $A$. pallipes, mainly through outbreaks of crayfish plague since the 1980s. It has also colonized waters not suitable for $A$. pallipes. Since 1990-1996 there has been a 28\% decline in $A$. pallipes distribution by $10 \mathrm{~km}$ squares in South-West England and an increase of $71 \%$ in NICS. However, if one looks at this from a sub-catchment point of view the decline is more dramatic. Pre-1975, 87 sub-catchments in South-West England were occupied by $A$. pallipes, but at the end of 1999, this had declined to 48 , and by the end of 2008 to 26 . This represents a decline by sub-catchment of $45.8 \%$ from the end of 1999 to the end of 2008, and a decline of $70.1 \%$ from 1975 to the end of 2008.

Faced with this decline the need for a strategic approach to crayfish conservation through translocations to isolated "ark" sites has become more urgent if the future of A. pallipes is to be secured (Peay, 2009). "An ark site is a new refuge site where populations of ICS can be established, safe from NICS and crayfish plague. It is an isolated, self-contained site with running water, still water, or both, which can support a healthy, self-sustaining population with little need for ongoing management" (www.buglife.org.uk). In England the South West Crayfish Project was conceived in response to the chronic decline in A. pallipes outlined above 
(a)

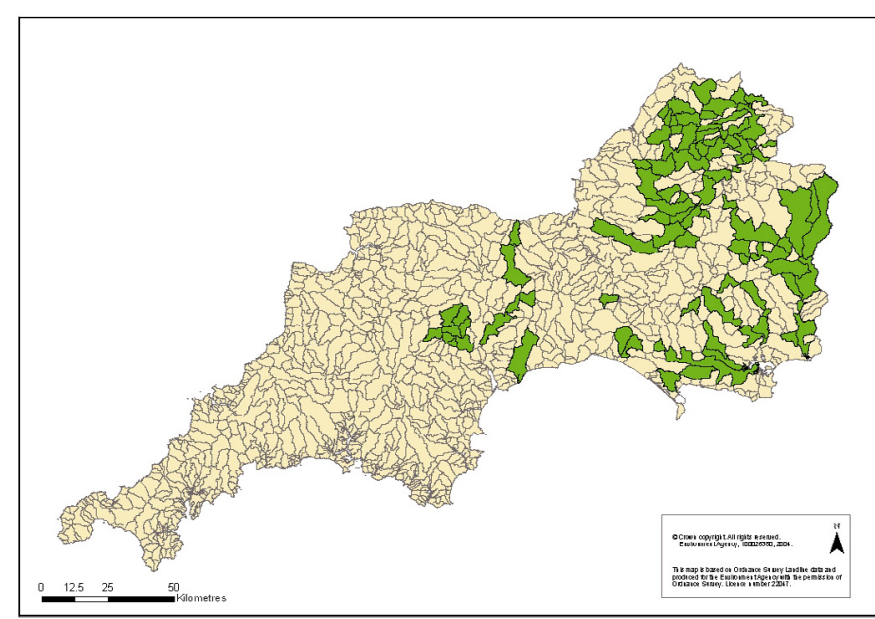

(b)

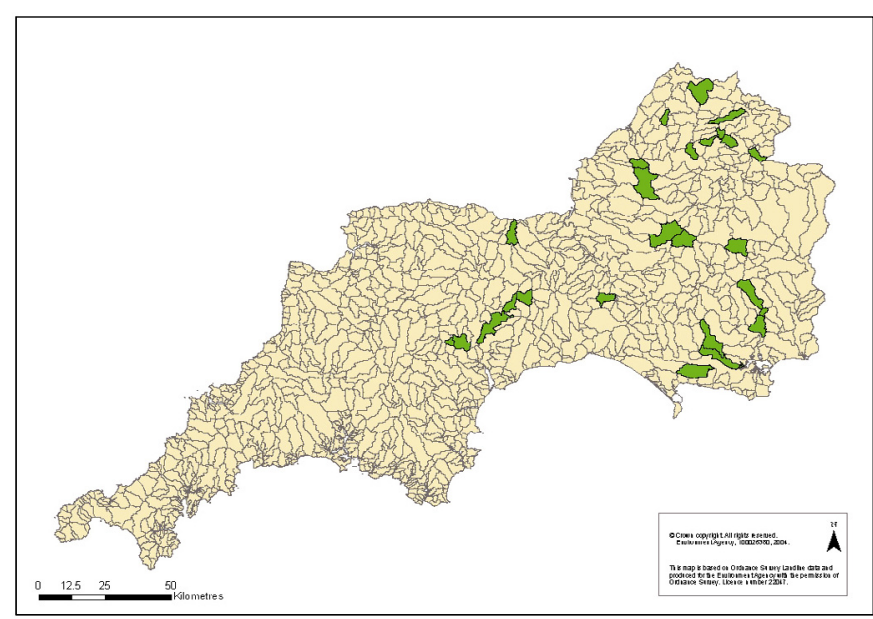

(c)

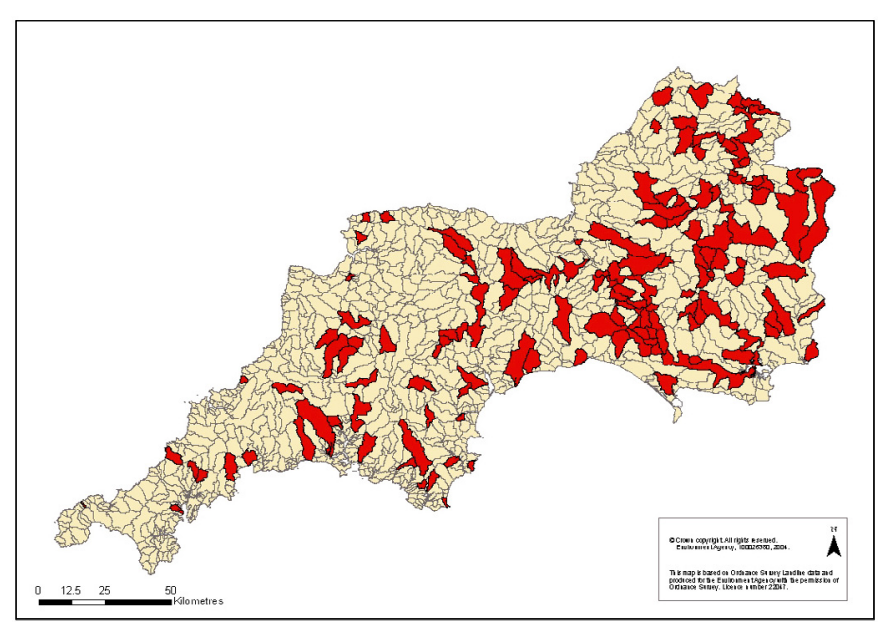

\section{Figure 15}

Crayfish distribution in waterbody catchments in South-West England. a - Approximate distribution of Austropotamobius pallipes in 1975. $b$-Distribution of Austropotamobius pallipes in 2009 (excluding recently translocated populations). c - Distribution of NICS, mainly Pacifastacus leniusculus, in 2009.

\section{Figure 15}

Distribution des écrevisses dans les bassins versants du sud-ouest de l'Angleterre. a - Distribution approximative d'Austropotamobius pallipes en 1975. b - Distribution d'Austropotamobius pallipes en 2009 (excluant les populations déplacées récemment). c - Distribution de NICS, principalement Pacifastacus leniusculus, en 2009. 
specifically including the loss of some of the most historically and numerically important populations in the region in the early/mid 2000s. Bristol Conservation and Science Foundation based at Bristol Zoo Gardens are leading this partnership, which works at a landscape scale across the region (Nightingale et al., 2009). This builds on work undertaken by Avon Wildlife Trust and the Environment Agency and has thus far resulted in the translocation of crayfish from two threatened populations to five new ark sites (one stillwater and four streams). These ark sites now hold more than one fifth of the remaining populations of $A$. pallipes in the whole of South-West England. The first of these was set up in 2006 (Sibley et al., 2007). Further locations across the region are currently under consideration. The invertebrate conservation trust Buglife (www.buglife.org.uk) are providing guidance on the use of aggregate sites (Kindemba and Whitehouse, 2009) that will be examined using the criteria of Peay (2009) as to their suitability for crayfish introductions. Many quarry sites in other regions of Britain are also being considered as ark sites.

\section{$>$ FRANCE}

According to Changeux (2003), the national surveys of crayfish species distribution performed in France since 1977 by the Conseil Supérieur de la Pêche, show that the indigenous species ( $A$. pallipes, $A$. astacus, $A$. torrentium) are either rare, or in decline; while the introduced species (O. limosus, $P$. leniusculus, $P$. clarkii, A. leptodactylus), are increasing. The banning of the transport of live introduced species, except for $A$. leptodactylus, has not stopped this process, especially the rapid propagation of $P$. leniusculus, which has been responsible for a number of crayfish plague outbreaks. Legal protection has been provided for a range of indigenous species and habitats in France, with the setting up of 55 habitat decrees and 154 Natura 2000 zones with their management plans.

At the regional level Bramard et al. (2006) analysed surveys carried out in the PoitouCharentes Region (Departments of Deux-Sèvres, Vienne, Charente, Charente-Maritime) from 1978 to 2003 and revealed a large-scale disappearance of $A$. pallipes populations and the alarming spread of non-indigenous species such as $P$. clarkii and $P$. leniusculus. In the past $A$. pallipes was widely distributed in the Deux-Sèvres department and well represented throughout the departments of Vienne and Charentes. By 2003, they were mostly found in the Deux-Sèvres department, with only a few isolated populations in the other parts of the region. In 1978, 137 populations of $A$. pallipes were recorded in the region. In 1988, 120 populations were found and by 1995 only 81 populations existed in the region, a loss of more than $30 \%$ of crayfish populations in just seven years. In 2003 , only 45 populations were recorded, representing only $32 \%$ of the 1978 number. Most of the disappearances of crayfish are unexplained. The main known causes for the loss of crayfish populations in the region are crayfish plague, the introduction of NICS, habitat degradation and pollution. Pesticides have been implicated in the loss of a few populations, including one in the Crochet stream (Vienne), where the chemicals lambda cyanlochtrine and isoproturon were identified. Organic pollution (farm waste) was also found to be the cause for the loss of at least two populations. At least two populations in the Deux-Sèvres department disappeared following the creation or the maintenance of a pond. The occurrence of crayfish plague was confirmed in the St Christophe river (Deux-Sèvres) (Neveu and Bachelier, 2002) and suspected in three other rivers in 2001. Drought can also cause the loss of a population. During summer 2003, an unprecedented heat wave hit France and two crayfish sites in the Vonne catchment (Poitou-Charentes) completely dried out. Introduced in 1978 to the Vienne department, P. leniusculus now occurs in 28 locations, which are situated in the headwaters of rivers and result from human translocations and natural colonization. The first record of $P$. clarkii was in 1988 in Charente-Maritime department; since then it has spread through most of the hydrographic basin of this department. Orconectes limosus has been widely distributed in the main rivers of the region for almost a century (Arrignon, 1997). One example of cohabitation between O. limosus (dam brook) and $A$. pallipes occurs in Rourie Brook, where a strong population of $A$. pallipes exists. At a regional scale, a second good example is the Burgundy where Lerat et al. (2006) provide 
detailed information about the geographical distribution of $A$. pallipes since 2000; 893 stations have been sampled, from 593 streams and $A$. pallipes has been found in 128 small rivers, and $A$. astacus in only two streams and two ponds. Four non-indigenous species have also been recorded, i.e. A. leptodactylus, O. limosus, P. leniusculus, and P. clarkii. In half of the stations where $A$. pallipes was recorded during the last 30 years it is no longer present. In Burgundy, the $A$. pallipes populations are not very rare but very isolated as in Poitou-Charentes.

According to Collas et al. (2007) the last national survey conducted in 2006 shows the same trend and the situation of the three indigenous species is considered alarming: $A$. torrentium and $A$. astacus are close to extinction, and $A$. pallipes, with mortalities observed in 47 departments, can now only be found in the uppermost parts of the watersheds. These mortalities are due not only to disease, but also to the first signs of climatic changes, i.e. heat-waves and droughts observed in 2003 and 2008, the consequences of which have been analyzed by Renai et al. (2008); and the pressure of non-indigenous species, which are still expanding their range. Both $P$. leniusculus and $P$. clarkii showed their strongest geographical expansion during the 2001-2006 period. Everywhere they appear to be very strong competitors; being more aggressive; resistant to disease, although there are outbreaks of disease at times associated with either a chronic or epizootic mortality (Edgerton et al., 2004); and are able to colonize varied environments. They are in the process of colonizing new departments, new watersheds, and eliminating indigenous species.

\section{$>$ ITALY}

The complexities of the taxonomy and nomenclature of the Italian white-clawed crayfish have been reviewed by Manganelli et al. (2006). There is a general consensus to define the taxon as a species complex. By molecular studies, Fratini et al. (2005) were the first to clearly show that in Italy $A$. pallipes was comprised of two species i.e. italicus and pallipes, with italicus having four subspecies, i.e. A. i. carinthiacus, $A$. i. italicus, $A$. i. meridionalis and $A$. i. carsicus. Therefore, Italy may be considered a "hot-spot" for the genetic diversity of the European crayfish Austropotamobius. The occurrence of five taxonomic units of this threatened crayfish in Italy clearly suggests that any conservation programme and re-introduction plan should refer to the geographic distribution of each unit to ensure the preservation of independent genetic pools. Bertocchi et al. (2008a) have attempted to characterize A. pallipes and A. italicus by morphometric means, but they state that the issue surrounding their taxonomic status has not yet been resolved and that the confused taxonomy may hamper attempts to conserve indigenous crayfish in Italy.

Fragmentation of populations is due to continuous effects of habitat destruction and degradation, but other threats to the survival of $A$. pallipes complex populations include diseases, notably crayfish plague carried by $P$. leniusculus and $P$. clarkii, interspecific competition with NICS and with the indigenous river crab (Potamon fluviatile Savigny), water pollution, overexploitation, and poaching. In Italy, the decline is about $74 \%$ over the last 10 years based on data from Nardi et al. (2005), Füreder et al. (2003), and Renai et al. (2006).

In addition to those mentioned above there have been many surveys of the distribution, or population biology and/or impact of the Italian ICS A. pallipes/italicus and NICS, O. limosus and $P$. clarkii, particularly in central, north-east and north-west provinces, e.g. by Nardi et al. (2005), Chiesa et al. (2006), Fea et al. (2006), Ferri et al. (2006), Gherardi (2006), Gherardi and Lazzara (2006), Gherardi and Acquistapace (2007), Scalici and Gherardi (2007), Ligas (2008), Bertocchi et al. (2008b), Polloni and Ghezzi (2008) and Scalici et al. (2008).

Figure 16a shows that except in the south $A$. pallipes/italicus occurs in most Italian provinces. Figure $16 \mathrm{~b}$ clearly shows how the distribution by province of $P$. clarkii is now almost as great as that of $A$. pallipes/italicus, and that it even occupies provinces in Sicily and Sardinia not occupied by the ICS. 


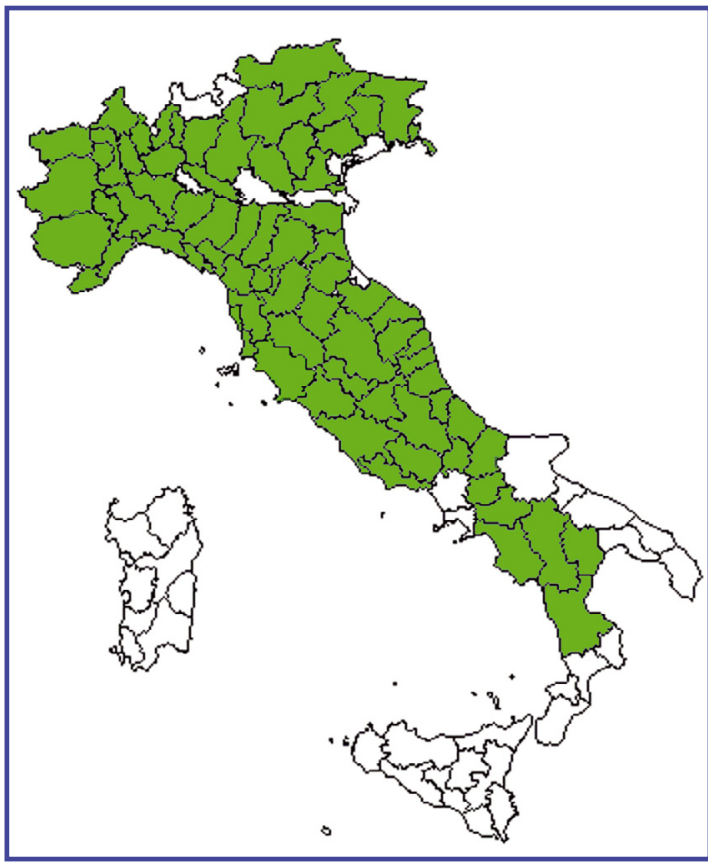

(a)

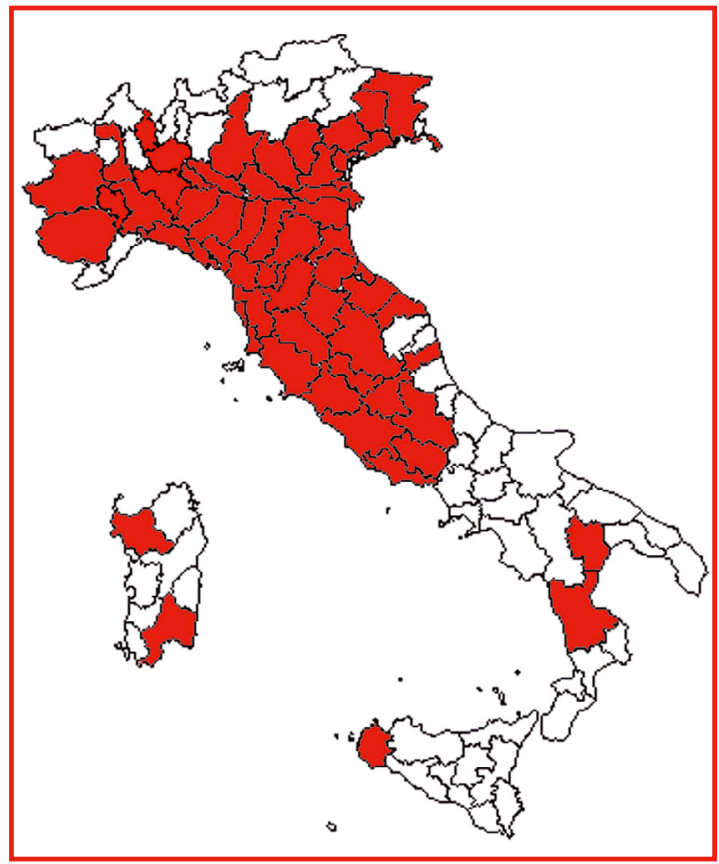

(b)

Figure 16

$a-$ Distribution of the Austropotamobius pallipes species complex in Italian provinces. $b$ - Distribution of Procambarus clarkii in Italian provinces. Reproduced with permission from Füreder (2009).

Figure 16

a - Distribution du complexe d'espèces d'Austropotamobius pallipes dans les provinces italiennes. b - Distribution de Procambarus clarkii dans les provinces italiennes. Reproduction autorisée d'après Füreder (2009).

\section{>IBERIAN PENINSULA}

Austropotamobius pallipes was at one time widespread and quite common in the lberian peninsula, particularly in the north and north-east (Asturias to Leon) and highlands of the south (Holdich et al., 2006). Its origin is in dispute, largely due to differences in interpretation of different genetic techniques. Examination of mtDNA by RFLP found that Spanish white-clawed crayfish share a haplotype with those from northern Italy, suggesting that they were originally translocated from Italy (Grandjean et al., 2001). More detailed work confirmed this hypothesis (Diéguez-Uribeondo et al., 2008). However, using RAPD analysis Beroiz et al. (2008) refute this, finding genetic variability as high in Spain as in other European regions. The southern populations are also morphologically distinct (Gil-Sanchez and Alba-Tercedor, 2006). Some publications therefore refer to Spanish populations as A. italicus (e.g. Martinez et al., 2003). Here they will be considered as part of the A. pallipes species complex.

With the introduction of two North American species into the Iberian peninsula, first, $P$. clarkii in 1973, and then P. leniusculus in 1974 (Habsburgo-Lorena, 1979), the fate of white-clawed crayfish was effectively sealed. Today this crayfish is believed extinct in Portugal (Holdich et al., 2006; Machino and Holdich, 2006) and only remnant populations remain in Spain, chiefly in Atlantic regions of Asturias, Girona and Pais Vasco, Navarra, Castilla and Leon, Cuenca and Granada. As elsewhere when NICS have ousted ICS from the majority of their habitat, $A$. pallipes is now restricted in Spain to small headwater streams and springs (Martinez et al., 2003).

In Cuenca, in the south midlands and enjoying a Mediterranean climate, white-clawed crayfish were formerly quite common in limestone and dolomitic catchments, supporting one of 
the most important crayfisheries in Spain (Torre and Rodriguez, 1964). However, most of the populations in Cuenca had disappeared by 1985 (Martinez et al., 2003), as evidenced from surveys carried out in 1984, 1986, 1990, 1994 and 1998. The number of populations has decreased slightly since 1990 , with an annual loss of $1.5 \%$, but some of the most important populations have disappeared since then. Pacifastacus leniusculus was first stocked in Cuenca in 1986, but no new populations were seen until 1994, about the time when this species was opened to fisheries in some Spanish rivers (Alonso et al., 2000). In 2000 a new province-wide survey detected $A$. pallipes in two areas, comprising just 35 sites out of 259; the rest had no crayfish and of these, 27 were dry. Martinez et al. (2003) analyse the underlying environmental situation.

A similar picture has been seen in other Spanish regions. A 3-year programme of conservation and management was developed for $A$. pallipes in Andalucia (southern Spain) in 2002, where the species was formerly widely distributed (Alonso et al., 2000) but from the 1980s a strong decline in the area occupied was noted, related to expansion of $P$. clarkii, drought and other causes (Gil-Sanchez and Alba-Tercedor, 2006). The management programme encompassed first surveys to delimit the extant populations and their mapping using GIS, then controls against disturbance and habitat degradation, and finally restocking in suitable sites.

In Castilla-Leon A. pallipes was described as close to extinction by the early 1990s (Carral et al., 1993), while its decline in Navarra has been attributed to human dispersal of plaguecarrying $P$. leniusculus (Diéguez-Uribeondo, 2006a). The emphasis since then was on conserving the remaining indigenous stocks and restocking suitable sites through captive breeding and other measures, while concurrently developing an acceptable astacid harvest with introduced P. leniusculus (Reynolds et al., 1992).

As a result of its decline, $A$. pallipes is now listed as threatened in different regions, and was protected in National legislation in 2003 (Martinez et al., 2003).

\section{$>$ SWEDEN}

The Swedish example is significant, as Sweden leads Europe in seasonal consumption of crayfish, and the associated trade and commerce is important to the economy.

Starting in 1907 there were unexplained mortalities and declines in Swedish populations of $A$. astacus. The cause eventually turned out to be crayfish plague and up to the present more than 7000 mortalities have been registered showing the hallmarks of crayfish plague (Bohman et al., 2006). An involved and interested public looked for solutions. By the 1950s the search was on for a gastronomically comparable species that would be an "ecological homologue", which would bolster up the declining indigenous stocks, that were down to $50 \%$ at the end of the 1950s. Another desired feature of the replacement species was that it should be "immune" to the crayfish plague. The answer seemed to have been found in the signal crayfish $P$. leniusculus from Western USA; probably without realizing that it was a chronic carrier of crayfish plague. First introductions to Sweden were made from California in 1959 and then juveniles were released from captive breeding stock into wild in the 1960s (Holdich et al., 2006). Secondary introductions were made from Swedish stocks across Europe. However, by 1998 an estimated 95\% of populations of $A$. astacus in Sweden had been lost to plague and pollution over the last 100 years and it was now indisputable that $P$. leniusculus carry and spread the plague. In 2007 alone there were 439 outbreaks of crayfish plague, and in 2008 there were at least 4000 populations of $P$. leniusculus compared to less than 1000 of A. astacus, a decrease of more than 500 in only eight years (Edsman and Schröder, 2009) (Figures 17a and 17b).

Economically, $A$. astacus today still fetch more than twice the price compared to $P$. leniusculus, although they make up a declining percentage of the catch in southern Sweden. Public and official attitudes are changing, and the continued spread of $P$. leniusculus across Sweden is viewed with alarm, although today it is entirely the work of illegal translocations by local people who misleadingly believe in the superiority of $P$. leniusculus despite lower prices being 


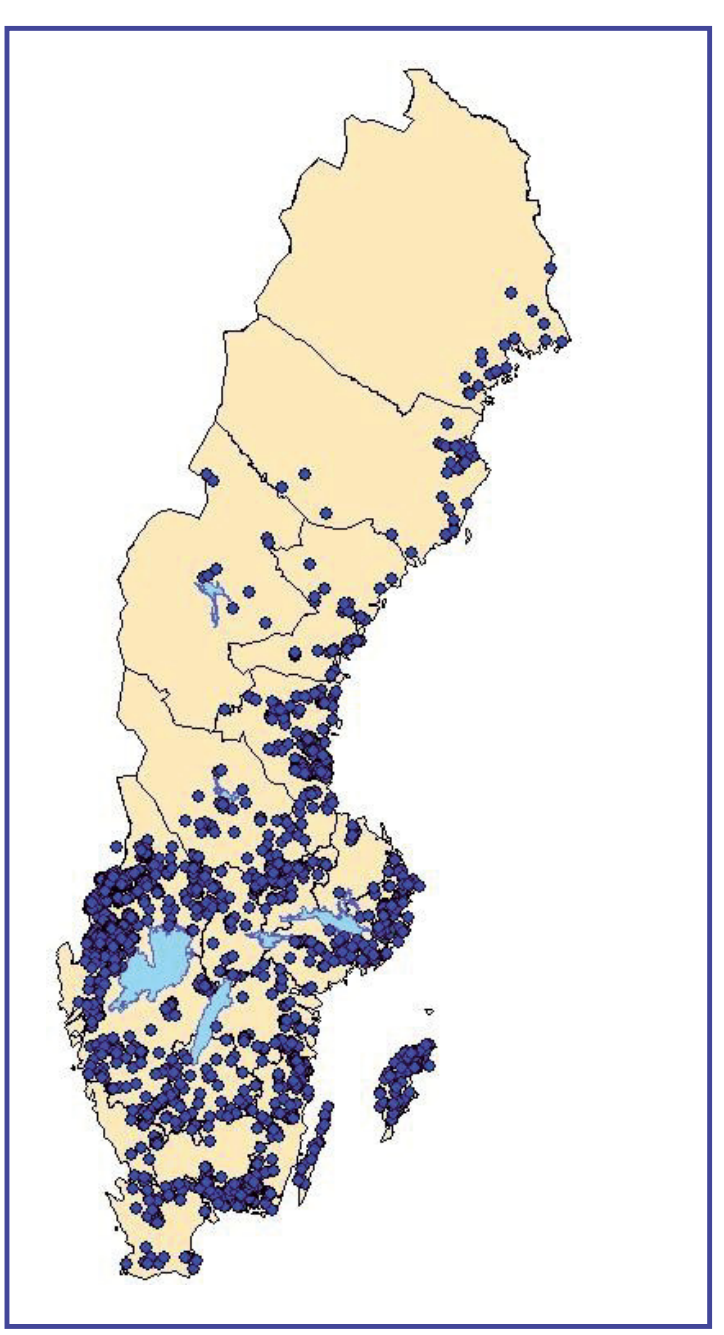

(a)

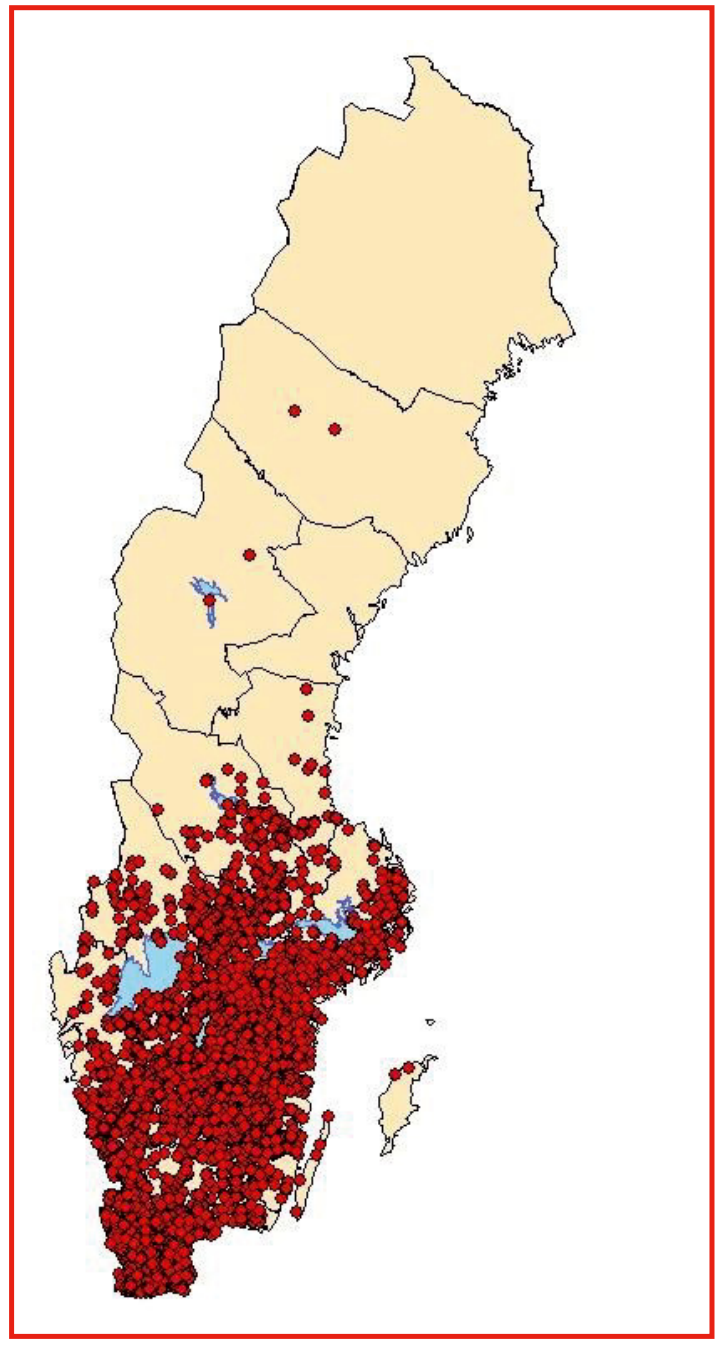

(b)

Figure 17

a - Distribution of Astacus astacus in Sweden in 2008 (1000 localities, a decrease of more than 500 in eight years). $b$ - Distribution of Pacifastacus leniusculus in Sweden in 2008 (> 4000 localities). Reproduced with permission from Edsman and Schröder (2009).

\section{Figure 17}

a - Distribution d'Astacus astacus en Suède en 2008 (1000 localités, un déclin de plus de 500 en huit ans). b - Distribution de Pacifastacus leniusculus en Suède en 2008 (> 4000 localités). Reproduit avec la permission d’Edsman et Schröder (2009).

fetched. In northern Sweden at least, $A$. astacus survive and reproduce better than $P$. leniusculus (Edsman, pers. comm.) as has also been found in Finland by Heinimaa and Pursiainen (2008). In a continuing attempt to protect stocks of $A$. astacus Swedish legislation has now reverted to banning all live imports of crayfish (see below). This decision was long in gestation, but when it came it reflected the reality that even in a free-trade Europe, environmental legislation was now seen as stronger than trade legislation. 


\section{$>$ FINLAND}

Jussila and Mannonen (2004) have described the crayfish situation in Finland. Two commercially valuable species are present, i.e. A. astacus and P. leniusculus. Astacus leptodactylus also occurred in some eastern lakes; however, Mannonen (2009, pers. comm.) believes that these no longer exist. Astacus astacus is widespread in the lower half of the country and has traditionally been stocked into most of the suitable water bodies since the discovery of its commercial value 150 years ago. Originally the species distribution reached the level of $62^{\circ} \mathrm{N}$, but has until now been introduced up to the level of $67^{\circ} \mathrm{N}$ (Westman, 1973). There is a tradition for moving crayfish from one place to another so that the distribution of $A$. astacus has mainly been created by man in the last 100 years (Mannonen, 2009, pers. comm.). In the past 20 years there have been around 10-15 crayfish plague outbreaks in $A$. astacus populations annually, but in the past years only about $30 \%$ of them have been caused by Pacifastacus-type plague, most of the outbreaks still represent the original old type of plague, which was present before the introduction of $P$. leniusculus and which caused devastation throughout populations of ICS in Europe from the 1860s onwards (Alderman, 1996; DiéguezUribeondo, 2006b). Due to mass mortalities caused by crayfish plague and other factors many water bodies have been restocked a number of times. As in Sweden, P. leniusculus was introduced from the 1960s into the 1990s to supplement stocks. The official crayfish strategy was to try and confine $P$. leniusculus to waters in southern Finland and discourage farming of the species outside this region. Due to many unsuccessful re-introductions of $A$. astacus after the plague, the popularity of $P$. leniusculus has increased, and there have been many unlicenced stockings resulting in a spreading of the species northwards, which increases the number of plague outbreaks in the country. Most of the introduced $P$. leniusculus populations have shown signs of infections or really are infected by the plague, although some stocks in the south are thought to be plague-free, some having co-existed with $A$. astacus for many years (Westman et al., 2002). Heinimaa and Pursiainen (2008) examine the factors that determine the northerly distribution limits to $P$. leniusculus introductions in Finland with a view to avoiding any non-viable stocking attempts and for the protection of the indigenous $A$. astacus populations. Due to the adverse impact that $P$. leniusculus is having on $A$. astacus a worst-case scenario is that there will not be any commercially viable $A$. astacus populations in Finland 30 years from now.

\section{> COMMENTS ON SOME OTHER COUNTRIES}

In Belgium, A. astacus is absent from Flanders (Cammaerts, 2009, pers. comm.) but is present in 41 still water sites in Wallonia, although the numbers have been declining $(20 \%)$ since the 1990s; they are also present in six small brooks (9\% decline). Astacus leptodactylus and $P$. leniusculus are slowly extending their ranges and eliminating $A$. astacus in Wallonia.

The Netherlands have two ICS, $A$. astacus and $A$. leptodactylus (introduced in 1977), and six NICS - all from outside of Europe, a number greater than any other European country (Tables I and II; Soes and van Eekelen, 2006). According to Koese (2008, 2009, pers. comm.), there appears to be only one population of $A$. astacus left, although it was formerly widespread in the south-east of the country, and those of $A$. leptodactylus are few. Pacifastacus leniusculus was not recorded until 2004 (Soes and van Eekelen, 2006) and three populations exist in the south and one in the east (Koese, 2009, pers. comm.). Procambarus sp., first recorded in 2004 (Soes and van Eekelen, 2006), was still present in 2008 but difficult to catch as numbers were low. Orconectes limosus, first recorded in 1968 (Soes and van Eekelen, 2006), is widespread but rarely occurs at high densities. Orconectes virilis, first recorded in 2004 (Soes and van Eekelen, 2006), is expanding its range rapidly and could become one of the commonest crayfish in the Netherlands (Soes and Spier, 2006). Procambarus clarkii, first recorded in 1985 (Soes and van Eekelen, 2006), is spreading rapidly with many new records in 2008. Procambarus acutus still has a local distribution, but at very high densities. 
In Germany, on the basis of occurrences in $10 \times 10 \mathrm{~km}$ squares, $A$. astacus and O. limosus are the most wide-spread and common species; $A$. leptodactylus is known from 67 squares, P. clarkii from 15, O. immunis from 11, Procambarus sp. from at least two (calculated from maps supplied by H. Schulz, 2009).

In the Carinthia region of Austria there are three ICS, i.e. A. astacus, $A$. pallipes and $A$. torrentium, and three NICS, i.e. O. limosus, P. clarkii and P. leniusculus (Weinländer and Füreder, 2009). Besides habitat loss caused by human activities it is displacement by $P$. leniusculus that is the reason for the rapid decline of ICS, particularly A. astacus and A. torrentium, in this region. This situation also appears to be occurring in other parts of Austria (Pöckl and Pekny, 2002; Füreder et al., 2009). Wittenberg (2005) provides an inventory of NICS and their threat to biodiversity and the economy in Switzerland.

The current crayfish situation in the Baltic countries of Lithuania, Latvia and Estonia is worthy of comment. There has been some re-establishment of $A$. astacus populations in large mesotrophic lakes in Lithuania, partly due to a decrease in eels and an improvement in water quality. However, $O$. limosus is spreading at a rapid rate through the country and is a major threat to $A$. astacus (Burba, 2009; Burba, 2009, pers. comm.). Although known from an isolated lake in the north in 1994, O. limosus entered the south and south-west of Lithuania from Belarus and the Russian enclave of Kaliningrad in 1995 and took only 10 years to invade almost the whole country. Astacus leptodactylus is distributed in the north-east of the country and can be found for sale in shops. Pacifastacus leniusculus was introduced illegally into a river in the east of the country in 2002 . There have been many mass mortalities of crayfish in Lithuania since 2002, involving A. astacus, A. leptodactylus and O. limosus, although it is not known if these were due to crayfish plague due to a lack of testing facilities. Procambarus sp. is popular in the aquarium trade. In Latvia to the north of Lithuania, work is underway to develop aquaculture facilities for $A$. astacus (Arens, 2009, pers. comm.). Three non-indigenous species occur in the country, i.e. A. leptodactylus from Russia, Belarus and Lithuania; $P$. leniusculus from Lithuania; and most recently $O$. limosus from Lithuania. In 2004, A. astacus was the dominant crayfish species in Latvia, it was found in 220 out of 258 localities (Taugbøl et al., 2004). Most of these localities are lakes (175), but many crayfish populations were also found in rivers and streams (66). A few populations were found in reservoirs, ponds and gravel-pits. In 26 localities $A$. leptodactylus was the only species, and $P$. leniusculus was found as the only species in four localities. Astacus astacus and A. leptodactylus were reported to coexist in eight localities. The arrival of $O$. limosus in Latvia may change the balance in the future. Astacus astacus is the only crayfish inhabiting Estonian waters, although a single specimen of $P$. leniusculus was caught in one river in the north in 2008 (Paaver, 2009, pers. comm.). Astacus leptodactylus from Armenia are sold live in shops and there is the potential for them to be released into the wild. There is no commercial fishing for A. astacus and recreational catches are low compared to the early 1900 s and the onset of crayfish plague; a lot of restocking for recreational purposes is being undertaken, and there are around 20 crayfish farms, five of which produce crayfish for consumption (Paaver and Hurt, 2009a). There are many threats to $A$. astacus in Estonia including NICS from surrounding countries, habitat deterioration, pollution, and predation by eels and mink (Paaver and Hurt, 2009b).

In the Czech Republic, Vlach et al. (2009) state that $A$. torrentium, which is considered critically endangered and is protected by national law (Kozák et al., 2002), is known from 30 localities (21 in Kozák et al., 2002). Astacus astacus appears to be declining as many historical records have not been confirmed in recent surveys, while $A$. leptodactylus has a scattered distribution, but may be less frequent than previously assumed due to misidentification with A. astacus. Astacus leptodactylus was introduced from the Dniester watershed for aquaculture purposes and despite being a relatively new addition it is protected as an endangered species. All three have been affected by crayfish plague outbreaks in recent years. Although there were only two suspected mortalities due to crayfish plague in the second half of the 20th century, there were five between 2004 and 2007, and it is thought that O. limosus (introduced in 1989) is the primary reservoir of crayfish plague in the Czech Republic (Kozák 
et al., 2000a, 2000b; Kozubíková et al., 2006, 2007, 2008, 2009). Populations of ICS are also being affected by localized pollution events and habitat alteration, especially watercourse regulation, mink predation and competition with NICS (O. limosus and P. leniusculus). Pacifastacus leniusculus was introduced for aquacultural purposes in 1980 and now mainly occurs in south-western Moravia near the original site of introduction (Filipová et al., 2006a, 2006b). However, a new population has been found at the border with Germany (Petrusek, 2009). Orconectes limosus is the most widespread invasive species in the Czech Republic, especially in the western part, and is found in a wide variety of habitats. Its presence in the region was first confirmed in 1988 close to the border with Germany, but actually earlier that this in 1960 s it was reported from pools adjacent to the R. Elbe. It invaded the Czech Republic by upstream migration through the R. Elbe (Filipová et al., 2006a; Petrusek et al., 2006). It has been found close to the border with Poland in the north-east, from where it migrated. It has recently been found in south-eastern Moravia close to the border with Slovakia, an area assumed to be devoid of NICS (Petrusek, 2009). As with many other Central and East European countries, Procambarus sp. is popular with hobbyists.

Between 1999 and 2001 a large scale restocking programme for $A$. astacus and A. leptodactylus took place in Poland to try and counteract the decline of these two species; a $60.8 \%$ success rate was recorded (Śmietana et al., 2004). However, Śmietana (2009, pers. comm.) predicts that due to the impact of $O$. limosus, $A$. astacus may be eradicated within the next $2-5$ years. The spread of $O$. limosus is being facilitated by recreational angling where it is used as bait, and by owners of new lakes who put anything into their lakes that will survive, especially crayfish, which are considered as a bioindicator of clean water. Where O. limosus is absent then $A$. astacus survives in small rivers and streams in southern Poland. There were 98 wild and 42 restocked populations of $A$. astacus in 1999, and 89 wild and 12 restocked populations in 2008. There have been two mass mortalities of $A$. astacus in the last five years due to unknown reasons. Astacus astacus is listed as VU (vulnerable) in the Polish Red Data Book of Animals. Astacus leptodactylus is less abundant than A. astacus in Poland and is disappearing faster. It is not included in the Red Data Book but is considered as vulnerable. There were an estimated 64 populations in 1999 and this has decreased to 47 at present. Pacifastacus leniusculus was introduced from Sweden between 1972 and 1979 but the attempt failed; between 1991 and 1992 further introductions were made and now P. leniusculus is an important aquaculture species in the country (Schulz and Śmietana, 2001).

In Croatia the rapid spread of $O$. limosus through the $\mathrm{R}$. Danube catchment is having adverse effects on the populations of $A$. leptodactylus (Faller et al., 2009), as is $P$. leniusculus on $A$. astacus populations in the R. Mura, where they have disappeared from many sites (Hudina and Lucić, 2009). Pacifastacus leniusculus entered Croatia in 2008 via the R. Mura, which borders Hungary and Slovenia and is expected to spread downstream toward the R. Drava (Maguire et al., 2008).

Pârvulescu et al. (2009) have recently recorded the presence of $O$. limosus in the R. Danube from Romania, and there is little to stop it continuing down-river to Bulgaria and the Black Sea. Zaikov and Hubenova (2007) report that there are no NICS in Bulgaria. Three ICS are present, $A$. leptodactylus, $A$. astacus and $A$. torrentium and there are laws to protect each of them. About 20 tonnes per annum of $A$. leptodactylus are harvested, but there is no strong tradition for eating them except on the Black Sea coast.

In Greece, populations of $A$. astacus occur in north-west, north and central parts of the country and $A$. torrentium occurs in northern and north-eastern parts, with a degree of overlapping in its distribution with $A$. astacus in Thessaly and Central Macedonia. Astacus leptodactylus has been recently verified in the River Evros close to the Greco-Turkish border, suggesting that the species should be regarded as indigenous in Greece. Pacifastacus leniusculus forms a well established population in Lake Agras and co-occurs with $A$. torrentium. A mass mortality of $A$. astacus occurred in August 2005 over a 15-km stretch of the main R. Kalamas and its tributaries in north-western Greece (Savvidis, 2005a, 2005b). Despite many signs that it was caused by crayfish plague this could not be verified in the laboratory by Cefas (Centre for the Environment, Fisheries and Aquaculture Science) in the UK. Previous mortalities, thought 
to be due to crayfish plague occurred after the introduction of $P$. leniusculus from Sweden in 1982, and also occurred in the R. Kalamas (1986) as well as in the R. Louros (1987) (Theocharis, 1986).

Šanda and Petrusek (2009) have confirmed the presence of $A$. astacus, $A$. pallipes and $A$. torrentium in Bosnia-Herzegovina, where a number of mass mortalities have been reported despite there apparently being no NICS present. A detailed study of the habitat preferences and level of endangerment to ICS in Serbia and Montenegro based on a 60-year period has been given by Simić et al. (2008). Astacus astacus is the most endangered species in both countries due to pollution, habitat fragmentation, diseases, competition from A. leptodactylus, as well as isolation of populations. Populations of $A$. astacus are also endangered by overfishing in Serbia, but not in Montenegro.

\section{LEGISLATION AND CONSERVATION MEASURES}

The three ICS in Western Europe, A. astacus, $A$. pallipes and A. torrentium, are listed as protected in Appendix III of the Bern Convention. The EC's Habitat Directive, part of Europe's response to the Convention on Biological Diversity at the 1992 Earth Summit in Rio de Janeiro, lists $A$. pallipes under Appendix II and A. astacus, $A$. pallipes and $A$. torrentium under Appendix V. Species listed under Appendix II of the Habitats Directive (Directive for the Conservation of Natural Habitats and Wild Flora and Fauna (92/43/EEC and 97/62/EU)), are those that require the designation of protective sites or special areas of conservation (SACs) that are overseen by the European network - Natura 2000. Austropotamobius torrentium has recently been included in Appendix II. Species listed under Appendix V of the Habitats Directive and Appendix III of the Bern Convention are those whose exploitation or harvesting should be subject to appropriate control in member states.

As mentioned in the introduction to this paper, in 1996 A. astacus, $A$. pallipes and $A$. torrentium were assessed as vulnerable using criterion B2bce+3bcd by the IUCN (Baillie and Groombridge, 1996). These assessments still stand at present (IUCN, 2009), although with the caveat "needs updating". This is in progress (Dewhurst, 2009, pers. com.) and current population estimates indicate that some of these species are likely to change category, however any change in category cannot be interpreted as a decline or increase in abundance since the 1996 assessments. These previous assessments of vulnerable were made on the basis that these species had an extent of occurrence (EOO) of less than $20000 \mathrm{~km}^{2}$; recent calculations of the EOO for each species indicate that they far exceed $20000 \mathrm{~km}^{2}$ and so no longer qualify for listing under criterion $\mathrm{B}$. Both $A$. astacus and $A$. pallipes now qualify for a listing under criterion $A$, which utilizes population data to infer rates of decline over a 10 year period or three generation lengths, whichever is greater. Trends in abundance have been calculated using both presence/absence data, and harvest data. It is, however, acknowledged that calculations of these trends are based on the assumption that rates of decline for parts of a country can be translated into what is happening in the whole country, that the population is equally distributed across the country or has been in the last 10 years, and that the rates of decline that have been obtained from presence/absence data are reasonably indicative or at least conservative estimates, of changes in population numbers. Preliminary results suggest that $A$. pallipes has declined by $\sim 60 \%$ in the UK, $\sim 50 \%$ in France, and $\sim 75 \%$ in Italy over the last 10 years. Population estimates for $A$. astacus indicate declines of $\sim 87 \%$ for Sweden and $\sim 15 \%$ for Finland over the last 10 years. Data on population trends for $A$. torrentium is greatly lacking and so it is unlikely to qualify for a listing under criterion A. As declines are known to be occurring, this species may be listed as Data Deficient with a caveat acknowledging that it is likely to be threatened but data to assess it under the criteria is not available. Based on the available data, the authors of this paper, along with others who took part in discussion of the issue, suggest a revised listing of endangered for $A$. pallipes and to maintain a listing of vulnerable for $A$. astacus.

Legislative controls are one way to protect indigenous crayfish (Reynolds et al., 2006). Legislation may relate to controls on imports and exports, or to protection of indigenous stocks 
and habitats. Fishing regulations may relate to ICS, NICS or both. The relevant legislation relating to freshwater crayfish varies across Europe (Vigneux et al., 2002, Edsman and Śmietana, 2004) and within states (Puky et al., 2005), and its efficacy has been questioned (Holdich and Pöckl, 2005). Variable controls in trans-national catchments, notably the Danube system, are particularly problematic in regard to the spread of species (Puky et al., 2005; Pârvulescu et al., 2009), and European legislation is not strong enough in this regard. There are also problems of enforcement, particularly in internet based trade. Given below are a series of examples of the type of legislation in force in Europe regarding ICS and NICS; space does not permit every country to be dealt with. Further details of the situation in Britain and of that in Austria can be found in Holdich and Pöckl (2005).

In the past decade the situation has changed markedly in Northern Europe, where the ICS $A$. astacus is in decline as NICS (largely P. leniusculus) expand their range. Swedish legislation with restrictions on live crayfish imports was lifted in 1997, but a ban on live imports both from EU and third countries was reinstated in 2003. The Swedish example indicates the new importance at the European level of environmental and conservation legislation over the previously dominant free trade agreements (Edsman, 2004). A revised national action plan for the conservation of $A$. astacus was launched in 2009 and county administrations can now assign special protected areas for $A$. astacus with restrictions on moving live crayfish, fish and gear in and out of the area to avoid spreading the disease crayfish plague. In addition, a budget of 1.5 million $€$ has been allocated for actions such as information, inventories, extermination of illegally introduced $P$. leniusculus populations, reintroduction of $A$. astacus after crayfish plague and habitat improvements. The action plan also states that with NICS readily available, the largest threat is not over-fishing but illegal introductions of plague-carrying $P$. leniusculus by man. Local people that are allowed to catch and benefit from $A$. astacus are also the best protection against illegal stocking of non-indigenous crayfish. The possibility to exploit the crayfish is of major importance in underpinning the will to protect and will involve more people in the task. In Sweden, exploitation, in the form of a sustainable fishery, is considered to be the key to successful conservation of $A$. astacus. Consequently the major part of the budgeted funds will be allocated locally, directly to the fishing rights owners of the lakes and running waters (Edsman and Schröder, 2009).

In Norway, lacking NICS until recently (see above), a law forbids stocking of any freshwater organism without permission from environmental authorities. There is central regulation of crayfish harvesting, involving legal periods, minimum size ICS and legal mesh size on traps. Another law forbids live imports of NICS. In watersheds with crayfish plague local regulations forbid fishing for crayfish and restrict other uses of or activities in the watershed. There are no major changes since 2005 , apart from a local regulation made after the finding of $P$. leniusculus in Telemark.

The Finnish fisheries legislation has notified crayfish since 1920s, and it has been renewed several times. To catch crayfish one needs a governmental fishing licence, and the licence of the water owner. There is no minimum legal size of catchable crayfish. The crayfish season is limited to be from 21st June at noon until the end of October. The legislation is currently being reviewed, but as far as known, no radical changes concerning crayfish will be made. Local Finnish fisheries authorities' crayfish policy is based on the national crayfisheries strategy published in 2000, which includes both $A$. astacus and $P$. leniusculus.

Since 2005 German federal law has not been improved and Germany remains a major hole in the defences against NICS. The ICS $A$. astacus and $A$. pallipes are protected under the Federal Nature Conservation \& Protection Act (NCPA) and Federal Species Protection Ordnance. According to NCPA, the introduction of NICS is not allowed, but all species naturally reproducing over several generations are defined as native or indigenous. Thus, NICS like O. limosus, $P$. leniusculus and other species already established in natural habitats are not specially controlled. The state fisheries laws of some federal states include additional restrictions on stocking of crayfish, e.g. in Bavaria only $A$. astacus is allowed to be stocked in all kinds of waters. 
United Kingdom and Irish legislation differs (Holdich et al., 1999), although the EU Habitats Directive provides some protection in both jurisdictions for the indigenous white-clawed crayfish, A. pallipes. British legislation provides "no-go" areas where NICS may not be introduced, but still allows some importation and movement of non-indigenous stocks, for example the sale of live crayfish over the counter for human consumption, except in Scotland (Bean et al., 2006). In Ireland, fisheries legislation prohibits importation of NICS (Gibson, 1979; Reynolds et al., 2002), to protect the valuable salmonid stocks. Northern Ireland, while being part of the UK, cooperates with the Irish Republic on this. However, UK citizens may assume that all British legislation applies there, and social influences such as some media programmes, which have given a false impression that NICS are already present in the province, further endanger the Irish white-clawed crayfish stocks.

\section{DISCUSSION}

Recent evidence that Europe may be home to 11000 alien species has spurred the European Commission to release its first ever Communication on invasive species (European Commisssion, 2008). The European Environment Commissioner, Stavros Dimas, noted at the launch of the Communication that "the ecological, economic and social consequences of the spread of invasive species for EU countries are serious and need a harmonised response". The Communication, which is currently open for consultation, proposes the development of a European Strategy on Invasive Species. It outlines three potential ways forward, each representing a different level of legislative cost and complexity. The first, and least complex, involves making better use of existing legislation; the second would adapt existing legislation to address invasive species, while the third, and most complex, would develop a dedicated legal instrument. But is this the best way forward? A recent paper published in the journal Science by Hulme et al. (2009) suggests legislation is only part of the answer and that what Europe lacks is appropriate governance and institutional coordination across Member States to tackle the problem of invasions effectively. They state that: "Currently, responsibility for invasive species management sits within too many different European Institutions. These are organizations such as the European Environment Agency (EEA), European and Mediterranean Plant Protection Organisation (EPPO), European Food Safety Authority (EFSA) that rarely communicate with each other and where the topic of invasions is only one of many areas of activity", and "This system is not effective. For example EPPO and EFSA have not seen eye to eye when it comes to assessing the risks to Europe of different alien species, while funding for research and management is often prioritised separately by the different Directorates-General in Brussels. The political, cultural and geographic complexity of Europe makes a single coordinating body a necessity". The authors of the paper, who recently edited the Handbook of Alien Species in Europe (Daisie, 2009; European Invasive Alien Species Gateway, http:// www.europe-aliens.org/) recommend that the European Parliament and Council give serious consideration to the establishment of a single body to bring together invasive species related resources and activities currently dispersed amongst the various European institutions. This body, which they call the European Centre for Invasive Species Management (ECISM), would have a mission to identify, assess and communicate current and emerging threats to the economy and environment posed by invasive species. ECISM would coordinate activities across Member States, building a Europe-wide surveillance system, which could monitor emerging threats, support rapid response and raise public awareness around the issues of invasive species. The idea is sound, but such a Centre would face considerable challenges. For example, the major policy driver of a single EU market for goods and people favours the spread of invasive species, the number of alien species introductions continues to increase year on year, and public awareness of the impact of those species is little more than $2 \%$. Unfortunately, these factors make the formation of such a body all the more challenging and only time will tell if Europe is able to meet that challenge.

It is clear from the above that the development of a trans-national strategy on biological invasions in freshwater is needed; however, as Genovesi (2007) has pointed out the main 
obstacles to this are: lack of transboundary cooperation, limited ability to detect species early enough, ineffectual or delayed responses to the early stages of invasions, limited tools for eradicating or controlling invasive species in freshwater, the deficiencies and inconsistency of legal provisions and the difficulty of trade regulation - all of which is very relevant to the NICS situation. The EU strategy on invasive species highlights the ever-growing problem of invasive alien species in Europe and emphasises the importance of early detection of potentially invasive species and rapid action to eradicate them while it is still economically and environmentally effective (European Commisssion, 2008). This is very relevant to the "New NICS" situation and also to the expansion of "Old NICS". Perhaps most worrying in the context of the survival of ICS in Europe is the rapid spread of $O$. limosus and $P$. leniusculus through the rivers in Eastern Europe. Orconectes limosus has reached Romania through the R. Danube (Pârvulescu et al., 2009) and P. leniusculus has reached the R. Mura in Croatia (Hudina and Lucić, 2009). This does not bode well for stocks of $A$. astacus and A. leptodactylus in these regions and further east, although because of its habitat preferences $A$. torrentium may be protected to some extent. As of yet there have been no reports of mortalities caused by crayfish plague in these easterly regions, but there have been many unexplained mortalities. The rapid spread of a "New NICS" is well illustrated by that of O. immunis in the upper R. Rhine in Germany, even to the extent of displacing an established "Old NICS", O. limosus (Chucholl et al., 2008; Chucholl, 2009). Another worrying fact is the popularity of Procambarus sp. amongst hobbyists, particularly in Central and Eastern Europe.

In their discussion on the future of ICS in Europe, Taugbøl and Skurdal (1999) predicted that if effective conservation plans were not put in place, then in 100 years time it might be that all watersheds suitable for crayfish in Europe are occupied by NICS, and all ICS are critically endangered and survive only in a few protected localities. To avoid this scenario and to ensure that some countries remain free from NICS and retain extensive populations of ICS they suggested the following actions: restoration of aquatic habitats; protection of ICS as a national aim; obtaining a good knowledge of the status and distribution of crayfish; identifying and establishing "native crayfish areas", preventing the further spread of NICS, implementing effective legislation, fostering cooperation and coordination, re-establishing ICS where they have been eradicated, informing the public, and exploiting ICS - these actions were displayed in a conceptual model similar to that in Figure 18. Whilst most of the actions are commendable the last one is contentious. Taugbøl and Skurdal (1999) and Taugbøl (2004) maintain that exploitation and protection are closely linked, as those who exploit are usually concerned about the resources and will protect them (see Sweden under Legislation). This may be the case for countries where there is a strong tradition of harvesting and consuming crayfish, but not where the ICS are protected from harvesting by law, as in the British Isles. In light of what was happening in Europe in the 1990s, Taugbøl and Skurdal (1999) suggested that the setting up of "native crayfish areas" (NCAs) was of prime importance for ensuring the future of ICS. These could be as large as a country, a region, a watershed, or even a single watercourse or waterbody. They highlighted Ireland and Norway as being suitable NCAs for A. pallipes and $A$. astacus respectively as both countries were at the time free of NICS. Unfortunately, Norway has since had a number of incursions of $P$. leniusculus into its waters, although in one case they have may have been eradicated (Johnsen et al., 2007; Johnsen and Vrålstad, 2009). Ireland retains its status as the only country solely occupied by $A$. pallipes and with no NICS (Gallagher et al., 2005; Reynolds, to appear). In the 2000s this suggestion has become a reality, albeit only at the level of single populations so far. As mentioned above, in South-West England (Sibley et al., 2007) and also elsewhere in Britain (Peay, 2009), secure locations or "ark sites" are being developed into which threatened populations of ICS are being moved. The concept of "ark sites" is also being taken forward in Northern Ireland (Horton, 2009; Reynolds, to appear). Sweden is in the process of setting up protected areas for A. astacus, including the whole of the island of Gotland (Edsman, 2009, pers. comm.).

The conceptual model shown in Figure 18, shows the different actions necessary for protection of ICS in Europe, under two main groupings: general management, including implementing legislation, developing public education strategies and coordination, and specific 


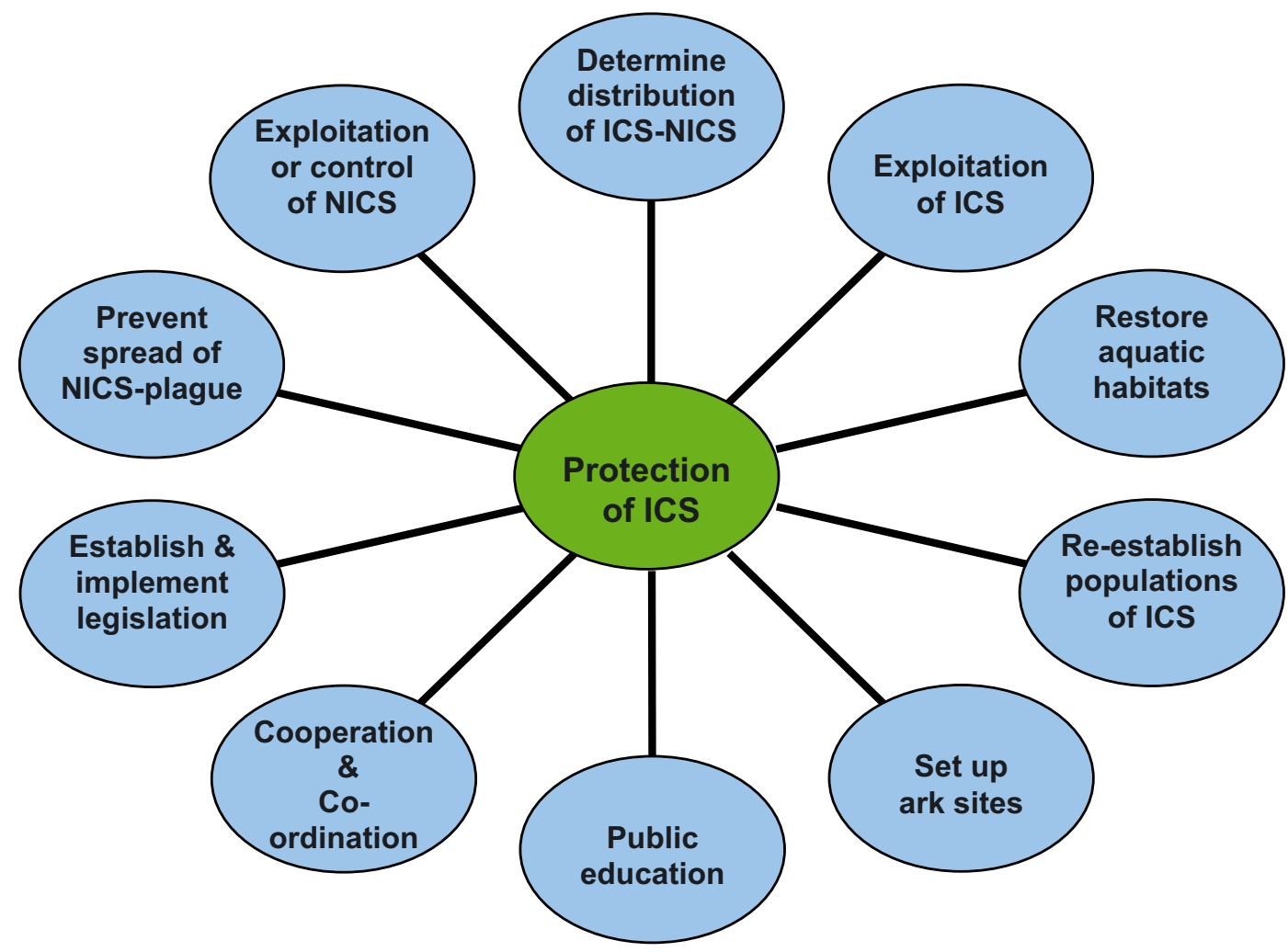

Figure 18

Conceptual model showing paths that could be taken to try and protect ICS. Modified from Taugbel and Skurdal (1999).

Figure 18

Modèle conceptuel montrant les solutions qui peuvent être choisies pour protéger les ICS. Modifié d'après Taugbøl et Skurdal (1999).

actions - distribution surveys, site protection and habitat restoration, fisheries controls for ICS and NICS, and actions to restrict NICS and the spread of plague. This model can be applied to the actions being carried out in South-West England (see above), with the exception that the ICS are not exploited but are protected. The model has also been suggested as a basis for conserving ICS in Austria (Pöckl and Pekny, 2002). In the decade since Taugbøl and Skurdal published their guidelines, a number of things have changed, thanks to greater activity in Europe (e.g. EU Habitats Directive, CRAYNET) and in EU member states, particularly the UK (meetings, initiatives such as no-go areas and ark sites). Legislation has been tightened, and the attitudes of EU and member states to international treaties dealing with the environment and with free trade have changed somewhat. In Scandinavia, the Swedish story, involving relaxation of legislation in 1997 to permit live crayfish imports and their eventual reimposition in 2003, is described by Edsman (2004), while the value of exploitation as a conservation tool is emphasized by Taugbøl (2004). A number of countries have set up national plans for their ICS and NICS, e.g. Austria (Pöckl and Pekny, 2002) and Switzerland (Stucki et al., 2005; Hefti and Stucki, 2006). In France, during the recent World Wetlands Day (2nd February 2009, the anniversary of the signing of the Ramsar Convention on Wetlands in 1971) an opportunity for governments, organizations, and citizens to undertake large and small actions intended to raise public awareness of wetland values, a motion was raised about an action plan against $P$. clarkii and other NICS. This motion was signed by scientists, managers and stakeholders calling for national action for effective legislation, a network of managers to detect the arrival of new NICS, and a network of scientists and managers 
to evaluate the resulting disequilibrium of ecosystems and control the populations; finally, it demanded greater information for the public.

Public education into the dangers of spreading NICS is increasing at a national and local level. Directed surveys have established the distribution of ICS and NICS in Europe up to 2006 (Souty-Grosset et al., 2006), and research in the UK has shown the difficulty of eradicating NICS stocks (Peay et al., 2006). An attempt to eradicate them from the River Clyde in Scotland cost over $£ 100000$ but was unsuccessful (Collins, 2006). Prophylactic measures to prevent the spread of plague, already promoted in Scandinavia (e.g. Taugbøl et al., 1993) are now better and more widely established as transmission of the plague organism has become better understood (Diéguez-Uribeondo, 2006b). The real problem is in the persistent power of myths about the superiority of the signal crayfish, $P$. leniusculus, and the main culprit remains the illegal transfer of NICS into waters containing indigenous crayfish stocks particularly in Scandinavia and Britain.

Whether or not European ICS survive the next 100 years is up to each country and the action it takes, but it should be born in mind that no action may well impinge on the survival of ICS in neighbouring countries. Territories without invading populations of NICS, or in early stages of the problems could do well to look at the mixed experiences of Britain in trying to protect its single ICS, A. pallipes, in the face of an ever growing number of NICS (Holdich and Sibley, 2009; Sibley et al., 2009; Peay et al., to appear).

\section{ACKNOWLEDGEMENTS}

Special thanks goes to Chris Lukhaup (Germany) for allowing us to use his excellent photographs, to Lennart Edsman (Sweden) and Leopold Füreder (Austria) and for permission to use their maps, and to Nadia Dewhurst (UK) for information on the IUCN's position. The authors also wish to thank the following for their help in providing information on crayfish distribution: Anatoly Alekhnovich (Belarus), Augusts Arens (Latvia), Aloyzas Burba (Lithuania), Roger Cammaerts (Belgium), Chris Chucholl (Germany), Ana Costa (Portugal), Javier Diéguez-Uribeondo (Spain), Christoph Dümpelmann (Germany), Adam Ellis (UK), Lennart Edsman (Sweden), Gianiuca Fea (Italy), Leopold Füreder (Austria), Francesca Gherardi (Italy), Fernando Alonso Gutierrez (Spain), Daniel Hefti (Switzerland), Philipp Hirsch (Germany), Stein Ivar Johnsen (Norway), Emmanuil Koutrakis (Greece), Pavel Kozák (Czech Republic), Chris Lukhaup (Germany), Yoichi Machino (Japan), Ivana Maguire (Croatia), Alexandra Marçal (Portugal), Andreas Martens (Germany), Tiit Paaver (Estonia), Lucian Pârvulescu (Romania), Stephanie Peay (UK), Costas Perdikaris (Greece), Adam Petrusek (Czech Republic), Manfred Pöckl (Austria), Miklós Puky (Hungary), Markku Pursiainen (Finland), Gérard Schmidt (Luxembourg), Holger Schulz (Germany), Christian Skov (Denmark), Przemek Śmietana (Poland), Mikhail Son (Ukraine), Eduard Stloukal (Slovakia), Thomas Stucki (Switzerland), Trond Taugbøl (Norway), and Angel Zaikov (Bulgaria). Finally, thanks are due to two anonymous referees for their input.

\section{REFERENCES}

Abrahamsson S., 1973. Methods for restoration of crayfish waters in Europe - the development of an industry for production of young Pacifastacus leniusculus. Freshwater Crayfish, 1, 203-210.

Ackefors H., 1999. The positive effects of established crayfish introductions in Europe. In: Gherardi F. and Holdich D.M. (eds.), Crayfish in Europe as alien species - how to make the best of a bad situation?, A.A. Balkema, Rotterdam, 49-61.

Ahern D., England J. and Ellis A., 2008. The virile crayfish, Orconectes virilis (Hagen, 1870) (Crustacea: Decapoda: Cambaridae), identified in the UK. Aquatic Invasions, 3, 1, 102-104.

Alcorlo P., Otero M., Crehuet M., Baltanás A. and Montes C., 2006. The use of the red swamp crayfish (Procambarus clarkii, Girard) as indicator of the bioavailability of heavy metals in environmental monitoring in the River Guadiamar (SW, Spain). Sci. Total Environ., 366, 1, 380-390. 
Alderman D.J., 1996. Geographical spread of bacterial and fungal diseases of crustaceans. Rev. sci. tech. Off. Int. Epiz., 15, 2, 603-632.

Alderman D.J. and Polglase J.L., 1988. Pathogens, parasites and commensals. In: D.M. Holdich and R.S. Lowery (eds.), Freshwater crayfish: biology, management and exploitation, Croom Helm, London, 167-212.

Alekhnovich A., 2006. Production of a narrow-clawed crayfish population of Astacus leptodactylus (Eschscholtz, 1823) in Belarussian waterbodies. Crayfish News: IAA Newsletter, 28, 2, 5-7.

Alonso F., Temino C. and Diéguez-Uribeondo J., 2000. Status of the white-clawed crayfish, Austropotamobius pallipes (Lereboullet, 1858) in Spain: distribution and legislation. Bull. Fr. Pêche Piscic., 356, 31-54.

Aquiloni L., Becciolini A., Berti R., Porciani S., Trunfio C. and Gherardi F., 2009. Managing invasive crayfish: use of X-ray sterilisation of males. Freshwat. Biol., 54, 1510-1519.

Arens A. and Taugbøl T., 2005. Status of crayfish in Latvia. Bull. Fr. Pêche Piscic., 376-377, 519-528.

Arrignon J.C.V., 1997. Status of foreign crayfish in France. Freshwater Crayfish, 11, 665-670.

Baillie J. and Groombridge B. (eds.), 1996. 1996 IUCN Red List of Threatened Animals, IUCN, Gland.

Baitchorov V.M. and Giginiak U.G., 2009. Spiny-cheek crayfish Orconectes limosus (Rafinesque, 1817) in Belarus. Crayfish News: IAA Newsletter, 31, 2, 7-8.

Bean C.W., Maitland P.S. and Collen P., 2006. Crayfish in Scotland: A review of current status and legislative control. Freshwater Crayfish, 15, 220-228.

Beran L. and Petrusek A., 2006. First record of the invasive spiny-cheek crayfish Orconectes limosus (Rafinesque, 1817) (Crustacea: Cambaridae) in the Bohemian Forest (South Bohemia, Czech Republic). Siva Gabreta, 12, 3, 145-146.

Beroiz B., Callejas C., Alonso F. and Ochando M.D., 2008. Genetic structure of Spanish white-clawed crayfish (Austropotamobius pallipes) populations as determined by RAPD analysis: reasons for optimism. Aquat. Conserv., 18, 2, 190-201.

Bertocchi S., Brusconi S., Gherardi F., Buccianti A. and Scalici M., 2008a. Morphometrical characterization of the Austropotamobius pallipes species complex. J. Nat. Hist. , 42, 31-32, 2063-2077.

Bertocchi S., Brusconi S., Gherardi F., Grandjean F. and Souty-Grosset C., 2008b. Genetic variability in the threatened crayfish Austropotamobius italicus in Tuscany: implications for its management. Arch. Hydrobiol., 173/2, 153-164.

Bertok M., Budihna N. and Povž M., 2003. Strokovne osnove za vzpostavljanje omrežja Natura 2000: ribe (pisces), piškurji (Cyclostomata), raki deseteronožci (Decapoda): Konažno poročilo. Naročnik: Ministarstvo za okolje, protor in energijo, ARSO. Zavod za ribištvo Slovenije, Ljubljana, 370 p. + digitaine priloge.

Bohman P., Nordwell F. and Edsman L., 2006. The effect of the large-scale introduction of signal crayfish on the spread of crayfish plague in Sweden. Bull. Fr. Pêche Piscic., 380-381, 1291-1302.

Bolea L., 1996. Primera cita de Cherax destructor (Crustacea: Decapoda: Parastacidae) en Europa. Bol. Soc. Entomol. Aragonesa (Zaragoza), 14, 49-51.

Borne M. von dem., 1906. Teichwirtschaft, 5te Auflage, Paul Parey, Berlin, 180 p.

Bramard M., Demers A., Trouilhé M.C., Bachelier E., Dumas J.C., Fournier C., Broussard E., Robin O., Souty-Grosset C. and Grandjean F., 2006. Distribution of indigenous and non-indigenous crayfish populations in the Poitou-Charentes Region (France): Evolution over the past 25 years. Bull. Fr. Pêche Piscic., 380-381, 857-865.

Burba A., 2008. Orconectes limosus found along the Lithuanian coastal zone of the Baltic Sea. Crayfish News: IAA Newsletter, 30, 2, 6-7.

Burba A., to appear. Spreading of invasive crayfish (Orconectes limosus) throughout Lithuanian waters. Freshwater Crayfish.

Camargo J.A. and Gonzalo C., 2009. Non-indigenous crayfish in Spain: An overview. In: Kozák P. and Kouba A. (eds.), Abstract Book, Future of Native Crayfish in Europe, Regional European Crayfish Workshop: 7th-10th September 2009, Písek, Czech Republic, 43-44.

Capurro M., Galli L., Mori M., Salvidio S. and Arillo A., 2007. The signal crayfish, Pacifastacus leniusculus (Dana, 1852) [Crustacea: Decapoda: Astacidae], in the Brugneto Lake (Liguria, NW Italy). The beginning of the invasion in the River Po watershed. Aquatic Invasions, 2, 1, 17-24. 
Carral J.M., Celada J.D., Gonzalez J.D., Saez-Royuela M., Gaudioso V.R., Fernandez R. and LopezBaisson C., 1993. Wild freshwater crayfish populations in Spain: current status and perspectives. Freshwater Crayfish, 9, 158-162.

Cerenius L. and Söderhäll K., 1992. Crayfish diseases and crayfish as vectors for important disease. Finn. Fish. Res., 14, 125-133.

Changeux T., 2003. Évolution de la répartition des écrevisses en France métropolitaine selon les enquêtes nationales menées par le Conseil Supérieur de la Pêche. Bull. Fr. Pêche Piscic., 370-371, $17-41$.

Chiesa S., Sciali M. and Gibertini G., 2006. Occurrence of allochthonous frehwater crayfishes in Latium (central Italy). Bull. Fr. Pêche Piscic., 380-381, 883-902.

Chucholl C., 2009. The 'newcomer' Orconectes immunis keeps spreading in the upper Rhine plain. Crayfish News: IAA Newsletter, 31, 3, 4-5.

Chucholl C. and Daudey T., 2008. First record of Orconectes juvenilis (Hagen 1870) in eastern France: update to the species identity of a recently introduced orconectid crayfish (Crustacea: Astacida). Aquatic Invasions, 3, 1, 105-107.

Chucholl C., Stich H.B. and Maier G., 2008. Aggressive interactions and competition for shelter between a recently introduced and an established invasive crayfish: Orconectes immunis vs. O. limosus. Fund. Appl. Limnol., 172, 1, 27-36.

Collas M., Julien C. and Monnier D., 2007. La situation en France résultats des enquêtes nationales réalisées entre 1877 et 2006 par le Conseil Supérieur de la Pêche. Bull. Fr. Pêche Piscic., 386, $1-38$.

Collins V., 2006. $£ 100000$ battle against alien crayfish ends in defeat. Crayfish News: IAA Newsletter, $28,1,10-11$.

D’Agaro E., De Luise G. and Lanari D., 1999. The current status of crayfish farming in Italy. Freshwater Crayfish, 12, 506-517.

DAISIE, 2009. Handbook of Alien Species in Europe, Springer, Dordrecht.

Dehus P., Dussling U. and Hoffmann C., 1999. Notes on the occurrence of the calico crayfish (Orconectes immunis) in Germany. Freshwater Crayfish, 12, 786-790.

Diéguez-Uribeondo J., 2006a. The dispersion of the Aphanomyces astaci-carrier Pacifastacus leniusculus by humans represents the main cause of disappearance of the indigenous crayfish Austropotamobius pallipes in Navarra. Bull. Fr. Pêche Piscic., 380-381, 1303-1312.

Diéguez-Uribeondo J., 2006b. Pathogens, parasites and ectocommensals. In: Souty-Grosset C., Holdich D.M., Noël P.Y., Reynolds J.D. and Haffner P. (eds.), Atlas of Crayfish in Europe, Muséum national d'Histoire naturelle, Paris, Patrimoines naturels, 64, 133-149.

Diéguez-Uribeondo J. and Söderhäll K., 1993. Procambarus clarkii Girard as a vector for the crayfish plague fungus, Aphanomyces astaci Schikora. Aqua. Fish. Manag., 24, 761-765.

Diéguez-Uribeondo J., Royo F., Souty-Grosset C., Ropiquet A. and Grandjean F., 2008. Low genetic variability of the white-clawed crayfish in the lberian Peninsula: its origin and management implications. Aquat. Conserv., 18, 1, 19-31.

Diéguez-Uribeondo J., García M.A., Cerenius L., Kozubíková E., Ballesteros I., Windels C., Weiland J., Kator H., Söderhäll K. and Martín M.P., 2009. Phylogenetic relationships among plant and animal parasites, and saprotrophs in Aphanomyces (Oomycetes). Fungal Genet. Biol., 46, 365-376.

Dubois J.-P., Gillet C. and Michoud M., 2006. Extension d'une espèce envahissante : suivi de la population d'écrevisses signal (Pacifastacus leniusculus Dana) au Léman à l'ouest de Thonon-les-Bains, entre 2001 et 2005 - impact de la pêche. Bull. Fr. Pêche Piscic., 382, 45-56.

Dunn J.C., McClymont H.E., Christmas M. and Dunn A.M., 2009. Competition and parasitism in the native white-clawed crayfish Austropotamobius pallipes (Lereboullet) and the invasive signal crayfish Pacifastacus leniusculus (Dana) in the UK. Biol. Inv., 11, 2, 315-324.

Edgerton B.F., Henttonen P., Jussila J., Mannonen A., Paasonen P., Taugbøl T., Edsman L. and SoutyGrosset C., 2004. Understanding the causes of disease in European freshwater crayfish. Conserv. Biol., 18, 1466-1474.

Edsman L., 2004. The Swedish story about import of live crayfish. Bull. Fr. Pêche Piscic., 372-373, 281-288.

Edsman L. and Schröder S., 2009. Åtgärdsprogram för Flodkräfta 2008-2013 (Astacus astacus), Fiskerivertet och Naturvårdsverket, Rap. 5955, 67 p. 
Edsman L. and Śmietana P., 2004. Roundtable 2. Exploitation, conservation and legislation. Bull. Fr. Pêche Piscic., 372-373, 457-464.

Ellis A., 2009. Non-native invasive crayfish within the Thames Basin, Environment Agency internal report, Thames Region, London, $51 \mathrm{p}$.

Environment Agency, 2007. News release, October 2007, RP/PR240/07/E.

Environment News Service, 2008. UK Invasive Species Strategy Attracts Public Support, Internet publication, http://www.ens-newswire.com/ens/an2008/2008-01-04-02.asp [accessed June 2009].

European Commission (EC), 2008. Towards an EU strategy on invasive species, (COM/2008) 789, 68 p.

Faller M., Hudina S., Klobučar G. and Maguire I., 2009. Spread of invasive spiny-cheek crayfish (Orconectes limosus) in Croatia: filling knowledge gaps and identifying confinement measures. In: Kozák P. and Kouba A. (eds.), Abstract Book, Future of Native Crayfish in Europe, Regional European Crayfish Workshop, 7th-10th September 2009, Písek, 17.

Fea G., Nardi P.A., Ghia D., Spairani M., Manenti R., Rossi S., Moroni M. and Bernini F., 2006. Dati preliminari sulla distribuzione in Lombardia dei gamberi d'acqua dolce autoctoni e alloctoni. Atti. Soc. it. Sci. nat. Museo civ. Stor. nat. Milano, 147, II, 201-210.

Ferri M., Gianaroli M. and Sala L., 2006. Diffusione del gambero rosso della Luisiana (Procambarus clarkii) in Provincia di Modena. J. Fresh. Biol., 34, 1-6.

Filipová L., Kozubíková E. and Petrusek A., 2006a. Orconectes limosus (Rafinesque, 1817). In: Mlíkovský J. and Stýblo P. (eds.), Nepưvodní druhy ve fauně a flóře České republiky [Alien species in fauna and flora of the Czech Republic], ČSOP, Praha, 237-239.

Filipová L., Petrusek A., Kozák P. and Policar T., 2006b. Pacifastacus leniusculus (Dana, 1852). In: Mlíkovský J. and Stýblo P. (eds.), Nepưvodní druhy ve fauně a flóře České republiky [Alien species in fauna and flora of the Czech Republic], ČsOP, Praha, 239-240.

Filipová L., Holdich D.M., Grandjean F. and Petrusek A., 2009. Cryptic diversity within the invasive virile crayfish Orconectes virilis (Hagen, 1870) species complex: new lineages recorded in both native and introduced ranges. Biol. Inv., DOI 10.1007/s10530-009-9526-0.

Fratini S., Zaccara S., Barbaresi S., Grandjean F., Souty-Grosset C., Crosa G. and Gherardi F., 2005. Phylogeography of the threatened crayfish (genus Austropotamobius) in Italy: implications for its taxonomy and conservation. Heredity, 94, 1, 108-118.

Füreder L. (ed.), 2009. Flusskrebse, Biologie - Ökologie - Gefahrdung, Veroffentlichungen des Naturmuseums Sudtirol, 6, 144 p.

Füreder L. and Machino Y., 1999. Les écrevisses exotiques dans le Tyrol du Sud (Italie). L'Astaciculteur de France, 61, 2-6.

Füreder L., Oberkofler B., Hanel R., Leiter J. and Thaler B., 2003. The freshwater crayfish Austropotamobius pallipes in South Tyrol: heritage species and bioindicator. Bull. Fr. Pêche Piscic., 370-371, 79-95.

Füreder L., Weinländer M. And Perlinger H., 2009. Die flusskrebse Österreichs. In: Füreder L. (ed.), Flusskrebse, Biologie - Ökologie - Gefahrdung, Veroffentlichungen des Naturmuseums Sudtirol, 6, 82-91.

Gallagher M.B., Dick J.T.A. and Elwood R.W., 2005. Riverine habitat requirements of the white-clawed crayfish, Austropotamobius pallipes. Biol. Environ., 106, 1-8.

Gelmar C., Pätzold F., Grabow K. and Martens A., 2006. Der Kalikokrebs Orconectes immunis am nördlichen Oberrhein: ein neuer amerikanischer Flusskrebses breitet sich rasch in Mitteleuropa aus (Crustacea: Cambaridae). Lauterbornia, 56, 15-25.

Genovesi P., 2007. Toward a European strategy to halt biological invasions in inland waters. In: Gherardi F. (ed.), Biological invaders in inland waters: profiles, distribution, and threats, Invading Nature: Springer Series in Invasion Ecology, Springer, Dordrecht, 507-542.

Gherardi F., 2006. Crayfish invading Europe: the case study of Procambarus clarkii. Mar. Freshwater Behav. Physiol., 39, 3, 175-191.

Gherardi F., 2007. Understanding the impact of invasive crayfish. In: Gherardi F. (ed.), Biological invaders in inland waters: profiles, distribution, and threats, Invading Nature: Springer Series in Invasion Ecology, Springer, Dordrecht, 507-542.

Gherardi F. and Acquistapace P., 2007. Invasive crayfish in Europe: the impact of Procambarus clarkii on the littoral community of a Mediterranean lake. Freshwat. Biol., 52, 7, 1249-1259. 
Gherardi F. and Lazzara L., 2006. Effects of the density of an invasive crayfish (Procambarus clarkii) on pelagic and surface microalgae in a Mediterranean wetland. Arch. Hydrobiol., 165, 3, 401-414.

Gherardi F., Aquiloni L., Tricarico E. and Morpurgo M., 2009. Süsswasserkrebse in Italien. In: Füreder L. (ed.), Flusskrebse, Biologie - Ökologie - Gefahrdung, Veroffentlichungen des Naturmuseums Sudtirol, 6, 53-65.

Gibson F.A., 1979. An international code of practice and the Irish regulations relating to certain aquatic organisms. In: Kernan R.P., Mooney O.V. and Went A.E.J. (eds.), The introduction of exotic species, advantages and problems, Royal Irish Academy, Dublin, 69-72.

Gil-Sanchez J.-M. and Alba-Tercedor J., 2006. The decline of the endangered populations of native freshwater crayfish (Austropotamobius pallipes) in southern Spain: is it possible to avoid extinction? Hydrobiologia, 559, 113-122.

Gladman Z., Adams C., Bean C., Sinclair C. and Yeomans W., 2009. Signal crayfish in Scotland. In: Brickland J., Holdich D.M. and Imhoff E.M. (eds.), Crayfish conservation in the British Isles, Proceedings of conference held in Leeds, 43-48.

Gouin N.F., Grandjean F., Pain S., Souty-Grosset J. and Reynolds J., 2003. Origin and colonization history of the white-clawed crayfish, Austropotamobius pallipes, in Ireland. Heredity, 9, 1, 70-77.

Govedič M., 2003. Potočni raki Slovenije, Center za kartografijo favne in flore, Miklavž na Dravskem polju, $14 \mathrm{p}$.

Grandjean F., Gouin N., Souty-Grosset C. and Diéguez-Uribeondo J., 2001. Drastic bottlenecks in the endangered crayfish species Austropotamobius pallipes in Spain, and implications for its colonization history. Heredity, 86, 431-438.

Guan R.-Z., 1994. Burrowing behaviour of signal crayfish, Pacifastacus leniusculus (Dana), in the River Great Ouse, England. Freshwater Forum, 4, 155-168.

Guan R.-Z. and Wiles P.R., 1996. Growth, density and biomass of crayfish, Pacifastacus leniusculus, in a British lowland river. Aquat. Living Resour., 9, 265-272.

Guan R.-Z. and Wiles P.R., 1997. Ecological impact of introduced crayfish on benthic fishes in a British lowland river. Conserv. Biol., 11, 3, 641-647.

Habsburgo-Lorena A.S., 1979. Present situation of exotic species of crayfish introduced into Spanish continental waters. Freshwater Crayfish, 4, 175-184.

Harlioğlu M.M., 2007. A new record of recently discovered crayfish, Austropotamobius torrentium (Shrank, 1803), in Turkey. Bull. Fr. Pêche Piscic., 387, 1-5.

Harlioğlu M.M., 2008. The harvest of the freshwater crayfish Astacus leptodactylus Eschscholtz in Turkey: harvest history, impact of crayfish plague, and present distribution of harvested populations. Aquacult. Int., 16, 351-360.

Hefti D. and Stucki P., 2006. Crayfish management for Swiss waters. Bull. Fr. Pêche Piscic., 380-381, 937-950.

Heinimaa S. and Pursiainen M., 2008. Signal crayfish Pacifastacus leniusculus at northerly latitudes: a search for the distribution limits. Freshwater Crayfish, 16, 37-41.

Henttonen P. and Huner J.V., 1999. The introduction of alien species of crayfish in Europe: A historical introduction. In: Gherardi F. and Holdich D.M. (eds.), Crayfish in Europe as alien species - how to make the best of a bad situation?, A.A. Balkema, Rotterdam, 13-22.

Hirsch P., 2009. Freshwater crayfish invasions: a former crayfish invader Galician crayfish hands title "invasive" over to new invader spiny-cheek crayfish. Biol. Inv., 11, 3, 515-521.

Hirsch P.E. and Fischer P., 2008. Interactions between native juvenile burbot (Lota lota) and the invasive spinycheek crayfish (Orconectes limosus) in a large European lake. Can. J. Fish. Aquat. Sci., 65, 2636-2643.

Holdich D.M., 1999. The negative effects of established crayfish introductions. In: Gherardi F. and Holdich D.M. (eds.), Crayfish in Europe as alien species - how to make the best of a bad situation?, A.A. Balkema, Rotterdam, 31-47.

Holdich D.M., 2002. Distribution of crayfish in Europe and some adjoining countries. Bull. Fr. Pêche Piscic., 367, 611-650.

Holdich D.M., 2003. Crayfish in Europe - an overview of taxonomy, legislation, distribution, and crayfish plague outbreaks. In: Holdich D.M. and Sibley P.J. (eds.), Management \& Conservation of Crayfish, Proceedings of a conference held in Nottingham on 7th November 2002, Environment Agency, Bristol, 15-34. 
Holdich D. and Black J., 2007. The spiny-cheek crayfish, Orconectes limosus (Rafinesque, 1817) [Crustacea: Decapoda: Cambaridae], digs into the UK. Aquatic Invasions, 2, 1, 1-16.

Holdich D.M. and Pöckl M., 2005. Does legislation work in protecting vulnerable species? Bull. Fr. Pêche Piscic., 376-377, 809-827.

Holdich D.M. and Pöckl M., 2007. Invasive crustaceans in European inland waters. In: Gherardi F. (ed.), Biological invaders in inland waters: profiles, distribution and threats, Springer, The Netherlands, $29-75$.

Holdich D.M. and Sibley P.J., 2009. ICS and NICS in Britain in the 2000s. In: Brickland J., Holdich D.M. and Imhoff E.M. (eds.), Crayfish Conservation in the British Isles, Proceedings of conference held in Leeds, 13-33.

Holdich D.M., Rogers W.D. and Reader J.P., 1995. Crayfish conservation, Project Record 378/10/N\&Y, National Rivers Authority, Bristol.

Holdich D.M., Gydemo R. and Rogers W.D., 1999. A review of possible methods for controlling alien crayfish populations. In: Gherardi F. and Holdich D.M. (eds.), Crayfish in Europe as alien species how to make the best of a bad situation?, A.A. Balkema, Rotterdam, 245-270.

Holdich D.M., Rogers W.D. and Reynolds J.D., 1999. Native and alien crayfish in the British Isles. In: Gherardi F. and Holdich D.M. (eds.), Crayfish in Europe as alien species, how to make the best of a bad situation?, A.A. Balkema, Rotterdam, 221-235.

Holdich D., Sibley P. and Peay S., 2004. The white-clawed crayfish - a decade on. British Wildlife, 15, 3, 153-164.

Holdich D.M., Haffner P. and Noël P., 2006. Species files. In: Souty-Grosset C., Holdich D.M., Noël P.Y., Reynolds J.D. and Haffner P. (eds.), Atlas of Crayfish in Europe, Muséum national d'Histoire naturelle, Paris, Patrimoines naturels, 64, 50-129.

Holdich D.M., Palmer M. and Sibley P.J., 2009. The indigenous status of Austropotamobius pallipes (Lereboullet) in Britain. In: Brickland J., Holdich D.M. and Imhoff E.M. (eds.), Crayfish Conservation in the British Isles, Proceedings of conference held in Leeds, 1-11.

Horton M.P., 2009. Establishing the island of Ireland's first ark site for the white-clawed crayfish Austropotamobius pallipes in the Ballinderry river system, Co. Tyrone. In: Brickland J., Holdich D.M. and Imhoff E.M. (eds.), Crayfish Conservation in the British Isles, Proceedings of conference held in Leeds, 87-94.

Hudina S. and Lucić A., 2009. Distribution and dispersal of signal crayfish (Pacifastacus leniusculus) in river Mura. In: Kozák P. and Kouba A. (eds.), Abstract Book, Future of Native Crayfish in Europe, Regional European Crayfish Workshop, 7th-10th September 2009, Písek, 46.

Hulme P.E., Pysek P., Nentwig W. and Vilà M., 2009. Will threat of biological invasions unite the European Union? Science, 324, 40-41.

Huner J.V., 2002. Procambarus. In: Holdich D.M. (ed.), Biology of Freshwater Crayfish, Blackwell Science, Oxford, 541-584.

Ibrahim A.M., Magdy T.K. and Murbarak M.F., 1997. Ecological studies on the exotic crayfishes, Procambarus clarkii and Procambarus zonangulus in the River Nile, Egypt. Int. J. Ecol. Environ. Sci., 23, 217-228.

IUCN, 2001. IUCN Red List Categories and Criteria Version 3.1, IUCN Species Survival Commission, IUCN, Gland, Cambridge.

IUCN, 2003. Guidelines for Application of IUCN Red List Criteria at Regional Levels, Version 3.0, IUCN Species Survival Commission, IUCN, Gland, Cambridge.

IUCN, 2009. IUCN Red List of Threatened Species Version 2009. 1, www.iucnredlist.org [accessed 6 September 2009].

Jansky V. and Kautman J., 2007. Americky rak Orconectes limosus (Crustacea: Decapoda: Cambaridae) už aj na Slovensku. Acta Rer. Natur. Mus. Nat. Slov., LIII, 21-25.

Johnsen S.I. and Vrålstad T., 2009. Signal crayfish and crayfish plague in the Halden watercourse proposition for a measurement plan, NINA Report 474, 29 p. [in Norwegian].

Johnsen S.I., Taugbøl T., Andersen O., Museth J. and Vrålstad T., 2007. The first record of the nonindigenous signal crayfish Pacifastacus leniusculus in Norway. Biol. Invasions, 9, 939-941.

Jones J.P.G., Rasamy J.R., Harvey A., Toon A., Oidtmann B., Randrianarison M.H., Raminosoa N. and Ravoahangimalala O.R., 2009. The perfect invader: a parthenogenic crayfish poses a new threat to Madagascar's freshwater biodiversity. Biol. Invasions, 11, 1475-1482. 
Jussila J. and Mannonen A., 2004. Crayfisheries in Finland, a short overview. Bull. Fr. Pêche Piscic., 372-373, 263-273.

Karaman I. and Machino Y., 2004. Occurrence of the spiny-cheek crayfish (Orconectes limosus) and the Chinese mitten crab (Eriocheir sinensis) in Serbia. Crayfish News: IAA Newsletter, 26, 2, 11-19.

Keller M. and Stucki T., 2008. Der Kamberkrebs, Orconectes limosus Rafinesque, 1817. Forum flusskrebse, 9, 3-26.

Kindemba V. and Whitehouse A., 2009. Using GIS to identify and prioritize regional ark sites for whiteclawed crayfish: aggregate and mineral extraction sites in South-west England. In: Brickland J., Holdich D.M. and Imhoff E.M. (eds.), Crayfish Conservation in the British Isles, Proceedings of conference held in Leeds (in press).

Kiszely P., 2006. Present status of crayfish in west Hungary. Crayfish News: IAA Newsletter, 28, 2, 1-3.

Koese B. and Blokland A., 2008. Gestreepte ontmoet Rode én Geknobbelde. European Invertebrate Survey. Kreeften nieuwsbrief, 2, November 2008, 2-6.

Kozák P., Adámek Z. and Řehulka J., 2000a. Crayfish plague outbreak in Pšovka brook in 1998. Bulletin VÚRH Vodňany, 36, 41-46 [in Czech].

Kozák P., Červinka S. and Vladík P., 2000b. Mass mortality of noble crayfish in Loděnice Brook in 1999. Bulletin VÚRH Vodňany, 36, 47-51 [in Czech].

Kozák P., Ďuriš Z. and Policar T., 2002. The stone crayfish Austropotamobius torrentium (Schrank) in the Czech Republic. Bull. Fr. Pêche Piscic., 367, 707-713.

Kozák P., Policar T. and Ďuriš Z., 2004. Migratory ability of Orconectes limosus through a fishpass and notes on its occurrence in the Czech republic. Bull. Fr. Pêche Piscic., 372-373, 37-373.

Kozubíková E., Petrusek A., Duuriš Z., Kozák P., Geiger S., Hoffmann R. and Oidtmann B., 2006. The crayfish plague in the Czech Republic - review of recent suspect cases and a pilot detection study. Bull. Fr. Pêche Piscic., 380-381, 1313-1323.

Kozubíková E., Petrusek A., Ďuriš Z. and Oidtmann B., 2007. Aphanomyces astaci, the crayfish plague pathogen, may be a common cause of crayfish mass mortalities in the Czech Republic. Bull. Eur. Assoc. Fish Pathol. , 27, 79-82.

Kozubíková E., Petrusek A., Ďuriš Z, Martín M.P., Diéguez-Uribeondo J. and Oidtmann B., 2008. The old menace is back: Recent crayfish plague outbreaks in the Czech Republic. Aquaculture, 274, 2-4, 208-217.

Kozubíková E., Filipová L., Kozák P., Ďuriš Z., Martín M.P., Diéguez-Uribeondo J., Oidtmann B. and Petrusek A., 2009. Prevalence of the crayfish plague pathogen Aphanomyces astaci in invasive American crayfishes in the Czech Republic. Conserv. Biol., 23, 1204-1213.

Krzywosz T. and Ulikowski D., 2009. Unknown causes a sharp decline in population of spiny-cheek crayfish Orconectes limosus (Rafinesque). In: Kozák P. and Kouba A. (eds.), Abstract Book, Future of Native Crayfish in Europe, Regional European Crayfish Workshop, 7th-10th September 2009, Písek, 25.

Lerat D., Paris L. and Baran P., 2006. Statut de l'écrevisses à pattes blanches (Austropotamobius pallipes Lereboullet, 1858) en Bourgogne : bilan de 5 années de propection. Bull. Fr. Pêche Piscic., 380-381, 867-882.

Ligas A., 2008. Population dynamics of Procambarus clarkii (Girard, 1852) (Decapoda, Astacidea, Cambaridae) from Southern Tuscany (Italy). Crustaceana, 81, 5, 601-609.

Lindqvist O.V. and Huner J.V., 1999. Life history characteristics of crayfish: What makes them good colonizers? In: Gherardi F. and Holdich D.M. (eds.), Crayfish in Europe as alien species - how to make the best of a bad situation?, A.A. Balkema, Rotterdam, 23-30.

Lodge D.M., Taylor C.A., Holdich D.M. and Skurdal J., 2000. Nonindigenous crayfishes threaten North American freshwater biodiversity. Fisheries, 25, 8, 7-20.

Lowe S., Browne M., Boudjelas S. and De Poorter M., 2000. 100 of the world's worst invasive alien species. A selection from the Global Invasive Species Database. Aliens, 12, 1-12 (http://www. issg.org/).

Machino Y., 1997. Présence de l'écrevisse de Californie (Pacifastacus leniusculus) en Italie. L'Astaciculteur de France, 52, 2-5.

Machino Y. and Holdich D.M., 2006. Distribution of crayfish in Europe and adjacent countries: updates and comments. Freshwater Crayfish, 15, 292-323. 
Machino Y., Füreder L., Laurent P.J. and Petutchnig J., 2004. Introduction of the white-clawed crayfish Austropotamobius pallipes in Europe. Ber. Nat.-med. Verein Innsbruck, 91, 187-212.

Maguire I., 2009. Die flusskrebse Osteuropas. In: Füreder L. (ed.), Flusskrebse, Biologie - Ökologie Gefahrdung, Veroffentlichungen des Naturmuseums Sudtirol, 6, 92-97.

Maguire I. and Klobučar G., 2003. Appearance of Orconectes limosus in Croatia. Crayfish News: IAA Newsletter, 25, 3, 7.

Maguire I., Klobučar G., Marčić Z. and Zanella D., 2008. The first record of Pacifastacus leniusculus in Croatia. Crayfish News: IAA Newsletter, 30, 4, 4.

Maitland P.S., 1996. The North American signal crayfish, Pacifastacus leniusculus (Dana), established in the wild in Scotland. Aquat. Conserv., 6, 2, 107-110.

Manganelli G., Favilli L. and Fiorentino V., 2006. Taxonomy and nomenclature of Italian white-clawed crayfish. Crustaceana, 79, 5, 633-640.

Marten M., Werth C. and Marten D., 2004. Der Marmorkrebs Procambarus sp. (Cambaridae, Decapoda) in Deutschland - ein weitreres Neozoon in Rheineinzugsgebeit. Lauterbonia, 50, 17-23.

Martinez R., Rico E. and Alonso F., 2003. Characterization of Austropotamobius italicus (Faxon, 1914) in a central Spain area. Bull. Fr. Pêche Piscic., 370-371, 43-56.

Marzano F.N., Scalici M., Chiesa S., Gherardi F., Piccinini A. and Gilbertini G., 2009. The first record of the marbled crayfish adds further threats to freshwaters in Italy. Aquatic Invasions, 4, 2, 401-404.

Nardi P.A., Bernini F., Bo T., Bonardi A., Fea G., Ghia D., Negri A., Razzetti E., Rossi S. and Spairani M., 2005. Status of Austropotamobius pallipes complex in the watercourses of the Alessandria province (N-W Italy). Bull. Fr. Pêche Piscic., 376-377, 585-598.

Neveu A. and Bachelier E., 2002. Mortalité d'Austropotamobius pallipes sur le bassin de la Sèvre Niortaise. Présence de l'aphanomycose. L'Astaciculteur de France, 76, 2-4.

Nightingale J., Clarkson M., Frayling M., Robbins L., Sibley P. and Stenson C., 2009. South West Whiteclawed Crayfish Conservation Strategy 2008-2012, Bristol Zoo, Bristol, 4 p.

Oidtmann B., 2000. Diseases in freshwater crayfish. In: Rogers D. andBrickland J. (eds.), Crayfish Conference Leeds, Environment Agency, 9-18.

Oidtmann B., Schaefer N., Cerenius L., Söderhäll K. and Hoffmann R.W., 2004. Detection of genomic DNA of the crayfish plague fungus Aphanomyces astaci (Oomycete) in clinical samples by PCR. Vet. Microbiol., 100, 3-4, 269-282.

Paaver T. and Hurt M., 2009a. Status and management of noble crayfish Astacus astacus in Estonia. In: Kozák P. and Kouba A. (eds.), Abstract Book, Future of Native Crayfish in Europe, Regional European Crayfish Workshop, 7th-10th September 2009, Písek, 49.

Paaver T. and Hurt M., 2009b. Do we have any real chance to protect noble crayfish from plague and alien species? Experience of Estonia. In: Kozák P. and Kouba A. (eds.), Abstract Book, Future of Native Crayfish in Europe, Regional European Crayfish Workshop, 7th-10th September 2009, Písek, 31.

Pârvulescu L., Paloş C. and Molnar P., 2009. First record of the spiny-cheek crayfish Orconectes limosus (Rafinesque, 1817) (Crustacea: Decapoda: Cambaridae) in Romania. North-West J. Zool., 5, 2, 424-428.

Pavolić S., Milošević S., Borković S., Simić V., Paunović M., Žikić R. and Saičić Z., 2006. A report of Orconectes (Faxonius) limosus (Rafinesque, 1817) [Crustacea: Decapoda: Astacidae: Cambaridae:Orconectes: subgenus Faxonius] in the Serbian part of the River Danube. Biotechnol. Biotechno., 20, 53-56.

Peay S., 2009. Selection criteria for "ark sites" for white-clawed crayfish. In: Brickland J., Holdich D.M. and Imhoff E.M. (eds.), Crayfish Conservation in the British Isles, Proceedings of conference held in Leeds, 63-69.

Peay S., Hiley P.D., Collen P. and Martin I., 2006. Biocide treatment of ponds in Scotland to eradicate signal crayfish. Bull. Fr. Pêche Piscic., 380-381, 1363-1379.

Peay S., Holdich D.M. and Brickland J., to appear. Risk assessments of non-indigenous crayfish in Great Britain. Freshwater Crayfish.

Perdikaris C., Koutrakis E., Saraglidou V. and Margaris N., 2007. Confirmation of occurrence of the narrow-clawed crayfish Astacus leptodactylus Eschscholtz, 1823 in the River Evros in Greece. Bull. Fr. Pêche Piscic., 385, 45-52. 
Petrusek A., 2009. Invasive crayfish in Central Europe: distribution and impact through pathogen transmission. Abstract, Habilitation thesis, Department of Ecology, Faculty of Science, Charles University in Prague, $104 \mathrm{p}$.

Petrusek A. and Petruskova T., 2007. Invasive American crayfish Pacifastacus leniusculus (Decapoda: Astacidae) in the Morava River (Slovakia). Biologie, Bratislava, 62, 3, 356-359.

Petrusek A., Filipová L., Ďuriš Z., Horká L., Kozák P., Policar T., Štambergova M. and Kučera Z., 2006. Distribution of the invasive spiny-cheek crayfish (Orconectes limosus) in the Czech Republic. Past and present. Bull. Fr. Pêche Piscic., 380-381, 903-918.

Petutschnig J., 2008. Der Rote Amerikanischer Sumpfkrebs (Procambarus clarkii) in Österreich. Forum flusskrebse, 10, 21-25.

Pöckl M., 1999. Distribution of crayfish in Austria with special reference to introduced species. Freshwater Crayfish, 12, 733-776.

Pöckl M. and Pekny R., 2002. Interaction between native and alien species of crayfish in Austria: case studies. Bull. Fr. Pêche Piscic., 367, 763-776.

Pöckl M., Holdich D.M. and Pennerstorfer J., 2006. Identifying native and alien crayfish species in Europe, European Project CRAYNET, Guglar Cross Media, Melk, Austria, 47 p.

Polloni G. and Ghezzi D., 2008. Osservazioni riguarddanti la presenza di Orconectes limosus (Rafinesque, 1817) e Procambarus clarkii (Girard, 1852) in provincial di Crimona. Scienze e storia dell'ambiente padano, 23, 113-120.

Pugh M., 2008. The River Stour crayfish survey 2007. Essex Nat. (NS), 25, 88-96.

Pugh M., lley M. and Bradley P., 2008. White-clawed crayfish Austropotamobius pallipes and non-native crayfish species in Essex rivers. Essex Nat. (NS), 25, 72-87.

Puky M., 2009. Confirmation of the presence of the spiny-cheek crayfish Orconectes limosus (Rafinesque, 1817) (Crustacea: Decapoda: Cambaridae) in Slovakia. N.-W. J. Zool., 5, 1, 214-217.

Puky M. and Schád P., 2006. Orconectes limosus colonises new areas fast along the Danube in Hungary. Bull. Fr. Pêche Piscic., 380-381, 919-926.

Puky M., Reynolds J.D. and Schad P., 2005. Native and alien Decapoda species in Hungary, distribution, status, conservation importance. Bull. Fr. Pêche Piscic., 376-377, 553-568.

Renai B., Bertocchi S., Brusconi S., Grandjean F., Lebboroni M., Parinet B., Souty-Grosset C., Trouilhè M.C. and Gherardi F., 2006. Ecological characterisation of streams in Tuscany for the management of the threatened crayfish Austropotamobius italicus. Bull. Fr. Pêche Piscic., 380-381, 1095-1114.

Renai B., Trouilhé M.C., Bourdon B., Bachelier E., Parinet B., Grandjean F. and Souty-Grosset C., 2008. Impact of heat wave on streams harbouring the white-clawed crayfish (Austropotamobius pallipes) in western France (Deux-Sèvres). Freshwater Crayfish, 16, 57-69.

Reynolds J.D., to appear. The current status of white-clawed crayfish in Ireland. In: Brickland J., Holdich D.M. and Imhoff E.M. (eds.), Crayfish Conservation in the British Isles, Proceedings of conference held in Leeds, March 2009.

Reynolds J.D., Celada J.D., Carral J.M. and Matthews M.A., 1992. Reproduction of astacid crayfish in captivity - current developments and implications for culture, with special reference to Ireland and Spain. Invertebr. Repr. Dev., 22, 253-266.

Reynolds J.D., Demers A. and Marnell F., 2002. Managing an abundant crayfish resource for conservation - A. pallipes in Ireland. Bull. Fr. Pêche Piscic., 367, 823-832.

Reynolds J., Demers A., Peay S., Puky M., Sibley P., Souty-Grosset C. and Taugbøl T., 2006. Crayfish conservation and management. In: Souty-Grosset C., Holdich D.M., Noël P.Y., Reynolds J.D. and Haffner P. (eds.), Atlas of Crayfish in Europe, Muséum national d'Histoire naturelle, Paris, Patrimoines naturels, 64, 152-157.

Rodriguez C.F., Becares E. and Fernandez-Alaez M., 2003. Shift from clear to turbid phase in Lake Chozas (NW Spain) due to the introduction of American red swamp crayfish (Procambarus clarkii). Hydrobiologia, 506, 421-426.

Rodriguez C.F., Becares E., Fernandez-Alaez M. and Fernandez-Alaez C., 2005. Loss of diversity and degradation of wetlands as a result of introducing exotic crayfish. Biol. Invasions, 7, 75-85.

Sallai Z. and Puky., 2008. A cifarák (Orconectes limosus) megjelenése a köpzép-Tisza-Vidékén. Acta Biol. Debr. Oecol. Hung., 18, 203-208.

Šanda R. and Petrusek A., 2009. Distribution and diversity of crayfishes in the Adriatic drainage of Bosnia and Herzegovina. In: Kozák P. and Kouba A. (eds.), Abstract Book, Future of Native Crayfish in Europe, Regional European Crayfish Workshop, 7th-10th September 2009, Písek, 50. 
Savvidis G., 2005a. Ekthesi-gnomatefsi epi tou fenomenou tou mazikou thanatou karavidon ston Potamo Kalama kai tous parapotamous tou Gormo kai Limpousda stin periohi Parakalamou tou $\mathrm{N}$. Ioanninon (Report on the massive mortalities incident in Kalamas River and its tributaries Gorno and Limpousda, Parakalamos, loannina Prefecture), Report n 1305/15-9-2005, National Agricultural Research Foundation, 11 p. [in Greek].

Savvidis G., 2005b. Simpliromatiki ekthesi epi tou fenomenou tou mazikou thanatou karavidon ston Potamo Kalama kai tous parapotamous tou Gormo kai Limpousda stin periohi Parakalamou tou $\mathrm{N}$. Ioanninon (Supplementary report on the massive mortalities incident in Kalamas River and its tributaries Gorno and Limpousda, Parakalamos, loannina Prefecture), Report n 1527/31-10-2005, National Agricultural Research Foundation, 3 p. [in Greek].

Scalici M. and Gherardi F., 2007. Structure and dynamics of an invasive population of the red swamp crayfish (Procambarus clarkii) in a Mediterranean wetland. Hydrobiologia, 583, 1, 309-319.

Scalici M., Belluscio A. and Gibertini G., 2008. Understanding population structure and dynamics in threatened crayfish. J. Zool., 275, 2, 160-171.

Scalici M., Chiesa S., Gherardi F., Ruffini M., Gilbertini G. and Marzano F.N., 2009. The new threat to Italian inland waters from the alien crayfish "gang": the Australian Cherax destructor Clark, 1936. Hydrobiologia, 632, 341-345.

Schulz H.K., Śmietana P. and Schulz R., 2002. Crayfish occurrence in relation to land-use properties: implementation of a Geographic Information System. Bull. Fr. Pêche Piscic., 367, 861-872.

Schulz H.K., Śmietana P., Maiwald T., Oidtmann B. and Schulz R., 2006. Case studies of the cooccurrence of Astacus astacus (L.) and Orconectes limosus (Raf.): snapshots of a slow displacement. Freshwater Crayfish, 15, 212-219.

Schulz H., Gross H., Dümpelmann C. and Schulz R., 2009. Flusskrebse Deutschlands. In: Füreder L. (ed.), Flusskrebse, Biologie - Ökologie - Gefahrdung, Veroffentlichungen des Naturmuseums Sudtirol, 6, 71-81.

Schulz R. and Śmietana P., 2001. Occurrence of native and introduced crayfish in northeastern Germany and northwestern Poland. Bull. Fr. Pêche Piscic., 361, 629-641.

Sibley P.J., 2003. The distribution of crayfish in Britain. In: Holdich D.M. and Sibley P.J. (eds.), Management and Conservation of Crayfish, Proceedings of a conference held on 7th November 2002, Environment Agency, Bristol, 64-72.

Sibley P.J., 2004. Conservation management and legislation. The UK experience. Bull. Fr. Pêche Piscic., 370-371, 209-217.

Sibley P., Clarkson M., Frayling M. and Stenson C., 2007. Translocating the white-clawed crayfish Austropotamobius pallipes. In: Hickley P. and Axford S. (eds.), Fisheries \& Conservation Successes \& Failures, Institute of Fisheries Management Conference Proceedings, 42-51.

Sibley P.J., Holdich D.M. and Lane M.-R., 2009. Invasive crayfish in Britain - management and mitigation. Int. Urban Ecol. Rev., 4, 105-118.

Simić V., Petrović A., Rajković M. and Paunović M., 2008. Crayfish of Serbia and Montenegro - the population status and the level of endangerment. Crustaceana, 81, 10, 1153-1176.

Skurdal J. and Taugbøl T., 2002. Astacus. In: Holdich DM (ed.), Biology of Freshwater Crayfish, Blackwell Science, Oxford, 467-510.

Śmietana P., Krzywosz T. and Strużyński., 2004. Review of the national restocking programme "Active Protection of native crayfish in Poland" 1999-2001. Bull. Fr. Pêche Piscic., 372-373, 289-299.

Śmietana P., Schulz H.K., Keszka S. and Schulz R., 2006. A proposal for accepting Pontastacus as a genus of European crayfish within the family Astacidae based on a revision of the west and east taxonomic literature. Bull. Fr. Pêche Piscic., 380-381, 1041-1052.

Soes D.M., 2008. Een vondst van de Australische roodklauwkreeft (Cherax quadricarinatus) in Nederland. European Invertebrate Survey. Kreeften nieuwsbrief, 2, 7-8.

Soes D.M. and Spier J.L., 2006. Onderzoek geknobbelde Amerikaanse rivierkreeft in de Kameriske Wetering e.o. Bureau Waaerenburg bv, Culemborg, $35 \mathrm{p}$.

Soes D.M. and van Eekelen R., 2006. Rivierkreeften een opruuend problem? De Levende Natuur, 107, 2, 56-59.

Souty-Grosset C., Holdich D.M., Noël P.Y., Reynolds J.D. and Haffner P. (eds.), 2006. Atlas of Crayfish in Europe, Muséum national d'Histoire naturelle, Paris, Patrimoines naturels, 64, $187 \mathrm{p}$. 
Stancliffe-Vaughan A., 2009. Non-native crayfish - a community research and trapping initiative on the River Lark, Suffolk. Crayfish News: IAA Newsletter, 31, 2, 5-7.

Starobogatov Ya.I., 1995. Taxonomy and geographical distribution of crayfishes of Asia and East Europe (Crustacea Decapoda Astacoidei). Arthropoda Selecta, 4, 3, 3-25.

Stephanou D., 1987. Cyprus Country Report for 1986-1987, 3 p., http://www.fao.org/docrep/005/ s7360b/S7360B02.htm [accessed 7 October 2009].

Stloukal E. and Harváneková M., 2005. Distribution of Austropotamobius torrentium (Decapoda: Astacidae) in Slovakia. Bull. Fr. Pêche Piscic., 376-377, 547-552.

Stloukal E. and Vitázková B., 2009. Recent situation of invasive and native crayfish species in Slovakia. In: Kozák P. and Kouba A. (eds.), Abstract Book, Future of Native Crayfish in Europe, Regional European Crayfish Workshop, 7th-10th September 2009, Písek, 53.

Strasser T. and Patzner R.A., 2005. Aquatische Neozoen im Stadtbereich, am Beispiel der Stadt Salzburg. Mitt. Zool. Ges. Braunau, 9, 1, 1-17.

Stucki P., Zaugg B., Büttiker B., Hefti D., Kugler M., Marchesi P., Stucki T. and Wicky J.D., 2005. Plan d'action national pour les écrevisses. Rapport OFEV, $41 \mathrm{p}$.

Stucki T. and Jean-Richard P., 2000. Verbreitung der Flusskrebse in der Schweiz. Mitteilungen zur Fischerei, 65, p. 52.

Stucki T., Hefti D. and Jean-Richard P., 2009. Die situation der flusskrebsbestände in der Schweiz. In: Füreder L. (ed.), Flusskrebse, Biologie - Ökologie - Gefahrdung, Veroffentlichungen des Naturmuseums Sudtirol, 6, 66-70.

Susloparova O. and Mitskevich O., 2009. Astacus astacus distribution and stocks in the Northwest of Russia waterbodies. In: Kozák P. and Kouba A. (eds.), Abstract Book, Future of Native Crayfish in Europe, Regional European Crayfish Workshop, 7th-10th September 2009, Písek, 34.

Swahn J.-Ö., 2004. The cultural history of crayfish. Bull. Fr. Pêche Piscic., 372-373, 243-251.

Taugbøl T., 2004. Exploitation is a prerequisite for conservation of Astacus astacus. Bull. Fr. Pêche Piscic., 372-373, 275-279.

Taugbøl T. and Skurdal J., 1999. The future of crayfish in Europe: How to make the best of a bad situation? In: Gherardi F. and Holdich D.M. (eds.), Crayfish in Europe as alien species - how to make the best of a bad situation?, A.A. Balkema, Rotterdam, 271-279.

Taugbøl T., Skurdal J. and Håstein T., 1993. Crayfish plague and management strategies in Norway. Biol. Cons., 63, 75-82.

Taugbøl T., Arens A. and Mitans A., 2004. Freshwater crayfish in Latvia: Status and recommendations for conservation and sustainable use. NINA Project Report, 29, 23 p.

Taylor C.A., 2002. Taxonomy and conservation of native crayfish stocks. In: Holdich D.M. (ed.), Biology of Freshwater Crayfish, Blackwell Science, Oxford, 236-257.

Taylor C.A., Schuster G.A., Cooper J.E., DiStephano R.J., Eversole A.G., Hamr P., Hobbs H.H. Jr., Robinson H.W., Skelton C.E. and Thoma R.F., 2007. A reassessment of the conservation status of crayfishes of the United States and Canada after 10+ years of increased awareness. Fisheries, 32 , 8, 372-389.

Tertyshny A.S. and Panchishny M.A., 2009. Use of effective microoroganisms against parasites and disease of narrow-clawed crayfish. In: Kozák P. and Kouba A. (eds.), Abstract Book, Future of Native Crayfish in Europe, Regional European Crayfish Workshop, 7th-10th September 2009, Písek, 42.

Theocharis V.S., 1986. La pêche à l'écrevisse dans la région d'Hipiros en Grèce. L'Astaciculteur de France, 8, 4-10.

Torre M. and Rodriguez P., 1964. El cangrejo de rio en Espana, Servicio national de pesca fluvial y caza, Ministeria de Agricultura, Madrid, 107 p.

Tricarico E., Vilizzi L., Gherardi F. and Copp G.H., 2010. Calibration of FI-ISK, an invasiveness screening tool for non-native freshwater invertebrates. Risk Analysis, 30, 2, 285-292.

Trontelj P., Machino Y. and Sket B., 2005. Phylogenetic and phylogeographic relationships in the crayfish genus Austropotamobius inferred from mitochondrial COI gene sequences. Mol. Phylogenet. Evol., 34, 212-226.

Troschel H.J., 1999. Distribution of crayfish species in Luxembourg. Freshwater Crayfish, 12, 791-795.

Unestam T., 1969. Resistance to the crayfish plague in some American, Japanese and European crayfishes. Rept. Inst. Freshwat. Res., Drottingholm, 49, 202-209. 
Unestam T., 1972. On the host range and origin of the plague fungus. Rept. Inst. Freshwat. Res., Drottingholm, 52, 192-198.

Unestam T. and Weiss D.W., 1970. Host-parasite relationship between freshwater crayfish and the crayfish disease fungus, Aphanomyces astaci. Responses to infection by a susceptible and a resistant species. J. Gen. Microbiol., 60, 77-90.

Vey A., Söderhäll K. and Ajaxon R., 1983. Susceptibility of Orconectes limosus Raf. to the Crayfish Plague, Aphanomyces astaci Schikora. Freshwater Crayfish, 5, 284-291.

Vigneux E., Thibault M., Marnell F. and Souty-Grosset C., 2002. Roundtable session 2A: National legislation, EU Directives and conservation. Bull. Fr. Pêche Piscic., 367, 887-898.

Vlach P., Fischer D. and Hulec L., 2009. The stone crayfish (Austropotamobius torrentium) in the Czech Republic. In: Kozák P. and Kouba A. (eds.), Abstract Book, Future of Native Crayfish in Europe, Regional European Crayfish Workshop, 7th-10th September 2009, Písek, 32.

Vogt G., 2008. The marbled crayfish: a new model organism for research and development, epigenetics and evolutionary biology. J. Zool., 276, 1, 1-13.

Weinländer M. and Füreder L., 2009. The continuing spread of Pacifastacus leniusculus in Carinthia (Austria): potential reasons, invasiveness and ecological effect. In: Kozák P. and Kouba A. (eds.), Abstract Book, Future of Native Crayfish in Europe, Regional European Crayfish Workshop, 7th-10th September 2009, Písek, 33.

Westman K., 1973. Cultivation of the American crayfish Pacifastacus leniusculus. Freshwater Crayfish, 1, 211-220.

Westman K., 2002. Alien crayfish in Europe: negative and positive impacts and interactions with native crayfish. In: Leppakowski E., Gollasch S. and Olenin S. (eds.), Invasive species of Europe: distribution, impacts and management, Kluwer Academic Publishers, Dordrecht, 76-95.

Westman K., Savolainen R. and Julkunen M., 2002. Replacement of the native crayfish Astacus astacus by the introduced species Pacifastacus leniusculus in a small, enclosed Finnish lake: a 30-year study. Ecography, 25, 53-73.

Wittenberg R. (ed.), 2005. An inventory of alien species and their threat to biodiversity and economy in Switzerland, CABI Bioscience Switzerland Centre report to the Swiss Agency for Environment, Forests and Landscape, p. 417.

Wizen G., Galil B.S., Shlagman A. and Gasith A., 2008. First record of red swamp crayfish, Procambarus clarkii (Girard, 1852) (Crustacea: Decapoda: Cambaridae) in Israel - too late to eradicate? Aquatic Invasions, 3, 2, 181-185.

Zaikov A. and Hubenova T., 2007. Status of freshwater crayfish in Bulgaria. Transactions of III International Conference "Fishery", 1-2 February 2007, Belgrade, 242-245. 